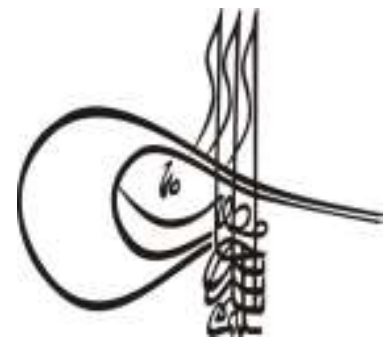

\section{Turkiglo Studies \\ Language and Literature \\ Volume 14 Issue 4, 2019, p. 2137-2218 \\ DOI: 10.29228/TurkishStudies.36829 \\ ISSN: 2667-5641 \\ Skopje/MACEDONIA-Ankara/TURKEY}

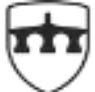

INTERNATIONAL

BALKAN

UNIVERSITY

EXCELLENCE FOR THE FUTURE IEU.EDU.MKK

Research Article / Araştırma Makalesi

Article Info/Makale Bilgisi

Received/Geliș: 31.08 .2019

\Accepted/Kabul: 20.12.2019

an Report Dates/Rapor Tarihleri: Referee 1 (13.09.2019)-Referee 2 (12.12.2019)

This article was checked by iThenticate.

\title{
NAMIK KEMAL'İN NAZİRELERİ ÜZERİNE BİR ARAŞTIRMA
}

\author{
Ahmet USLU*
}

\begin{abstract}
Öz
Tanzimat, Türk edebiyatında bir değișim ve dönüşümün yaşandığı dönüm noktalarından biridir. Bu değişimin öncülerinden olan Namık Kemal, arayışlar döneminin baş aktörlerindendir. "Vatan Şairi" olarak tanınan Namık Kemal, yazdığı divan şiirleri ile de döneminde adından söz ettiren etkin bir şairdir. Şiire nazirelerle başlayıp şairliğini nazirelere dayandırarak sürdürür ve ilkinden sonuncusuna kadar nazireciliği hiç terk etmez. Encümen-i Şuara topluluğunda yer alan şair gerek divan şairlerinin gerek encümen şairlerinin gerekse dönemin diğer şairlerinin siirlerine nazireler yazar. Namık Kemal nazirelerinde kuru bir taklitten çok şairliğini güçlendiren ve geliştiren bir yol izler. Birçok araştırmacı onun divan şiirleri üzerinde durmaz. Ancak taklit ya da başarısızlıkla nitelendirilen bu şiirler, onun "vatan şairi" olmasında önemli bir rol üstlenir. Nazire yazdığı şairlerde yenilik, farklılık ve söyleyiş ustalığı özelliklerini gözeten Namık Kemal, arayışlar dönemi olarak isimlendirilen dönemin örnek şairlerinden biri olmayı başarır. Bu çalışmada Namık Kemal divan şairi olarak ele alınarak fikrî alt yapısının ve şairliğinin gelişmesinde kendisine kaynak teşkil eden unsurlar üzerinde durulacaktır. Öncelikle encümen şairleri arasındaki yeri ortaya konularak nazire yazdığı tüm şiirler tek tek ele alınacaktır. Nazire yazılan şiir ile Namık Kemal'in şiiri karşılaştırılacak, klasik nazire anlayışından farkı ve yenilikler açıklanmaya çalışılacaktır. Bu karşılaştırmanın divan şiirinin geldiği noktayı ve değişimin nasıl gerçekleștiğini göstermesi bakımından dönemin aydınlatılmasına ve daha iyi anlaşılmasına katkı sunacağ1 kanaatindeyiz.
\end{abstract}

Anahtar Kelimeler: Namık Kemal, nazire, Tanzimat, Encümen-i Şuara. 


\title{
THE INVESTIGATION OF NAMIK KEMAL'S NAZIRES
}

\begin{abstract}
Tanzimat Reform Era is among the milestones of changes and conversion. Namik Kemal who is one of the pioneers of this conversion era, is one of the leading models of this period of pursuits. Namik Kemal, known as the "Vatan Şairi", is an influential poet who made a name for himself with his divan poems he wrote. He starts writing the poem through nazires, bases his poetry upon these nazires and also, he does never abandon the nazire writing. As a part of Encümen-i Şuara committee, Namik Kemal has written nazires for the poems of not only Ottoman poets and committee poets but also other poets of the period. In his nazires, Namik Kemal resorts to a method that develops his poesy, rather than apery. Many of the researchers do not dwell upon his Ottoman poetry. However, these poems that are described as apery and failure play an important role in him being a leader in national poetry. Namik Kemal, whose nazires have the features of novelty, dissimilarity and success in ways of expression, has been successful in becoming one of the prominent poets of the period called the period of pursuits. In the present study, Nam1k Kemal will be investigated with his Ottoman poetry and the sources that improves his literal background will be examined. First of all, the poems for which he has written the nazires will be analyzed by focusing on the place where he has been among the committee poets. Other poems and Namik Kemal's poems will be compared in terms of the nazire writing, what is different in his nazires from usual ones and the changes will be explained. This comparison is expected to shed light on the future research with respect to the current situation of Ottoman poetry and the changes that has happened to those poems.
\end{abstract}

\section{STRUCTURED ABSTRACT}

In this study, Namik Kemal, one of the leading poets of Tanzimat period, is considered as a divan poet. The poet, who wanted to portray Divan poetry with the Encümen-i Şuara poets, wrote poems for important poets of the past centuries as well as poets for poets of his time. The place of these nazires in the Divan poetry tradition, the success of the poet and the resurrection of the intended Divan poetry will be compared. This comparison will clarify how Namik Kemal, who pioneered the formation of new poetry, reached this accumulation. Divan poetry, in a sense, will lead to new research on how the accumulation influences the understanding of new poetry.

While examining the poems written by Namik Kemal, all the studies on this subject have been taken into consideration and the accuracy or the falsity of the criticisms towards his divan poems will be emphasized. In a sense, the study is an answer to the unfair criticism of the poems of Namik Kemal. 
Divan poetry is the most well-known method used by researchers in this field. In this study, we preferred to examine poems in a free form by going beyond the commentary tradition. In this preference, we want to know that our aim is not to explain poems but to reveal the contribution of poems to divan poetry. The main purpose of the study is what the poet paid attention to in his poems and his style and his contribution to his poetry.

19th century. It is a period of transition and quest for Turkish poetry. The loss of the old power of Divan poetry and the introduction of Western-style understanding by poets are the factors that accelerated this transition. Although the aim of Encümen-i Şuara poets to bring a new spirit to divan poetry and return it to its old days increased interest in divan poetry in this period, it does not continue in the face of new poetry style. Lesibofçalı Galib Bey, who is an important name in the gathering of Encümen poets and creating a taste of poetry, leads the other poets in reviving divan poetry. However, he cannot stay away from new style poetry and tries new styles in poetry. Namik Kemal, who read the poems of the Encümen poets in the community, was under the influence of Galib Bey of Leskofçali. He writes poems, especially his poems, to poets of his time and to poems of divan poets. He cannot make his own voice in the poems written by Namik Kemal in the style of divan poetry. The poems, which are usually composed of nazires, have little or no originality. However, these poems are not repetitive, numb, unsuccessful poems. It is a very important educational process for Namik Kemal's poems and understanding of poetry.

Namik Kemal's divan poems were ignored in the researches and generally new style poems were emphasized. In this study, although the poet's divan poems are not handled one by one, the situation of the poet in the divan poetry is tried to be put forward. Nazirism has an important place in Divan Literature tradition. A poet's reverence for other poets, approaching poets who have a lasting fame, the desire to be like poets whose style and style are admired, the interest in novelty poets, and the desire to be like poets, are effective in creating their own style. We see it as an injustice to the poet that Namık Kemal's divan-style poems are seen as imitations or criticism that most of the poems are composed of Nazirs. Namik Kemal writes poems in his poems that are able to capture the style and poetry of the poets he wrote to the poems, and even write poems that are successful enough to overcome them.

It is quite high that 183 of the 315 ghazals of Namik Kemal in total are Nazires. Among these poems, Leskofçalı Galib Bey's poems take the first place with a total of 52 nazires. After Galib Bey of Leskofçalı, Ârif Hikmet Bey of Hersek ranked second with the poems written in 32 poems. Considering the roles of these poets in the collection of the council and the pleasure of creating a poem, it is understandable that Namik Kemal wrote to these poets.

Poets who have found fame in the Divan poetry from the 16th century to the 19th century and whose name was mentioned with their style, especially masterful in harmony, attracted the attention of Namik Kemal. The desire to reconnect Divan poetry to the point where it came with Sheikh Galip increases the interest in this period. Namik Kemal prefers poets among these centuries, especially those who emphasize the 
elements of harmony, bring emphasis to thought and innovate poetry, and develop a unique style. Fuzuli, Şeyhülislam Yahya, Nedim, Naili, Fehim are known poets with these features. Namik Kemal's poetry to poets of these poets is also important in terms of showing the understanding of poetry. Both the council poets and the poet Namik Kemal wrote to these poets, the aim of this poet divan poetry aims to remove the point.

19th century. The common idea of poets is to raise Divan poetry again. In particular, committee meetings are held for this purpose. The attitude of Galib Bey in Leskofçalı and his understanding of poetry as an example to other poets is the most important function of the ensemble that survived for a short time. Among the poets of this period, Namik Kemal wrote the most poems to Galip Bey's poems. In these nazires, the poet takes important steps for the new poem. The relationship between lovers and lovers often divine love poet, $\mathrm{Hz}$. Moses and Tur Mountain event is very often given. The Tur Mountain incident, known as the time and place where God manifests on earth, is taken as a concrete indicator of God's existence. This point of view, in the Tanzimat period in the search for evidence of the existence of God and the mind is the basis of the prioritization of the ground.

Although Namik Kemal is one of the leading poets of the new poetry, he has a different place in divan poetry style. Although the poems he wrote could not take him too far to become a divan poet, he plays an important role in the formation of poetry aesthetics and perspectives. i Şuara.

Keywords: Namık Kemal, nazire, Tanzimat Reform Era, Encümen-

\section{Giriş}

1839'da Tanzimat Fermanı'nı ilan edildikten sonra bir yanı ile doğulu bir yanı ile batılı dünya görüşüne sahip şair ve yazarlar Batı edebiyatının özellikle de Fransız edebiyatının tesirinde eser vermeye başlar. Edebiyatımızın yenileşme yolunda kör-topal ilerlemeye çalıştı̆̆ bu süreç, eski ile yeninin, doğu ile batının harmanlandığı gri bir dönemdir. Şair ve yazarların nazım ve nesirde Batı edebiyatını örnek alınarak eser verdiği "Tanzimat Edebiyatı"; Hazırlık dönemi $\left(1839\right.$ - 1860) ${ }^{1}$, Birinci Nesil $(1860-1876)^{2}$ ve İkinci nesil $(1876-1896)^{3}$ olmak üzere üç dönemde incelenebilir.

\footnotetext{
${ }^{1}$ Ramazan Korkmaz (2005). "Yeni Türk Edebiyatına Giriş / Hazırlık Dönemi ve İlk Denemeler", Yeni Türk Edebiyatı El Kitabı (1839-2000), [Ramazan Korkmaz (ed.) - Hülya Argunşah - Ali İhsan Kolcu - Ayşenur Külahlıoğlu İslam - Cafer Gariper -Osman Gündüz - Tarık Özcan], 2.bs., Ankara: Grafiker Yayınları, ss. 13-40.

${ }^{2}$ Nihad Sami Banarlı (1983). "Şinâsî - Ziya Paşa - Namık Kemal Mektebi ve Türk Edebiyatı / Cemiyet İçin Sanat Hareketleri",

Resimli Türk Edebiyatı Tarihi, 2.bs., İstanbul: Milli Eğitim Basımevi, C. 2, ss. 858-859; İsmail Parlatır (1992). "XIX. Yüzyıl Yeni Türk Şiiri / Tanzimat'ın Birinci Kuşağı”, Türk Dili, Aylık Dil Dergisi IV (ÇağdaşTürk Şiiri), S. 481-482 / Ocak - Şubat - Mart, ss. 10-17; Mustafa Üstünova (1992). "Divan Edebiyatının Tanzimat Birinci Dönem Sanatçıları Üzerindeki Etkileri”, Uludağ Üniversitesi, Eğitim Fakültesi Dergisi, C. VII, S. 2, Bursa, ss. 141-150; Cafer Gariper (2005). "Yenileşmenin Başlangıcı ve Öncüleri / Şinasi - Namık Kemal - Ziya Paşa - Ahmet Midhat Efendi", Yeni Türk Edebiyatı El Kitabı (1839-2000), [Ramazan Korkmaz (ed.) - Hülya Argunşah - Ali İhsan Kolcu - Ayşenur Külahlığlu İslam - Cafer Gariper - Osman Gündüz - Tarık Özcan], 2.bs., Ankara: Grafiker Yayınları, ss. 41-80; Saadettin Yıldız (2006). “Tanzimat’ın Birinci Nesli”, Tanzimat Dönemi Edebiyatı, 2.bs., İstanbul: Nobel Yayın Dağıtım, s. 121.

${ }^{3}$ Nihad Sami Banarlı (1983). "Ekrem - Hamid - Sezai Mektebi ve Türk Edebiyatında Sanat İçin Sanat Temayülleri", Resimli Türk Edebiyatı Tarihi, 2.bs., İstanbul: Milli Eğitim Basımevi, C. 2, ss. 915-916; İsmail Parlatır (1992). "XIX. Yüzyıl Yeni Türk Şiiri / Tanzimat’ın_kinci Kuşağı”, Türk Dili, Aylık Dil Dergisi IV (Çă̆daş Türk Şiiri), S. 481-482 /
} 
'Yeni Türk Edebiyatı'nın temellerinin atıldığı Tanzimat dönemi aynı zamanda geleneksel edebiyatın da hız kesmeden devam ettiği yıllardır. Akademik çalışmalar bu döneme genellikle değişen ve yeni olan üzerine odaklanmış, özellikle Tanzimat döneminde eser veren şair ve yazarların geleneksel anlayışa uygun olarak verdiği eserleri yeni ile kıyaslama yoluna gitmiş, bu eserleri geleneğin içindeki yeri yönüyle yeterinde değerlendirmemiştir. Edebiyatımızın yenileşmesinde ve değişmesinde olduğu kadar Tanzimat edebiyatının fikir hayatının oluşmasında ve olgunlaşmasında emeği geçen Namık Kemal, Şinasi ve Ziya Paşa bu yönüyle de incelenmesi gereken usta kalemlerdir. Bu çalışmada Namık Kemal'in şiirleri geleneğin içinde değerlendirilecek, şiirinin kaynakları üzerinde durularak 'yeni şiir'in oluşmasında adından söz ettiren şairin gelenekle örtüşen ve ayrılan yönleri ele alınacaktır.

19. yüzy1l, Osmanlı Devleti’nin sosyal, siyasî ve edebî hayatında önemli değişmelerin meydana geldiği bir dönemdir. 1839'da Tanzimat Fermanı'nın ilan edilmesiyle başlayan Batılılaşma faaliyetleri özellikle siyaset, toplum ve edebiyat alanında etkisini gösterir. "Hayat karşısında alınan tavır değişikliği, kendisini yeni bir üslup ile ifade eder. Bu vakıayı Tanzimat devrinde de görürüz. Politik, ekonomik, sosyal sahada birçok yenilik getiren Tanzimat, kendine has yeni bir ifade tarzı da yaratır (Kaplan, 2006: 61). İslam âleminde yaşanan duraklama ile Batı'da Rönesans'la başlayan gelişmelerin hız kazanması Türk edebiyatında görülen gelişme ve yenileşmenin temelini oluşturur. Elbette Türk edebiyatının birdenbire yeniliğe uyum sağlaması kolay olmaz. İslam medeniyeti dairesi içerinden doğmuş ve gelişmiş divan edebiyatının tesirinden sıyrılarak Batı tarzında bir edebiyat oluşturmak ancak 19. yy.'ın ikinci yarısında yavaş yavaş meydana gelir. Altı asırlık eski edebiyatın özünü oluşturan divan şiiri geleneğini değiştirmek kolay olmaz. Hatta yenileşme faaliyetleri yanında belli bir nesle mensup şairlerin eski şiir geleneğinden kopmama çabaları da dikkat çeker (Tanpınar, 1982: 252-253) Köklü bir geleneğe sahip şiir geleneğinden kopmak, oluşan kültürü bir tarafa bırakarak yeni bir şeyler ortaya koymak kolay değildir. Bu nedenle "Şairler farklı bir şiirle karşılaştıklarında, bu tür edebiyatı mantıklarıyla tercih etmekle birlikte, alışkanlıklarından vazgeçememişler, eski tarzda şiir söylemeye devam etmişlerdir" (Enginün, 2007: 20). Türk şiiri bu dönemde yenileşme yönünde yavaş, fakat ciddi bazı adımlar atma yoluna girmesinde eski şiirin yenilenememesinin de rolünü göz ardı etmemek gerekir. Şairler, eski şiirdeki bu sıkıntının farkına vararak arayış içine girerler. Eski şiire yeni bir ruh kazandırmak, yeni bir dil zevki oluşturmak amacıyla bir araya gelen "Encümen-i Şuara" şairleri eski şiirin canlanması yönünde önemli bir çaba göstermişlerse de yeni tarz şiir anlayışı karşısında varlıklarını uzun süre devam ettiremezler.

Eski şiiri canlandırmaya yönelik çabalar içerisinde "Encümen-i Şuara" ayrı bir öneme sahiptir. Hersekli Ârif Hikmet Bey'in Lâleli Çukurçeşme'deki evinde dostlarını misafir etmesi ile başlayan edebî sohbetler, edebî zevk, dünya görüşü ve fikrî anlayışta birleşerek aynı meşrepte olan birkaç şairin hoşça vakit geçirmek için buluşmaları, kendi eserlerini diğer şairlere beğendirme amacı ile gerçekleştirildiği bilinmektedir. "1277 yılı evâhirinde (Mayıs-Haziran 1861) Hersekli Ârif Hikmet Bey'in Laleli'de, Çukurçeşme'deki evinde Encümen-i Şuara teşekkül eder ve her salı muntazaman devamla bir seneye yakın sürer. Leskofçalı Galip Bey, şiirde herkes tarafından kabul edilen kudretiyle encümenin reisi konumundadır. Meclisin takipçisi olan şairler de şunlardır: Mehmed Lebib Efendi (1199-1284), Mustafa İzzet Efendi (1216-1293), Osman Nureddin Şems Efendi (1229-1311), Musa Kâzım Paşa (1237-1307), İbrahim Hakkı Bey (1238-1313), Sâlih Nâilî Efendi (1239-1293), Sâlih Fâik Bey (1241-1317), Mustafa Gâlip Bey (1245-1284), İbrahim Hâlet Bey (1253-1295), Mehmed Celâl Bey (1254-1300), Hersekli Ârif Hikmet Bey (1255-1321), Mehmed

Ocak - Şubat - Mart, ss. 17-29; Ali İhsan Kolcu (2005). "Yenileşmenin İkinci Kuşağı / Ekrem-Hamid-Sezai Mektebi", Yeni Türk Edebiyatı El Kitabı (1839-2000), [Ramazan Korkmaz (ed.) - Hülya Argunşah - Ali İhsan Kolcu - Ayşenur Külahlıoğlu İslam - Cafer Gariper - Osman Gündüz - Tarık Özcan], 2.bs., Ankara: Grafiker Yayınları, ss. 81-108; Saadettin Yıldız (2006). “Tanzimat'ın İkinci Nesli”, Tanzimat Dönemi Edebiyatı, 2.bs., İstanbul: Nobel Yayın Dağıtım, s. $139-141$. 
Memdûh Fâik Bey (1255-1343), Mustafa Refik Bey (1259?-1282), (Deli) Hikmet Bey (?-1306). ${ }^{4}$ Kayahan Özgül bu isimlere Sâdullah Râmi Bey, Mustafa Eşref Paşa, Mehmed Hayreddin İrfan Paşa, Yusuf Kenan Bey, Mustafa İzzet Efendi gibi isimlerin de eklenebileceğini ve encümenin âzâlarının değil müdavimlerinin olduğunu, bunların da tüm toplantılara katılmadıklarını belirtir (2015: 27). Bu şairler içerisinde Leskofçalı Galib Bey, Hersekli Arif Hikmet Bey ve Namık Kemal'in ayrı bir hususiyeti vardır. Leskofçalı Galib Bey, poetik fikirleri ve edebî zevkiyle toplantılara yön veren bir şairdir. Hersekli Arif Hikmet Bey ise Leskofçalı Galip Bey’in poetik fikirlerin hayata geçiren, dil zevki kazandıran kişidir. 21 yaşında meclise dahil olan Namık Kemal de şiirlerin bu topluluk içinde okunma işini üstlenir (İnal, 1334: 208-209).

Encümen şairleri, eski şiiri tekrarlamak ve bu şiirdeki hataları tekrarlamak yerine bir taraftan 17. yy.'ın unutulmaya yüz tutan mistik âlemini yeniden hatırlatmak isterken yaşadıkları dönemden de ayrılmak istemezler. Leskofçalı Galip, Sebk-i Hindî ile yeni düşünce tarzını birleştirmeyi dener. Şairlerden bazıları hece vezni ile şiir yazmayı dener, bazıları ise geleneğin mazmunlara ve motiflerine dönemin gerekliliklerine göre yenilik getirmek ister. Şiirlere başlık koymak, Batı'dan manzum tercümeler yapmak, çağın sosyal meselelerine bilinçli bir yaklaşım sergilemek, edebî tenkidi esere uygulamak gibi yenilikleri de göz önünde bulundurur. Şairler, eskinin tematik yapısını özler; fakat bunu yeni bir şekilde ifade etmeyi denerler (Özgül, 2015: 34).

Genç yaşlarda encümene dahil olan Namık Kemal'in edebî zevk ve kabiliyetinin gelişmesinde encümen şairlerinin özellikle Leskofçalı Galib Bey'in önemli bir etkisi vardır. Hatta meşhur Hürriyet Kasidesi'ni bile onun bir kıt'asından çıkartır. Namık Kemal encümende kendi şiirlerini okumakla birlikte Kâzım Paşa, Hersekli Ârif Hikmet, Hâlet ve Fâik Memduh Beyler'le müşterek gazeller yazar. Yine encümen şairlerinden Osman Şems Efendi, Leskofçalı Galib Bey ve Hersekli Ârif Hikmet Bey'e de nazireler söyler (Göçgün, 2009: 6). Namık Kemal'in şiir zemininin en önemli kilometre taşlarının bu toplantılarda atıldığını söylemek mümkündür. Namık Kemal'in şair olarak kabul edilmesi bu toplantılarda söylediği eski tarz şiir sayesindedir. Bir süre sonra bu zemin üzerine kendine has üslubunu oluşturur ve döneminin en etkili ismi haline gelir. Bu noktada Namık Kemal'in eski şiir ile ilgili şiirlerin anlaşılmasında kullanacağımız bazı görüşlerine de yer vermek gerektiğini düşünüyoruz. Bu görüşler onun eski şiir anlayışı ile yazdığı şiirlerin anlaşılmasında fayda sağlayacaktır.

Namık Kemal'in gerek divan şiiri gerekse şiir hakkındaki görüşlerinin oluşmasında Leskofçalı Galib Bey'in etkisi bilinmektedir. Bununla birlikte Şinasi'nin de önemli bir etkisi vardır. Namık Kemal Şinasi'nin etkisini şu şekilde ifade eder:

"Hangi senede olduğu hatırımda değildir: fakat zannıma göre 78 sene-i hicriyesinde olacak; bir ramazan günü kitap aramak için Sultan Beyazıd Camii avlusundaki sergiye girdim. Elime talik yazı litograf basma ile bir kâğıt parçası tutuşturdular. Yirmi de para istediler. Parayı verdim, kâğıdı aldım. Üstünde İlahî unvanını gördüm. Derviş Yunus İlahîsi zannettim. Bununla beraber okumaya başladım. O İlahî ne idi biliyor musun ne idi? Beni, yazdığım yazının şimdiki derecesine îsâl etmeğe, milletin lisanının şimdiki haline getirmeğe sebeb-i müstakil olan İlahî bir İlahî idi. Sade fikre ne kadar da yakışır. Mebâdîsi şudur:

Hak Teâlâ azamet âleminin pâdişehi

Lâ-mekândır olamaz devletinin tahtgehi

\footnotetext{
4 Hersekli Ârif Hikmet, Divân, Âsâr-1 Müfîde Kütüphânesi-Matbaa-i Âmire, İstanbul, 1334, s.18-19.(Hersekli Ârif Hikmet Divanı'nı matbu olarak yayınlayan İbnülemin Mahmut Kemal'dir. Divan'ın başında, İbnülemin Mahmut Kemal tarafindan yazılmış olan Encümen-i Şuarâ, Hersekli Ârif Hikmet, şairliği ve divanı hakkında 78 sayfa tutan ve uzunuzun bilgi veren bir giriş vardır.)
} 
Nesren yazdığı şeyleri gördüğüm ve beğendiğim Şinasi'nin İlahî bir hâkim olduğunu o şiirinden anladım. Fakat fikrimi tamamiyle edebiyat arkadaşlarıma anlatamadım. Gittim, kendini buldum. Gazetesine muîn oldum. Merhum Şinasi, Tasvir-i Efkâr ile edebiyat-1 sahîhayı Osmanlı lisanında tesis etti. Bende gûyâ muini idim.”(Onan, 1951: 36-37).

Namık Kemal'in eski edebiyat ve Divan şiiri ile ilgili görüşleri konusunda özellikle "Lisân1 Osmanînin Edebiyatı Hakkında Bazı Mülâhazâtı Şâmildir" (Yetiş, 1989: 57) makalesi önemlidir. Kazım Yetiş bu makale ile ilgili olarak: "Bizde, çeşitli edebiyat meseleleri üzerinde düşünen ve düşündüklerini kaleme alan ilk müellif, Namık Kemal'dir. Ayrıca o, ilk münekkidimizdir. Bu bakımdan Namık Kemal, geleneği olmayan bir saha üzerinde kalem oynatmıștır. Lisân-ı Osmanînin Edebiyatı Hakkında Bazı Mülâhazâtı şâmildir makalesi, Türk edebiyat ve fikir hayatında dil ve edebiyat meselelerinin ele alındığı hemen ilk ve ihatalı makaledir. (...) Bu makale bir manada kültür ve edebiyat hayatımızda yapılmak istenen bir ihtilâlin beyânnâmesidir." demektedir. (Yetiş, 1989: 22-23).

Namık Kemal makalesinde sözün önemi üzerinde durur. Ona göre; "İşte kelâm müdavele-i tasavvur hizmetine kudretten müvekkel bir cism-i lâtiftir ki, binlerce seneler geçse taravet-i nevcivânîsine zevâl erişmez." Sözü latif bir cisim olarak tanımlayan şair, sözün düşünceleri anlatmak için bir vasıta olduğunu, düşünce taşımayan bir sözün hiçbir işe yaramayacağını söyler. (Parlatır vd., 2006: 223) Namık Kemal'in eski edebiyata yaptığı en önemli tenkitlerden biri doğaya ve gerçeğe uygunlukla ilgilidir. Şair, gerçeğe uygun bir edebiyat istemektedir. Diğer önemli bir tenkit de dil ile ilgilidir. Ona göre divan şairleri sunî bir dil meydana getirmiştir. Bu dili halk anlayamadığı için edebiyatla ilgilenmemiş böylelikle bir edebiyat dili oluşmamış "şive-i lisan" dan uzaklaşmıştır.

Eski şiirin lafzı manaya tercih ettiğini ifade eden şaire göre söylenmek istenen açık seçik şekilde ifade edilmemiş, külfetli sanatlarla yüklü bir dil ve özellikle Fars edebiyatının aşırı mübalağaları sıkça kullanılmıştır. Ayrıca Namık Kemal, edebiyatın bilgiyi ve kültürü yaymak ve millî birliği sağlamak gibi bir görevi olması gerektiğini de belirtir. (Parlatır vd., 2006: 223) Kaya Bilgegil, şairin bu makalesinde belirttiği tüm tenkitlerin çıkış noktasını şu ifade ile belirtir: "Şaire göre, cemiyetin diğer müesseselerinde görülen -1slahat- ihtiyac1, edebiyat için de varittir." (Bilgegil, 1972: 22).

Namık Kemal hakkında yapılan araştırmalarda ${ }^{5}$ onun Eski Türk Edebiyatı geleneği ve kültürü içerisinde yetiştiği, küçük yaşta şiire başladığı, Encümen-i Şuarâ’ya katıldığı, zamanındaki

\footnotetext{
${ }^{5}$ Hakkında geniş bilgi için bkz. Ebuzziya Tevfik (1908). Kemal Bey'in Terceme-i Hali, İstanbul: Ebuzziya Matbaası, İstanbul; Kemal-zade Ali Ekrem (Bolayır) (1908). Rûh-i Kemal, İstanbul: Mehmed Bey Matbaası; Süleyman Nazif (1922). Namık Kemal, İstanbul: İkdam Matbaası; Süleyman Nazif (1925). İki Dost (Namık Kemal - Ziya Paşa), İstanbul: Kanaat Kütüphanesi; Ali Ekrem Bolayır (1920). Namık Kemal,İstanbul: Maarif Basımevi; Kemaleddin Şükrü (1931). Namık Kemal, İstanbul: Kanaat Kütüphanesi; İsmail Hikmet (Ertaylan) (1932). Namık Kemal, İstanbul: Kanaat Kütüphanesi; Necip Fazıl Kısakürek (1940). Doğımunun Yüzüncü Yıl Dönümü Dolayısıyle Namık Kemal Şahsı - Eseri - Tesiri, Ankara: Türk Dil Kurumu Yayınları, , 6+[4]+316+LXXXVIII s.+7 adet resim; Komisyon (1942). Namık Kemal Hakkında, İstanbul: Dil ve Tarih-Coğrafya Fakültesi Türk Dili ve Edebiyatı Enstitüsü Neşriyatı: 2, Vakit Matbaası; Mehmet Kaplan (1948). Namık Kemal Hayatı ve Eserleri, İstanbul: İstanbul Üniversitesi Edebiyat Fakültesi Yayınları, 240 s.; Hikmet Dizdaroğlu (1954). Namık Kemal, Hayatı, Sanatı, Eserleri, İstanbul: Varlık Yayınları; Vasfi Mahir Kocatürk (1955). Namık Kemal'in Hayatı, İstanbul: Buluş Yayınevi; Yaşar Köksal (1957). Namık Kemal, İstanbul: Şevket Ünsal Matbaasi; Aslan Ergüç (1959). Namık Kemal, Konya: Şahap Kitabevi; Besim Akımsar (1961). Namık Kemal, Hayatı, Kişiliği, Mücadelesi, Eserleri, İzmir: Kovan Kitabevi; Muhammed Abdüllatîf Herîdî (1972). Nâmık Kemâl Hayâtuhu ve Âsâruhu [Namık s.; Kazım Yeti_(1993). "Edebiyat Nazariyesi Kitaplarında Namık Kemal'in Eserlerinin Örnek Olarak Değerlendirilişi”, Doğumunun Yüz ellinci Yllında Namık Kemal, Ankara: Atatürk Kültür, Dil ve Tarih Yüksek Kurumu Atatürk Kültür Merkezi Yayını - Sayı 67, ss. 117 - 136; Hayrettin Ayaz (1995). Tanzimat Şiirinde Metafizik Konular (Şinasi, Ziya Paşa, Namık Kemal, Recaizade M. Ekrem, Abdülhak Hâmid, Muallim Nâcî), Basılmamı_Doktora Tezi, Elazığ: Fırat Üniversitesi, Sosyal Bilimler Enstitüsü, Türk Dili ve Edebiyatı Anabilim Dalı, 276 s.; İskender Pala (1997). "Devlet Olmanın Beş Şartı", Şi'r-i Kadîm / Șiir Şerhleri, İstanbul: Ötüken, ss. 100-102; Nazir Akalın (1997). "Namık Kemal'in Eski Türk Edebiyatına Bakış1”, Dergâh, Edebiyat, Sanat, Kültür Dergisi, C. 8, S. 94, Aralık, ss. 14-17; Taha Toros (1998). Türk Edebiyatından
} 
eski şiir temsilcilerinden etkilendiği, eski şiirin önemli şairlerine olduğu gibi devrinin ünlü veya az tanınmış şairlerine nazireler yazdığı bilgileri genel bir kabuldür. Bununla birlikte Şinasi ile tanışmasından sonra şiirinin özellikle muhtevasının değiştiği ancak şekilde eskiye bağlı kaldığı, az da olsa şekille ilgili bazı arayışları olduğu da bilinmektedir.

Bu çalışmada Namık Kemal, bir divan şairi olarak ele alınarak şairin divan şiirleri özellikle nazireleri üzerinde durulacaktır. Namık Kemal, şiire nazîrelerle başlar ve şiirlerini nazîrecilik üzerinde devam ettirir. Kronolojik olarak şiirler sıralanamasa da şairin hemen hemen bütün şiirlerinde nazîreciliğin etkisi görülür. Bu etkiyi Necip Fazıl yanlış değerlendirerek şairi şöyle eleștirir: "Namık Kemal'in divanını başından sonuna kadar ve en iyi niyetle okuduğumuz zaman görürüz ki, onda hiçbir mizaç ve meşrep farikası, duygu v e düşünce şahsiyeti, inşa ve mimarî

Altı Renkli Portre: Namık Kemal, Mehmet Akif, Abdülhak Hamid, İbnülemin, Yahya Kemal, Abdülhak Şinasi, İstanbul: İsis Yayıncılık; İsa Kocakaplan (1999). Namık Kemal, İstanbul: Timaş Yayınları, 150 s.; Önder Göçgün (1999). Namık Kemal'in Şairliği ve Bütün Şiirleri, 1.bs., Ankara: Atatürk Kültür Merkezi Başkanlığı Yayınları, XCIV+468 s.; Abdullah Şengül (2000). "Yeni İnsan Anlayışı Çerçevesinde Namık Kemal'in Hürriyet Kasidesi'ne Genel Bir Bakış", Afyon Kocatepe Üniversitesi Sosyal Bilimler Enstitüsü Sosyal Bilimler, C. II, S. 1, Nisan, ss. 25-34; Harun Kurt (2001). Namık Kemal'de Din ve Sosyal Felsefe, Basılmamı_Yüksek Lisans Tezi, Ankara: Ankara Üniversitesi, Sosyal Bilimler Enstitüsü, Temel İslam Bilimleri Anabilim Dalı, V+128 s.; Osman Gündüz (2002). "Namık Kemal'in Şiirlerinde Fonetik Unsurlar ve Kişi Zamirlerinin Kullanılışı”, Bilig / Türk Dünyası Sosyal Bilimler Dergisi, No: 20, ss. 125-139; Halil Ersoylu (2003). "Hürriyet Kasidesi'nin Metin Örgüsü ve Bunun Namık Kemal'in Yeni Şiirindeki İzleri”, Türk Dili Araştırmaları Yıllı̆̆ $l$ Belleten, C. 1, Ankara, ss. 23-38; Fevziye Abdullah Tansel (2005). Hususi Mektuplarına Göre Namık Kemal ve Abdülhak Hamid, Ankara: Akça_Yayınları; Abdullah Uçman (2006). "Namık Kemal", Tanzimat Edebiyatı, (Haz.: Abdullah Uçman - Ahmet Bican Ercilasun - İnci Enginün - İsmail Parlatır - Nurullah Çetin - Zeynep Kerman), 1.bs., Ankara: Akça_ Yayınları, ss. 201-288; Abdullah Uçman (2007). "Namık Kemal'in Divan Edebiyatına İtirazları", Kitap-lık, Aylık Edebiyat Dergisi [Dosya: Eski Edebiyata Yeni Yorumlar], S. 107, Temmuz - Ağustos, ss. 73-77; Önder Göçgün (2009). Edebiyat ve Kültür Dünyamızda Namık Kemal, Hayatı, Eserleri, Edebî Kişilĭği ve Eserlerinden Açıklamalı Seçmeler, 1.bs., Ankara: Atatürk Kültür Merkezi Yayınları, 222 s.; Ali ihsan Kolcu (2010). Namık Kemal'in Poetikası, 1.bs., Erzurum: Salkımsögüt Yayınevi, 96 s.; Canan Öktemgil Turgut (2010). "Namık Kemal'in Vaveylâ Adlı Şiirinde Vatan Anlayışı", Prof.Dr.Bilge Ercilasun Armağanı, Ankara: Pegem Akademi Yayınları, ss. 315-322; Orhan K. Tavukçu - Turan Karata_ (haz.) (2011). Namık Kemal, 1.bs., Ankara: Kültür ve Turizm Bakanlığı Yayınları, 528 s.; Süleyman Nazif (2011). Namık Kemal [Haz. Mehmet Samsakçı], İstanbul: Kitabevi Yayınları, XXI+177 s.; Abdulhalim Aydın (2011). "Namık Kemal'i Victor Hugo'ya Götüren Etkenler", Turkish Studies - International Periodical For the Languages, Literature and History of Turkish or Turkic, Vol. 6/3, Summer, pp. 197- 204; Hüseyin Su - Abdurrahim Karadeniz (ed.) (2012). Namık Kemal, Tekirdağ: Namık Kemal Üniversitesi Yayını, 448 s. Namık Kemal, Hayatı ve Eserleri], Kahire: Câmi'atü Ayn şems, Külliyyetü'l-Âdâb (Basılmamı_Master Tezi), 190 s. (Edebiyat Fak. Kütüb. No: 17673-17674, Yeni No: 459-460); M.Kaya Bilgegil (1972). Harabat Karşısında Namık Kemal: Namık Kemal'in Eski Edebiyata İtirazlarl, 1.bs., İstanbul: İrfan Yayınevi, 303 s.; Mehmet Kaplan (1981). "Hürriyet Kasidesi”, Tanzimat'tan Cumhuriyet'e Şiir Tahlilleri, 7.bs., İstanbul: Dergâh Yayınları, C. 1, ss. 37-45; Ahmet Hamdi Tanpınar (1982). "Namık Kemal", 19 'uncu Asır Türk Edebiyatı Tarihi, 5.bs., İstanbul: Çağlayan Kitabevi, ss. 342-444; Kenan Akyüz (1982). "Tanzimat Devri-_iir”, Modern Türk Edebiyatının Ana Çizgileri (1860-1923) I, 4.bs, Ankara: Mas Matbaacilık ve Aksesuvarları, ss. 23-25; Nihad Sami Banarlı (1983). "Namık Kemal (1840-1888)", Resimli Türk Edebiyatı Tarihi, 2.bs., İstanbul: Milli Eğitim Basımevi, C. 2, ss. 879- 914; Osman Nuri Ekiz (1984). Namık Kemal, Hayatı, Sanatı, Eserleri, İstanbul: Gökşin Yayınları; Kenan Akyüz (1986). "Namık Kemal”, Batı Tesirinde Türk Şiiri Antolojisi, 4.bs., İstanbul: İnkılâp Kitabevi, ss. 52-61; Önder Göçgün (1987). Namık Kemal, Ankara: Kültür ve Turizm Bakanlığı Yayınları; Bedri Aydoğan (1987). Namık Kemal'in Eserlerinde Sanat ve Edebiyat Görüşleri, Basılmamış Yüksek Lisans Tezi, Ankara: Ankara Üniversitesi, Sosyal Bilimler Enstitüsü; Dursun Gürlek (1988). Namık Kemal, Hayatı - Sanatı - Eserleri, İstanbul: Boğaziçi Yayınevi; İsmail Parlatır (1988). "Namık Kemal'in Lâzımsa Redifli Gazelleri ve Nazireleri”, Ölümünün 100. Yılında Namık Kemal, İstanbul: Marmara Üniversitesi Yayınları, ss. 161-183; Emine Kara (1988). Namık Kemal'in Eserlerinde Benzetme Unsurları, Basılmamı_Bilimde Uzmanlık Tezi, İstanbul: İstanbul Üniversitesi, Sosyal Bilimler Enstitüsü, 737 s.; Kâzım Yeti_(1989). Namı-k Kemal'in Türk Dili ve Edebiyatı Üzerine Görüşleri ve Yazıları, İstanbul: İstanbul Üniversitesi Edebiyat Fakültesi Yayınları; İsmail Parlatır (1989). "Namık Kemal'in Edebiyatımıza Getirdiği Yeni Değerler", Gazi Eğitim Fakültesi Dergisi, C. V, S. 1, Ankara, ss. 37-46; Bilge Ercilasun (1989). "Namık Kemal'in Şiirleri Hakkında", Gazi Ĕ̆itim Fakültesi Dergisi, S. 1, Ankara; Önder Göçgün (1991). "Namık Kemal'in Yazdığı İlk Beyit”, Türk Edebiyatı Araştırmaları II, Konya: Selçuk Üniversitesi Yayınları, ss. 202-204: “...Namık Kemal, henüz 12 yaşında iken Kars’ta ilk beytini yazdı...”; Etem Çalık (1991). "Namık Kemal'in Edebiyat Hakkındaki Görüşleri”, İslâmî Edebiyat, S. 14, Ekim-Kasım-Aralık, ss. 21-22; Komisyon (1993). DoğumununYüz ellinci Yılında Namık Kemal, Ankara: Atatürk Kültür, Dil ve Tarih Yüksek Kurumu Atatürk Kültür Merkezi Yayını - Sayı 67, $\mathrm{XV}+280$. 
hususiyeti; hasılı onun öz şiir mayasını gösterecek, mücerret plânda hiçbir ruh ve kafa ukdesi yoktur. Namık Kemal'in divanı, bir baştan öbür başa, bir takım büyük ve küçük şairlerin demirbaş tefekkür unsurlarıyle, orta malı tahassüs posalarının, çok defa aynı şekiller içinde ve hep kaba akıl zemininde tekrar tekrar düzene sokuluşundan ibarettir." (Kısakürek, 2009: 137) Necip Fazıl'ın bu eleştirisine katılmak mümkün değildir. Nazîre yazmanın usta-çırak ilişkisi ve orijinal olamama çerçevesinde değerlendirilmesi nazîrecilik geleneğini görmezden gelmek olarak görülmelidir. Nazîre "Bir şair, başka şairlerin hürmetini kazanmış ise; şair veya şiiri kalıcı bir şöhreti yakalamış ise; bir şairin üslûp ve edâsı beğeniliyorsa; bir şairin gazele getirdiği yenilik varsa, o yeniliği paylaşmak için; bir şairin ününe ve sanatının derecesine ulaşmaya gayret ediliyorsa; bir şair, genç ediplerin kişilik bulma ve ustalaşma gayretlerindeki merhalesinin emsâl kişisi ise; destek olunacak yeni şairler varsa; bir şair, üstad ediblere sanatının ve şiirinin üstünlüğünü ispatlamaya çalışıyorsa; bir gazele, başka şairlerden daha güzel nazîre söylemek müsabaka ve imtihan mânâsı kazanmış ise; şiirin anatomik ve tematik yapısında beliren bozulmaların ilacı olarak, kudretli şairleri taklit düşünülüyorsa; bir cemâat veya cemiyet olduğunu fark etme gayreti yaşanıyorsa; güçlü bir fikre açllan muhalif cepheyi güçlendirmek için şiirin birleştiriciliğinden medet umuyorsa" (Özgül, 2014: 38-50) gibi nedenlerle yazılabilir. Bu bir eksiklik değil, geleneğin sürdürülmesi noktasında zincir halkalarının birbirine eklenmesidir. Namık Kemal'in şiirlerinde nazîre etkisinin bu kadar fazla olmasını bu amaçlar çerçevesinde değerlendirmek gerekir.

Namık Kemal'in şiirleri incelendiğinde şairin şiirlerinin çoğunun gerek çağdaşı olan şairlere gerek eski divan şairlerinin şiirlerine nazirelerden oluştuğu görülmektedir. Şairin nazirelere başvurmasında özellikle "Encümen-i Şuara" toplantılarının etkisi olduğunu düşünebiliriz. Bu toplantılarda diğer şairlerin şiirleri okuma görevini üstlenen Namık Kemal, bu şairlere nazireler yazarak hem kendi şairliğini pekiştirmiş hem de divan şiiri geleneğinin devamında önemli bir rol üstlenmiştir. Şair, daha sonra divan şiirini eleştirmiş olsa bile divan şiir geleneğine bağlı yazdığı şiirler, onun güçlü bir divan şairi olduğunu da göstermektedir. Biz bu çalışmada Namık Kemal'in yazdığı nazireleri, nazire yazılan şiirlerle karşılaştırarak mazmun, kavram, motif, hayal, fikir, duygu gibi unsurların şiirlerde ne gibi değişim ve dönüşümlere uğradığını ve Namık Kemal'in divan şairi olarak önemini ortaya koymaya çalışacağız.

Namık Kemal'in şiirleri incelendiğinde ${ }^{6}$ şairin 16. yy. şairlerinden Fuzuli'nin 11, Baki'nin 1, Şeyhülislam Yahya'nın 1; 17. yy. şairlerinden Naili'nin 13, Fehim-i Kadim'in 5, Nabi'nin 3 Nef'i'nin 4, Vecdi'nin 4, Şeyhülislam Bahayi'nin 2, Danişi Ali Dede'nin 1, Diyarbakırlı Hâmi'nin 1 gazelini; 18.yy. şairlerinden Nedim'in 1 gazelini; 19.yy. şairlerinden Leskofçalı Galip Bey'in 52, Hersekli Arif Hikmet Bey'in 32, Fehim'in 17, Osman Şems'in 15, Halet Bey'in 5, Arpaeminizade Sâmi'nin 7, Şem'i'nin 1, Selim'in 1, Faik-i Memduh'un 2, Şinasi'nin 1, Akif Paşa'nın 1 gazelini olmak üzere toplamda 182 şiiri tanzir ettiği görülmektedir. Namık Kemal'in tüm şiirleri göz önüne alındığında bu azımsanmayacak bir rakamdır. Encümen şairlerinin hemen hepsinde görüldügüü üzere Namık Kemal de önceki yüzyılın hatalarını tekrarlamak yerine, 17. Yüzyılın artık unutulmaya yüz tutan mistik âlemine yeniden girmeyi ancak yaşadıkları devirden de tecrid olmamayı dener. Bu genel açıklamalardan sonra şairin nazirelerini incelemeye geçebiliriz.

Nazireler incelenirken kronoloji takip edilerek eskiden yeniye değişen, değişmeyen öğeler ortaya konulmaya çalışılacaktır. Şairin çağdaşı olduğu şairlere yazdığı nazirelerde ise gerek söyleyiş̧ farklılıkları gerekse dönemin şiir anlayışı ile olan paralellikler üzerinde durulacaktır.

\section{1) 16.yy. Şairlerine Yazılan Nazireler}

\footnotetext{
${ }^{6}$ Şiirlerin seçiminde ve incelenmesinde şu eserlerden yararlanılmıştır: Saadet Nüzhet Ergun, Namık Kemal'in Hayatı ve Şiirleri, Historia Yayınları, İstanbul 2018; Ali Ertem, Namık Kemal'in Şiirleri, Yeni Matbaa, İstanbul 1957; Kenan Akyüz, Batı Tesirinde Türk Şiiri Antolojisi, İnkılap Kitabevi, İstanbul 2017; Mehmet Kaplan, İnci Enginün, Birol Emil, Yeni Türk Edebiyatı Antolojisi II, 1865 - 1876, İstanbul Üniv. Edebiyat Fak. Yayınevi, İstanbul 1978
} 
Namık Kemal, 16. yy. şairlerinden Fuzuli, Baki, Şeyhülislam Yahya'nın şiirlerine nazire yazmıştır. Bu şairler içerisinde Fuzuli, 11 şiirine nazire yazılarak ilk sırayı almaktadır. Namık Kemal'in bu şairlere yazdığ 1 nazirelere geçmeden önce şairin neden özellikle bu şairlere nazire yazdığı üzerinde de kısaca durmak istiyoruz.

Gerek 16.yy. divan şairleri arasında gerekse daha sonraki yüzyıllarda bilinen divan şairleri arasında önemli bir yere sahip olan Fuzuli’nin, şiir ve edebiyata bir şair ve mütefekkir özelliği ile yaklaştığı bilinmektedir. Fuzuli'nin şiir hakkındaki görüşleri incelendiğine iki özellik Namık Kemal'in şairin şiirlerine neden nazire yazdığı hakkında dikkat çekicidir. "Şiir, Fuzuli'ye göre insanlığı yücelten amaçlar doğrultusu veya insanî değerleri koruma gayesi dışında, sadece nefsanî duyguların, egoistçe arzuların tatmini yolunda kullanılırsa çok tehlikelidir ve bu yolda şiir yazan şairler sonunda hüsrana uğrayacaklardır. Olumsuz gayeler dahilinde değil de, iman ve salih amel doğrultusunda şiir yazanlar bu kötü akıbete yuvarlanmaktan kurtulmuşlar ve hatta amaçlarına nail olmuşlardır." (Doğan, 1996: 48-49) Fuzuli'nin bu görüşü Namık Kemal'in Emir Nevruz Tercümesi'ndeki “edebî eser mürebbi-i ruh müzekki-i efkar olan emsal-i hayatın tezyininde" (Yetiş 1989: 60-61) ifadeleri ile örtüşmektedir. Edebî eserin özel de ise şiirin "mürebbi-i ruh" olması ve "müzekki-i ruh" görevini yerine getirmesi gerektiği Fuzuli’nin şiirdeki ahlak düşüncesi ile paralellik gösterir. Yine Fuzuli’ye göre "Allah mevzun kelama (ölçülü ve düzgün söze) önem vermiş ve insan oğlunu güzel ve ölçülü sözden hoşlanan bir tabiatta yaratmıştır. Yine Allah, Kur'an'ın başına tac gibi, Besmele'yi koyarak irfan ve idrak sahiplerinin kalplerine mevzun (vezinli, düzgün) kelam sevgisini yerleştirmiştir." (Doğan, 1996: 51) Namık Kemal, her ne kadar Celal Mukaddimesi'nde "Mâlum olduğu üzere, bizde usûl-i nazm, lisânın tabîatine tamamiyle mugayir olarak letâfet-i ifâdeyi bütün bütün ihlâl etmedikçe zebânzed olan tâbirlerimizin yüzde birini şiirde kullanamayı! Kullandığımız tabirleri de ya vezne veya telâffuz-1 aslîye tatbik için hurûf ve harekâtında ihtiyat ettiğimiz imâlât ile bütün bütün şive-i lisandan çıkarmaya muhtaç oluruz" (Kemal, 1989: 341 - 379) diyerek aruz veznini eleştirmiş olsa da kendisi heceye itibar etmez. ${ }^{7}$ Burada şu hususu da belirtmek gerekir: Namık Kemal aruz vezninin hece vezninden önce de bizim veznimiz olduğu bilgisini görmezden gelir. Eski şiiri yıkmanın da aruz vezninden başlaması gerektiğine inanır. Aruz vezni ya da hece ölçüsü konusunda farklı düşüncelere sahip olsa da Namık Kemal, şiirin ölçülü ve düzgün olması gerektiğini kabul eder. Şiirlerinde de vezin hatalarına sık rastlanmaması bu özelliğini gösterir. Ölçülü yazma konusunda da Namık Kemal ile Fuzuli'nin görüşleri arasında bir uyum söz konusudur.

Namık Kemal, 16. yy. şairleri içerisinde en fazla Fuzuli'nin gazellerine nazire yazar. Fuzuli'nin fikir ağırlıklı, aşk ve ızdırab yüklü şiirleri Namık Kemal'in oldukça ilgisini çeker. Fuzuli'nin;

Pembe-i merhem-i dağ içre nihandur bedenüm

Diri oldukça libâsun budur ölsem kefenüm

dizeleriyle başlayan gazelini tanzir eder. Şem'i'nin de tanzir ettiği bu gazelde Fuzuli, Tasavvufî bir aşk olgusundan bahseder. Divan edebiyatında sıklıkla karşılaşılan "dâğ, dil, tiğ, leb, dehen, kadd, gonca, servi, semen" mazmunlarının da kullanıldığı gazelde sevgiliye, fenâfillaha ulaşmanın arzusu anlatılır. Namık Kemal'in gazelinde ise divan edebiyatının bu klasik mazmunlarının azaltılarak daha somut bir anlatım benimsediği dikkat çekmektedir. Fuzuli’nin

Işk ser-gerdânıyım seyl-i sirişk içre yerüm

Bir habâbem ki hevâdan doludur pîrehenüm

\footnotetext{
${ }^{7}$ Namık Kemal'in sadece Celâleddin Harzemşah’ta cellat türküsü, Gülnihâl'de mezarcı türküsü, Âkif Bey'de düğün ve meyhâneci türküsü gibi birkaç şiir haricinde hece veznini kullanmamıştır.
} 
(Aşk ile âvâre dönüp duruyorum. Yerim de gözyaşı seli içindedir. Bir su kabarcı̆̆ıyım ki gömleğim hava ile doludur.) (Tarlan: 458)

dizelerindeki hayal, Namık Kemal'in gazelinde;

Dâmen-i Yûsuf olursa yine sad çâk olsun

Belki tig-1 gamına hâil olur pîrehenim (s. 333)

dizelerinde daha somut bir hal alır. Fuzuli, vahdet aleminden "vatanım" kelimesi ile işaret ederken Namık Kemal işaretle yetinmez, "mest-i sahbâ-yi Elest" olarak asıl maksadı işaret etmeden, gösterir. Namık Kemal, Fuzuli'nin şiirlerine yüklediği anlamı bazen somutlayarak bazen de bazı mazmunları açarak ayrıntılı bir şekilde tasvir eder. Fuzuli’nin "eylerim" redifli gazeline yazdığg nazire de aşk acısını ve bu acının verdiği olgunluk üzerinde durur. Fuzuli'nin;

Levh-i âlemden yudum eşk ile Mecnûn adını

Ey Fuzûli men dahi âlemde bir ad eylerem (Tarlan: 480)

(Âlem sahifesinden gözyaşımla Mecnûn'un adını sildim. Ey Fuzuli ben de bu suretle âlemde Mecnûn gibi bir şöhret sahibi oldum.)

dizelerinde kendisini aşkın sembolü hale getirişini, Namık Kemal daha ileriye götürür:

I'tibârım şöyledir kim ayş u nûş âyînine

Rindlik mahvolsa âlemde ben îcâd eylerim (s.334)

Dünyada “visâl”in imkansızlığını söyleyen Fuzuli’nin ümitsizliğine karşı, Namık Kemal daha yapıcı bir tavır takınır. Dünyayı acı çekme mekânı olarak gören Fuzuli'nin karşısında "haşre dek" ümidini kaybetmeyen (Tarlan: 479) bir anlayışa sahiptir. Sevgilinin zulmüne dayanabilmek için bütün varlığın zulmünü kabul eden Fuzuli, bu zulm ile sevgiliye ulaşma gayretindedir. Namık Kemal ise çektiği acı ve gördüğü zulmü başkaları için bir kurtuluş reçetesi olarak sunar:

Kubbe-i eyvân-1 çarhı âh ile yıksam nola

Bin yıkılmış kalbi enkaz ile âbâd ederim (s.334)

Namık Kemal, Fuzuli'nin şiirlerine yazdığı nazirelerde bazen anlam genişlemesi bazen de anlam daralması yaparak şairle bir duygu ortaklığı oluşturmaya çalışır. Fuzuli'nin "Şâh-1 mülk-i mihnetem dutmuş cihânı leşkerim" (Ben mihnet mülkünün şâhıyım, askerim bütün cihânı tutmuş) (Tarlan 463) dizesinde bütün cihan olarak belirtilen mekân Namık Kemal'de "Kerbelâ'yım ben şehîd olmuş serâser leşkerim" (sy. 334) dizelerinde "Kerbelâ" ile sınırlanır. Aşk acısının görünümü, her iki şairde de benzer mazmunlarla, aynı anlam çerçevesi içerisinde verilir:

Seyl-âb-1 sirişk ile hoşem 1şk yolunda

Hâşâk-1 ta'alluk koparur reh-güzerümden

(Gözyaşı seli ile başım hoştur. Çünkü aşk yolunda masivaya bağlanma çerçöpünü yolumun üzerinden koparır, sürükler götürür) (Tarlan 550)

Âhım yeli esdikçe hoşum aşk yolunda

Kim sedd-i taalluk dağıdır rehgüzerimden (sy. 343)

(Ah yelim estikçe hoşum. Çünkü aşk yolunda yolumun üzerinden masivaya bağlanma seddinin dağıdır, masivaya bağlanmaya engel olur.) 
Divan edebiyatında sevgili daima insafsız ve zalimdir. Çünkü âşıklara yüz vermez. Onları daima naz ve gaflet ile perişan eder. Hakiki sevgili Allah olduğuna göre ona insafsızlık, zulüm atfetmek büyük günahtır. Ancak zâhiren zulüm gibi görünen şey hakikatte en büyük nimettir. Çünkü âşık bu zulüm ile olgunlaşır. "Görüp" redifli gazelde Fuzuli bu paradoks üzerinde durur. Aşk acısı şairi o kadar olgunlaştırır ki onun derdini tedaviye uğraşan tabip bile onu tedavi etmekten vazgeçer:

Eyleyen ta'yin-i eczâ-yi müdâvâ derdime

Terk edüb cem etmedi hâl-i perîşânum görüb (Tarlan 109)

Namık Kemal de perişan saçlarını gören bulutların sersemlediğini, yıldırımların feryâd ettiğini söyler. Fuzuli'nin "çeşm-i gevher-efşân" (dönen bileği taşına vurulan bıçağın kıvılcım saçması) mazmunu Namık Kemal'de "berklerin feryadına" döner:

Ebrler sergeştedir zülf-i perişanın görüp

Berkler feryâd eder rûy-i dirahşânın görüp (sy. 367)

Fuzuli'nin Leyla ve Mecnun mesnevisinde Leyla ile Mecnun'un karşılaşmalarında, Mecnun'un kendinden geçip tanıyamadığı Leylâ'ya hitabı olarak yazdığı "nedir" redifli gazel, varlık âleminin bir sorgulamasıdır. Şair, bu gazelinde mecazi aşk anlayışından sıyrılarak İlahî aşka doğru yükselişin verdiği heyecanı dile getirir. Sevgiliye kavuşmak âşı̆̆ın tek isteğidir. Asıl gaye vuslattır. Bu gaye, dünyevî arzuların hepsinden önde gelir ve bir âşı̆̆ı doyuracak yegâne arzudur. Mahlas beyitte şair, içinde bulunduğu durumu sorgular:

Ah u feryâdın Fuzûlî incidibdir âlemi

Ger belâ-yı 1şk ile hoşnûd isen gavga nedir

(Ey Fuzûlî! Çektiğin ahlar ve feryatların bütün âlemi, bütün insanları ve varlıkları rahatsız etmiştir. Eğer aşk derdinden hoşnutsan, o halde bu mücadele ve kavga nedir?)

Namık Kemal'in naziresinde de varlık âlemi sorgulaması yapılır. İlmi, Fuzuli'de olduğu gibi ikinci sıraya koyan şair, dünyanın değersizliğini dile getirir. Dünyanın geçiciliği ve değersizliği divan şiirinde sıklıkla vurgulanan bir düşüncedir. İki şairin şiirleri kıyaslandığında ise Fuzuli doğrudan aşkı yüceltirken, Namık Kemal varlık âleminin değersizliğinden dem vurur:

Gamze müstağni cünun mühlik gönül müştâk-1 merk

Bir avuç hâke bu rütbe derd-i canfersâ nedir

Nâmık eyle himmetin âli ise ağyârı yâr

Bir denî dünyâ içün dünyâ ile gavga nedir (sy. 381)

Fuzuli'nin "içindir" redifli gazeli ile Namık Kemal'in aynı redifli gazeli ise büyük oranda benzerlik gösterir. Neredeyse tamamı teşbihlere dayanan gazelde her iki şair de sevgilinin aşkından çektikleri ızdırabı dile getirir. Fuzuli, sevgilinin bir yan bakışı için canını vermeye hazırdır. Çünkü can sevgilinin gamzesine vermek için vardır. Namık Kemal de var oluş gayesini ervah-1 ezelden ayrılışının sebebi olarak da sevgilinin kirpiklerinin görme ümidi olarak açıklar. Sevgili, sadece 1zdırap vermez. Aynı zamanda varlık aleminde ne var ne yok onun sayesinde bir deveran içerisindedir. Müjdelenen fetih de onun sayesinde olacaktır.

Fuzuli:

Bes ki hicrânundadur hâsiyyet-i kat'-1 hayât

Ol hayât ehline hayrânem ki hicrânumdadur (Tarlan 246) 
(Hayatı kesmek yani ona son vermek senin ayrılığının bir hassasıdır. Senden ayrı yaşayabilen insanlara hayranım.)

Namık Kemal:

Kişver-i imkân serâser zîr-i fermanındadır

Sûre-i Innâfetahnâ gamzenin şânındadır (sy. 389)

(İmkân iklimi baştanbaşa fermanındadır, Innâfetahnâ suresi - vaad edilen zafer - senin gamzenin şanındadır.)

"Eylemiş" redifli gazelinde sonbahar tasviri yapan Fuzuli, felekten şikâyet eder:

Tâ ki tâk-i zer-nigârın çarh vîrân eylemiş

Hışt-1 zerrînin sabâ ferş-i gülistân eylemiş (Tarlan: 335) yaymış.)

(Çarh, altın kakmalı tâkını vîrân eyleyince onun altın tuğlalarını rüzgâr, gül bahçesine

Çarh, altın kakmalı tâk1 - güneşli gök - yıkınca tuğlaları sarı yapraklar halinde gül bahçesine serpilmiş. Doğal bir döngü gereği sonbahara evrilen mevsim, şair için zamanın gökyüzünü yıkarak gül bahçesine yayması olarak görülür. Namık Kemal ise hasretin, ayrılığın gönlünde oluşturduğu yaraları gül bahçesine çevirdiğini söyler. Şiiri bülbül sesi gibi olsa da yaralar gönlünü kaplamıştır. Fuzuli’nin dış âlemde gördüğü ayrılı̆̆ın emarelerini, Namık kendisinde tasvir eder:

Nâmık olsa nola nazmım hem nevâ-yi andelîb

Dâğlardan sinemi hasret gülistân eylemiş (sy. 404)

Fuzuli'nin şiirlerinde acı, gam ve keder şairin bir türlü kurtulamadığı, kurtulmak istemediği duygulardır. Sevgili herkese lütfederken şaire cevreder. Bu âşı psikolojisidir. Tabi aşk, dert ister. Sevgili bütün nimet ve lütuflarıyla âlemi şâd eder. Âşığın ise dünya nimetleriyle işi yoktur. O âlemin gamını çeker:

Âlem oldu şâd senden men esîr-i gam henüz

Âlem etdi terk-i gam mende gam-1 âlem henüz (sy. 285)

Namık Kemal'in aynı redifli gazelinde de âşığın çektiği dert onu ihtiyarlatmıştır. Ancak aşk yarasının lalesi sevinç içinde durmaktadır. Zaman geçse de aşığın terk edemediği, terk etmek istemediği tek şey aşk yarasının izlerinin kaybolmamasıdır. Ömür geçse de aşk yarası bütün canlılığı ile durmaktadır. Fuzuli'nin bütün âlemin gamı terk etmesine rağmen kendisinde bütün âlemin gamının olduğunu söylemesi ile Namık Kemal'in zamanın geçmesine rağmen aşkın gam ve kederinin durması duygu paydaşlığı olarak görülebilir.

Âşık kendinden eser kalamayacak derecede yok olmalıdır. Gerçek bir âşı, aşk ile mahvolur. Ferhat'ı örnek veren Fuzuli, onun dağları delmesinin aşkının bir eseri olarak görür. Ferhat, taşa Şirin'in resmini çizer ve ona bakarak yorulmadan, bıkmadan usanmadan dağları deler. Ancak şair, aşkta mahvolmuş hiçbir eser bırakmamıştır. Bu nedenle de kendisini Ferhat'tan üstün görür:

Kûhkenden görünür kûhda âshar henüz

Ol ne benzer mana anun eseri vâr henüz (Tarlan: 309)

Namık Kemal, Fuzuli gibi bir karşılaştırmaya girmez. Sevgilinin bir bakışı biçarelere çare olurken şair aşk gamı ile hastadır. Ferhat'ın dağları delmesini aşkın bir izi olarak gören Fuzuli'nin 
beyti ile Namık Kemal'in beyti arasında aşkın iz bırakması arasında bir bağlam söz konusudur. Fuzuli, aşkın gamı ile mahvolurken, Namık Kemal aşkın kendisinde bıraktığı izlerle acıyı, gamı yaşamaya devam eder. Henüz aşkta gerçek olgunluğa ulaşamamıştır.

Namık Kemal, 16. yy. şairleri arasında Baki ve Şeyhülislam Yahya'nın da birer gazeline nazire yazar. Bâki, Kanuni döneminde estetik bakımdan zirveye erişen Osmanlı kültür ve sanat hayatının şiirdeki karşılığıdır. Özellikle benimsediği ölçü fikri, zamanının şairler zümresinden otorite sahibi kişiler tarafından da takdirle karşılanmıştır (Macit ve Kaplan, 2014). Şeyhülislam Yahya da Bâki'nin izinden giden kelime ve söz sanatlarına rağbet etmemiş, özellikle İstanbul Türkçesi ile yazmaya çalışmıştır. Şiirleri bilinenin aksine Tasavvufî tarzda değil, tam aksine beşeri zevk, hayaller ve rindane bir tarz hâkimdir. (Kuzucular, 2013) Namık Kemal de Bâki'nin ölçü konusundaki maharetinden, Şeyhülislam Yahya'nın ise sade ve yalın söylenişinden etkilenir. Baki'nin;

Gülsitan-1 bezm-i şerâb u câm-1 mey güldür bana

Kulkul-i hulk-i sürâhi savt-1 bülbüldür bana

(Gül bahçesi benim için şarap meclisi gibidir. Güller de şarap kadehi gibidir. Sürahinin halkaya benzeyen ağzından "kul kul" diye dökülen şarapnâmesi bana bülbül sesi gibi geliyor.)

mısralarına atıf yapan Namık Kemal, mana denizinin gayretinin gönlü, dünyayı dolaşan gemisi haline getirdiğini söyler. Gönül mana denizinde dolaşır. Baki’nin sürahinin ağzından dökülen şarap sesini bülbül sesine benzetmesi de mana denizinden bir kesittir. Her şeyden, her mekândan bir anlam çıkartılması şairin kabiliyetinin de bir göstergesidir.

Şeyhülislam'ın “duymasın” redifli gazelinde geçen;

Yâr derken kimseler râz-1 nihânın duymasın

Başladın feryada ey dil nevcevânım duymasın

Şeyhülislam Yahya'nın şairin sevgiliye seslenirken sırrını kimse duymaması konusundaki istek, Namık Kemal'de şairin kendisini merkeze alması şeklinde görülür. "Kendini sevgiliye öyle bahşet ki kendi cismini sonsuza kadar yok et, kabir taşında bile ismini görmesin senden bir nâm, nişan duymasın." ifadeleri ile Namık Kemal, sevgili yolunda kendi varlığından vazgeçmiştir. Bu beyitteki anlam ve söyleyiş ustalığının özellikle altını çizmek gerekir. Fuzuli'nin gazellerine yazdığı Tasavvufî anlamla yüklü nazirelerde daha zayıf kalan şair, Şeyhülislam Yahya'nın şiirlerindeki anlam ile daha yakın bir duygudaşlık ve söyleyiş birlikteliği içindedir.

\section{2) 17.yy. Şairlerine Yazılan Nazireler}

Namık Kemal'in de içinde yer aldığı Encümen-i Şuara şairleri eskinin canlandırılması ve savunulması amacını taşımaz. Onların asıl amacı "XVIII. ve XIX. asırlarda ayağa düşüp sı̆̆, hafif ve niteliksiz bir lâf canbazlığına dönüşen yeni şiiri eski ihtişamına kavuşturmak, "inhitat şairleri"ne muhalefetle, yeni şairi yüksek değerlerle donatmak hevesindedir." (Özgül, 2014: 47) Encümen şairlerinden başı çeken Leskofçalı Galip Bey'in bu konuda bulduğu çare "inhitat"tan hemen öncesinde büyük şairlerin yüksek şiirlerinin reprodüksiyonlarını yapmaktır. Namık Kemal de bu anlayışa uygun hareket eder. Bu dönem şairlerinden özellikle Naili'nin gazellerine nazireler yazar. Naili'nin gazellerinin tercih edilmesinin nedeni konusunda Hersekli Arif Hikmet Bey'in bir mektubu açıklayıcıdır:

"Şuarâ-yı muâsırînimizden Leskofçalı İsmail Paşa-zâde müteveffâ Galib Beyefendi ki, gerek ben ve gerek (diğerleri) kendinden telemmüz ederek nev-heveslik zamanımızda her ikimizin üstâdı idi. Üstâd-1 mşarünileyh Cevdet-i kariha, Cevdet-i mahfûzat ile hâsıl olabileceğinden ve Nâili ciyâdet-i lafz ü mânâ itibarıle pek mümtaz bir sühanver olduğundan onun mesleğine taklîdi tavsiye buyururlardı." (Ârif Hikmet, 1334: 16) 
Naili’nin gazellerini öncelikle Leskofçalı Galib Bey tanzir eder. Encümenin diğer şairleri ondan sonra aynı gazeli tanzir ederek, Naili'nin şiirinin asra uyarlanışını öğrenirler. Namık Kemal, Bâki'nin de yazdığ 1 "bana" redifli gazeli tanzir eder. Naili'nin "göğsüm sevginin gül bahçesi, iniltim bülbüldür, gönlümde yara açtığın zaman bana gül mevsimidir." ifadeleri ile başlayan gazeli sevgiliye yazılan bir medhiyedir. Namık Kemal, bu gazeli Na't-1 Nebi olarak yazdığı gazelinde tanzir eder. Şair, gönlü bütün dünyayı dolaşan bir gemiye benzetir. Divan edebiyatının klasik mazmunları yerine Namık Kemal, daha somut benzetmelerle bir hayal dünyası kurar.

Naili'nin "bulunmaya" gazelinin matlaı şöyledir:

Bir veçhe nâzır ol ki naziri bulunmaya

Bir zülfe beste ol ki esîri bulunmaya (Naili Divanı)

Namık Kemal'in bu gazeli şöyle tanzir eder:

Bir şuha bende ol ki esîri bulunmaya

Bir feyze tâlib ol ki habîri bulunmaya (s. 275)

Necip Fazıl, zemin gazel ve nazireleri üzerine yaptığı değerlendirmede Naili'deki fevkaladeliğin Namık Kemal'de bayağılığa düştüğünü söyler (Kısakürek, 1940: 143). Tabi ki bu görüş bir edebiyat bilimcisine değil, kendine özgü bir söylemi ve söyleyişi olan bir şaire aittir. Şairler arasında bu şekilde stilistik bir farklılığın olması doğaldır. Naili'nin sevgiliye bakışı ile Namık Kemal'in bakışı arasında da bu anlamda derin bir farklılık vardır. Naili bir bakışın ve bir saç telinin hayranlığının benzeri olmamasından bahsediyor. Âşı ğın aşkta ve sevgiliye bağlılıkta tek olması arzulanan ve beklenen bir durumdur. Namık Kemal, bu beklentiyi daha önceki nazirelerde olduğu gibi somut ifadelerle dile getiriyor. Diğer nazirelerle kıyaslandığında bu gazelin söyleyiş güzelliği bakımından yetersiz kaldığını da söylemek gerekiyor.

Çarhtan şikâyet divan edebiyatının sık kullanılan mazmunlarından biridir. Âşık ve mâşuğa sürekli engel olan, onların kavuşmalarını erteleyen hatta ölümlerine neden olan en büyük engel olarak görülür. Naili de "etse de" redifli gazelinde;

Çerh merdüm küştür ey dil terk-i bîdâd etse de

Vâpesindir bir nefes ehl-i dili şâd etse de

mısralarında feleğin gönül ehlini ölmeden önce son nefesinde mutlu etse de ölüm kaçınılmazdır, anlamını vurgular. Namı Kemal bu gazeli tanzirinde somutlaştırır ve âş̧ı̆a zulm edeni zâlim olarak adlandırır. Zâlim her ne kadar âşığı gam âleminden kurtarsa da ona verdiği sadece ölümdür. Âşı̆̆ın kimseye mihnet etmeden ölmesi sevinilecek bir durumdur. Bu gazelde Namık Kemal, Naili'nin söyleyiş ustalığını taklit etmiş olsa da anlam olarak çok zayıf bir şiir atmosferi oluşturur.

"Her katresi”" redifli gazelde şarabın her katresini güneş 1şıltısı gibi görür. Naili ise daha sağlam bir hayal dünyası oluşturur. Şarabın her katresi gönül yaralarının ümidi, şarap değil aşkı sağlamlaştıran bir yıldırım gibidir. İki şairin matla beyitlerinde kullandığı mazmunlara yakından bakmak istiyoruz. Naili, şarabın her katresini "berk-i te'kîd"e benzetirken Namık Kemal "hurşîd-i âteş pîşe"ye benzetir. Aşk şarabının her katresinin bıraktığı etki olarak kıyaslandığında "berk-i te'kid", sağlamlaştıran bir şimşek, "hurşîd-i âteş pîşe" güneş ş̧ı̆̆ına göre daha güçlüdür. Söyleyiş ve ritim açısından da Namık Kemal'in "Mey değil hurşîd-i âteş pîşedir her katresi" mısra1, Naili'nin "Mey değil berk-1 te'kîddir her katresi" mısraına göre daha güçsüz kalmaktadır. Naili;

Girye kim deryâ-yi tufan pîşedir her katresi

Meve hîz oldukça âteş rîşedir her katresi 
matlalı gazelinde de aynı redifi kullanır. Burada göz yaşının her damlasının "deryâyı tufan pîş̧e" ye benzetilmesi Naili'nin söyleyiş ustalığının bir göstergesidir. Namık Kemal aynı beyiti "bâde" ile oluşturur. Aşk şarabını her katresi "fürûz-i şîş̧eye benzetir. Her damlası "hurşîd-i ateş pîşe"dir. İki gazel arasında da özne ve nesne arasında bir geçişlilik söz konusudur.

Naili'nin "gönül”" redifli gazelinde;

Nakş-1 hüsnün görüp âşüfte nihâd oldu gönül

Verziş-i âh ederek şu'le nijâd oldu gönül

mısralarında aşığın sevgilinin güzelliği karşısında çılgına döndüğü ve âh çekerek onun 1şığının tabiatına tâbi olduğu anlatılır. Namık Kemal'in bu gazeli tanziri diğer gazellere oranla daha başarılıdır:

Şûr-i sevdâ çekerek Kays vedâd oldu gönül

Bûy-i zülfün duyup âşüfte nihâd oldu gönül (sy. 326)

(Sevda coşkusu çeken gönül Kays'a dost oldu. Gönül, saçının kokusunu duyup çılgın bir âşık oldu.) Bu beyitte Namık Kemal söz ahengini ikinci beyitte çılgınca seven bir âşık ifadesini ilk beyitte Kays ile yani Mecnun ile eşleştirir. Bu da Namık Kemal'in hemen tüm şiirlerinde gördügüumüz somutlamanın güzel bir uygulamasıdır diyebiliriz.

"Peyda" redifli gazelinde Naili’nin "bırak gönüller saçlarını tel tel ağırlaştırsın da yanağının bahçesine baş aşağı birçok salkım söğüt ortaya çıksın"8 ve "gözünün bakışının neşeli dudağ ş̧ark1 söyleyince, kirpiklerinin her hareketi sihirli bir beste meydana getirir." ifadeleriyle bir güzel tasviri yapar. İlk beyitte sevgilin yüzünü gül bahçesine benzeten şair, sevgilinin saçlarını bu bahçeye sarkan sögüt ağacı dallarına benzetir. İkinci beyitte ise sevgilinin bakışının şarkı söyleyen bir dudağı andırması ve bu şarkının ritmi ile kirpiklerinin hareketlerinin beste yapması Naili'nin ahenk ve söyleyişteki ustalığının bir göstergesidir. Namık Kemal tanzirinde "sevgilinin saçlarının büyülü kokusu ortaya çıkınca mecnuna dönmüş aklı bile harekete geçirir." ve "Gözyaşı denizinde sevgilinin güzelliği aksedince baştan aşağı bütün uykuda olanları uyandırır, gökyüzünü ters yüz eder." ifadeleri ile Naili'den oldukça farklı bir hayal dünyası oluşturur. Naili'nin divan edebiyatının mazmunları ile oynayarak elde ettiği anlam, sevgilinin yüceltilmesi amacını gütmektedir. Ancak Namık Kemal sevgiliyi yüceltmek yerine daha çok sevgilinin güzelliğinin etkileri ve akisleri üzerinde durur. Naili’nin özneye yoğunlaştırdığı ilgiyi Namık Kemal nesne üzerinde yoğunlaştırır. Özneden nesneye bir geçiş söz konusudur.

Yaktım dili ateşlere tâb-1 nazarımdan

Berg-i gül-i ruhsârına dağım eserimden yaralıyım.)

(Bakışımın 1şıltısından gönlü ateşlere yaktım. Eserimden gül yanağının yaprağına

mısralarında Naili sevgiliye bakışının tesirinden bahsediyor. "Peydâ" redifli gazelden farklı olarak bu gazelde şair, sevgilinin kendi üzerindeki tesiri üzerinde durur. Namık Kemal de paralel bir düşünce yapısı içerisindedir. Sevda ateşinin 1şıltısı, ateşin iniltisi dünyayı cehenneme döndürür. Sevgilinin güzelliği üzerinde durmayan şair, âşığın sevgiliye duyduğu sevginin kendisini yakıp kül

\footnotetext{
${ }^{8}$ Girân itsün ko diller târ târ-1 zülfün olsun tek Ruhun bâğında nice müş̧g-i bîd-i ser-nigün peydâ

${ }^{9}$ Leb-i şûh-1 nigâh-1 çeşmûn oldukça terennüm-sâz

İder her cünbiş-i meüjgânı bir nakş-1 füsun peydâ
} 
ettiği üzerinde durur. Namık Kemal her ne kadar divan edebiyatı örneklerini kendisine rehber etmiş olsa da özellikle bireyselliğe önem verir.

Benzer bir anlatım "cünun" redifli gazelde de görülür. "Saçının teline çılgınca sevdalandığımdan beri ayaklara akıl zinciri engel olmaktadır." Sevgiliye olan aşk, aşığı deliye çevirir. Âşık bu hale geldikten sonra ise akıl bu sevdaya ayak bağı olur. Sevgili, nedensiz ve niçinsiz sorgulamadan sevilmelidir.

Olalı zülgüne hem silsile sevdâ-yi cünun

Oldu reşg âver-i zencîr-i hired pây-i cünun

Namık Kemal de aşkın âşık üzerindeki etkisini dile getirir. "Saçının telinin hilesi, çılgın sevdanın mayası olur. Böylece nice âşığı deliliğin rezilliği ile küfre sürükler.” Bu mısralarda Namık Kemal, Naili'nin sevdanın akıl ile engellenmesi, zincire vurulması imgelerini bir adım daha ileriye götürür ve sevgilinin saç telinin inkâra götürdüğünü söyler. Aşkın, ileri seviyelerinde âşı̆̆ı deliye çevirmesi divan şiirinin klasik anlatımlarından biridir.

"Görün" redifli gazelde Naili, gül ve bülbül mazmunları ile sevgili için güzelleme yapar. Goncanın açması, teşhis sanatı ile yakası açık bir sevgiliye benzetilir. Goncanın bu haline sen, şakrak bülbül feryat eder. Bu gazelde şair, sevgilinin âşık üzerindeki etkisine bütün âlemi şahit göstermek ister. Bülbül aşkı ile yanıp tutuşmaktadır. Aşk, âşı̆ğ kendinden geçirir. Namık Kemal, naziresinde Kerbelâ olayına telmihte bulunur. Hz. Hüseyin'in şehit olduğu yer "meşhed" âşıkların gönlünde onulmaz yara açmıştır. Burada şehit olanların hali, âşıkları keder içinde bırakmıştır. Naili’nin sevgilinin hâli karşısında âşı̆̆ın içinde bulunduğu durumu tahayyülü karşısında Namık Kemal, tarihî bir olay karşısında âşıkların içinde bulunduğu duruma âlemi şahit tutmak ister. Şairin Kerbelâ olayına atıfta bulunması daha somut bir acının kendisinde uyandırdığı duyguyu diğer insanlarla paylaşması bakımından önemlidir. "Hep" redifli gazelde de benzer bir anlatım söz konusudur. Sevgilinin bakışları şairin gönlünü çılgına döndürür ve her an gönüldeki yaralar tekrar tazelenir. Naili'nin bu gazelinde de âşı̆̆ı̆n sevgilisinden gördüğü ilgi karşısında kendisinde oluşan yara, acı ve keder söz konusudur. Namık Kemal, Naili'nin bu gazelini anlam olarak aynen tekrar eder. Matla beytin ikinci mısraı Naili'nin şiirinden alıntıdır:

Sad pâre edüp sinemi nezzârelerin hep

"Her lâhzada bir tazelenir yârelerin hep" (sy. 366)

Naili'nin Tasavvufî aşk1 anlattığı "et”" redifli gazelinde;

Aşkınla İlâhi beni aşüfte dimâğ et

Şeb tâ be seher hem nefesim dûd-i çerağ et

mısralarında İlahî aşk ile çılgına dönen bir akıl isteyen şair profili çizilir. Akşamdan sabaha kadar nefesinin kandil dumanı gibi göğe çıkması isteği söz konusudur. Şair, nefesini kandil dumanına benzetirken kendisi de çıra gibi yanmaktadır. Aşk ateşiyle sabaha kadar yanan İlahî aşkla deliye dönmüş bir âşık resmi çizilir. Namık Kemal, Naili'nin “dûd-i çerağ” mazmununu biraz daha açar:

Her zerremi mihrinle Hudâ mahşer-i dâğ et

Her dâğımı tâ subh-i kıyâmette çerâğ et (sy. 409)

Naili'nin akşamdan sabaha kadar yanan kandil mazmunu, Namık Kemal'de kıyamete kadar İlahî 1şıkla yanacak bir kandile dönüşür. Burada iki şair arasında bir duygu ortaklığı açıkça görülmektedir. Benzer bir örnek de "gideriz" redifli gazelde vardır. Naili’nin;

Hevây-i aşka uyup kûy-i yâre dek gideriz 
Nesim-i subha refîkız bahâre dek gideriz

gazeli bu tarzda yazılan ilk gazeldir. Aşk, sevgilinin bulunduğu yere âşığı sürükler. Naili’de sabah rüzgârına dost olan şair bahara kadar, her yer gül bahçesi olana kadar gider. Namık Kemal de ise aşkın, âşı̆̆ı deli divane etmesi ile sevgili neredeyse oraya kadar gider. İki gazel arasında zaman ve mekân farklılığı söz konusudur. Namık Kemal, zamanı aradan çıkartarak sadece mekânsal ve somut bir birlikteliği arzular.

Namık Kemal'in 17.yy. şairleri arasında nazire yazdığı diğer bir şair Fehim-i Kadim'dir. Fehim-i Kadim şiirlerinde genel olarak kendi iç dünyasını, düşünce yerine muhayyileyi, dış dünyadan çok insanın heyecan ve kederlerini konu edinir. Şairin en büyük özelliği kendine has bir üslup sahibi olmasıdır (Üzgör, 1995: 295). Namık Kemal nazire yazdığı şairleri seçerken özellikle üslup konusunda kendine has bir tarz geliştiren ve divan edebiyatına bu anlamda katkıda bulunan şairleri özellikle tercih eder. Fehim-i Kadim’e yazdığı nazirelerde bu özelliği görmek mümkündür.

Fehim' in tevhid olarak kaleme aldığı "bana" redifli gazelin matlaı şu şekildedir:

Ey vücudun pertevindendir adîm olmak bana

Vâcib oldu sâye-i kadîm olmak bana

(Ey vücud, bana fakir olmak senin ışığındandır. Bana ayağının gölgesi olmak vacib oldu.)

Allah'ın varlığı karşısında insan acizliği ile vardır. Tasavvufta insanın Allah'ın bir gölgesi olduğu, varlığının Allah'ın isimlerinin bir tecellisi olduğu inancı söz konusudur. Fehim, tevhid gazelinde bu inancı dile getirir. Namık Kemal tanzir ettiği bu gazelde tevhid düşüncesini işler. Kadîm olmanın sırrı Allah'ın kudretine dayanmakla olur. Yoksa yaratılıştan itibaren fakir olmak şair için vaciptir. İnsanın varlığının Allah'ın bir tecellisi olduğu inancı her iki şairde de benzer şekilde işlenir. Fehim "sâye-i kadim" mazmunu ile sonuç üzerinde dururken Namık Kemal bu sonuca ulaştıran sebep üzerinde durur. "Sâye-i kadim" olabilmenin sebebi şairde "istinâd-1 kudret" ile açıklanır.

Fehim gazellerinde özellikle iç dünyasını konu edinir. "âftâb" redifli gazelinde şair, sevgiliye nazar ettiğinde kendisi üzerindeki aydınlatıcı etkisinden bahseder. "Ruh-i mâh" ve "tâb-1 nigâh" sevgilinin yüzü ve bakışı ile ilgili divan edebiyatında sık kullanılan teşbihlerdir. Namık Kemal tanzir ettiği bu gazelde terkiplerden kaçınır ve daha sade bir dil kullanır:

Pertev gedadır ol yüzü mâhımdan âftâb

Olsun hakîr baht-1 siyahımdan âftâb

Ay yüzlü sevgilinin 1şığından yararlanamayan şair, kara talihinin güneşi bile karartmasından şikayetçidir. Fehim'in sevgili çerçevesinde oluşturduğu hayal, Namık Kemal de daha sade bir şekilde yer alır.

"Bana" redifli gazelde Fehim;

Bir hayat içün kazâ bilmem ne nâz eyler bana

Ben şehîd-i gamzedeyim Îsâ naz eyler bana

mısralarında kaderci bir yaklaşım sergiler. "Şehîd-i gamzede" olan şair, Hz. İsa'nın ölüleri diriltme mucizesine telmihte bulunur. O'nun mucizesi bile şairi diriltmekte nazlanır. Akıp giden hayatta kader ne yazdıysa bu kaderin gerçekleşmesi bile nazlıdır. Şair, karamsar bir ruh halindedir. Çaresizlik ve içinde bulunduğu durumdan kurtulamamanın bir sorgulamasıdır. Namık Kemal ise zaaflarının farkındadır. Bu zaaflarla da gurur duymaktadır. Dünyanın nazlanması da bu zaaflardan kaynaklanmaktadır. Sevgilinin gözü olup dünyayı sevgilinin gözünden seyreden şair, kaderin tecellisinin kendisi için niyazda bulunduğunu söylüyor. Fehim'in kaza karşısındaki çaresizliği, 
Namık Kemal'de kendisi için niyazda bulunan bir hale bürünür. Yine Fehim çektiği aşk acısı ile şehid olurken, Namık Kemal, kendi varlığı ile sevgilinin varlığını birleştirir. Tek vücud olarak dünyayı seyreder. "Kaza" redifli gazelde de benzer bir anlam söz konusudur. Fehim gazelinde "çeşmi mestinde iyan nükte-i pinhânı kaza" mısraında kazanın tecellisini sevgilinin mest olmuş gözünde görür. Kader, âşığın hayatını sevgilinin bakışında derç etmiştir. Bu kazanın gerçekleşmesindeki işaret ise sevgilinin gamzesinde saklıdır. Namık Kemal, âşığın sevgilinin gamzesinde gerçekleşen kaderden ağladıkça kaza meclisinin feryadı ile sarsılır, der. Her iki şairde de sevgilinin gamzesi kaderin tecelli ettiği noktadır. Sevgilinin yan bakışı, âşık için kaderin tecelli ettiği noktadır. Namık Kemal'in tanzir ettiği bu iki gazelde kurduğu hayal dünyasının oldukça başarılı olduğunu belirtmek istiyoruz. Namık Kemal'in şairlikteki başarısı bu iki gazelde daha net fark ediliyor. Namık Kemal'in aynı başarıyı gösterdiği diğer bir tanziri de "olarak" redifli gazeldir:

Etme 1zhâr-1 vefâ çevre peşîmân olarak

Garazın lûtf ise öldür beni ihsân olarak (sy. 433)

(Pişman olarak vefanı gösterme, amacın lütfetmek ise ihsan olarak beni öldür.)

Sevgilinin elinden ölmek âşık için en büyük lütuftur. Sevgilinin elinden ölme isteği, âşığın kendini sevgilide yok etme isteğinin bir sonucudur. Fehim, sevgiliden uzak düşmenin acısını, kederini dile getirir. Gözyaşı, acının ve kederin somut bir göstergesidir. Bu acı da şair için bir lütuftur.

Fehim'in tevhid olarak yazdığı "dilimizdir" redifli gazelindeki "ser kafile-i âlem-i ulvî dilimizdir" mısraı ile Namık Kemal'in "Deryâ-yi füyûzât-1 ilâhi dilimizdir" mısraı aynı ifadenin farklı söyleyişinden ibarettir. Gönül, İlâhi feyizlerin deryasıdır. İnsanın yaratılış itibariyle Allah'ın bir tecellisi olduğu anlamı her iki şairde benzer şekilde ifade edilmiştir.

Aşkın şairin iç dünyasındaki yansımasını konu edinen diğer bir gazel "nâbedîd" redifli gazeldir. Fehim'in kendine has üslubunun daha net görüldüğü bu gazelde matla beyitte iç derinlik söz konusudur:

Dilde bir deryâ yatur ki ka’r ü sâhil nâbedid

$\mathrm{Bu}$ acebdir olmuş anda yine hem dil nâbedîd

(Gönülde bir derya yatar ki derinliği de sahili de belirsizdir. Bu acayip bir şeydir. Ama onda gönül de belirsizdir.)

Gönülde uçsuz bucaksız deryâ ile bu deryanın bulunduğu gönlün belirsiz olması bir tezattır. Ancak derya ve gönlün birbiri içinde kaybolması ve belirsizleşmesi külli iradede eriyen cüz'i iradenin bir ifadesidir. Namık Kemal de benzer bir anlam vurgusu yapar:

Sînede envâr-1 hüsnün müncelî dil nâbedîd

Pertev-i hurşîd rûşen z1ll-i zâil nâbedîd (sy. 288)

İki şair de Allah'ın ebedi nurunun gönülde tecellisi ile fani gönlün belirsizleştiği anlamını vurguluyor. Allah'ın nurunun insanda tecellisinin insan tarafından fark edilmesi ve kendi varlığını O'nun varlığında eritmesi insandan beklenir. Kendi varlığını İlahî varlıkta eritebilenler ise âşıklardır. Fehim, gönlün belirsizleştiğini belirtirken Namık Kemal de fâni olanın gölgesinin bile belirsizleştiğini külli iradede yok olduğu anlamını konu edinmektedir.

"bize" redifli gazel Fehim'in en çok bilinen ve en çok tanzir edilen gazellerinden biridir:

Gonca-i âteş nesimiz âh düşmendir bize

Bülbül-i pervâne tab'ız şu'le gülşendir bize 
(Biz ateş soluklu goncayız, âh bize düşmandır. Işıkla yanan kelebek yazgılı bülbülüz, alev gül bahçemizdir.)

Gonca, açılmamış gül, gülün henüz yapraklarını açmamış hali, gül tomurcuğudur. Divan edebiyatında sevgilinin ağzına benzetilir. Gonca açılmamış hali ile gizemini saklayan ele vermemiş bir sevgili ile özdeştir. Fehim de gazelinde kendisini sevgilinin varlı̆̆ında yok etmiş ve ateş soluyan ağızdan âh çıkmayan bir âşığa benzetir. Pervâne geceleri ışı̆̆ın etrafinda dönen küçük kelebektir (Ayverdi, 2016: 990, 1163; Sungurhan-Eyduran, 2006: 392; Devellioğlu, 2013: 1008). Simgesel olarak da pervâne âşığı temsil eder. Âşık için, sevgili kendisini yakan, yok eden bir ışık, gül bahçesidir. Namık Kemal, Fehim'in gonca ile vasıflandırdığı sevgilinin âşık üzerindeki tesirinden bahseder. Gönül yarası, sevgilinin cilvesidir ve âşık için aydınlıktır. İki gazel arasında sevgilide hemhâl olmak ortak bir duygudur.

"Dûzah" redifli gazelde Namık Kemal, Fehim'in üslubunu taklid eder:

Ya Râb dil-i pür sûzum edüp mâye-i dûzah

Et berk-i gül-i dâğımı pîrâye-i duzah

(Ya Râb, ateş dolu gönlümü cehennemin mayası yapıp gül gibi yaramın şimşeğini cehennemin süs yap)

Yâ Rab şerer-i şevkım edüp vâye-i dûzah

K1l âh-1 cihansûzumu sermâye-i dûzah (sy. 307)

(Ya Rab, şevkimin kıvılcımını cehennemin nasibi edip dünyayı yakan âhımı cehennemin sermayesi yap.)

Fehim'in "dil-i pür sûz" ifadesi ile "şerer-i şevk" arasında bir anlam birliği söz konusudur. Her iki beyitte de şairlerin ortak duygusu sevgilinin ayrılık acısıyla yanan gönlünün cehennemin mayası olacak kadar büyük olduğudur. $\mathrm{Bu}$ gazel, şairlerin iç dünyasındaki hissiyatı anlaşılması bakımından oldukça önemlidir. Namık Kemal'in tanzirinde ise farklı bir hissiyattan bahsetmek mümkün değildir. Şair sadece aynı anlamı, aynı düzlemde yeniden ifade etmekle yetinir.

Divan şiirinde Hz. İsa birçok şiirde konu edilir. Hz. İsa'nın babasız olarak yaratılması, bebekken konuşmas1, kendine İncil'in verilmesi, Hz. Muhammed'in geleceğini müjdelemesi, mucizeleri, özellikle ölüleri diriltme mucizesi ve Allah'ın katına yükseltilmesi gibi olaylara atıf yapılır. Hz. İsa divan şiirinde Mesih, Mesiha, Ruhullah, Ruhu'1-Kudüs, İbn Meryem gibi sıfatlarla anılır. Genellikle de şairler Kur'an-1 Kerim'de Hz. İsa ile ilgili verilen bilgilere bağlı kalırlar (Koçin, 2009: 74). Fehim'de bu geleneğe uyarak "Mesih" redifli bir gazel yazar:

Hatt-1 lâ'linki odur hüccet-i i'zâz-1 Mesîh

Bârekâllah zehî nüsha-i i'câz-i Mesih

(Mesih'in yüceliğinin delili kırmızı dudağının hattıdır. Allah mübarek etsin bu Mesih'in mucizesinin bir nüshasıdır.)

Sevgili dudağından soluduğu nefesi ile ölüleri dirilten Mesih'e benzetilir. Fehim de bu anlamı vurguluyor. Hz. İsa'nın ölüleri dirilten mucizesi gibi sevgili de âşığa dudağı ile hayat vermektedir. Namık Kemal tanzir ettiği gazelinde Fehim'in mazmunlarla verdiği anlamı daha açık bir üslupla dile getirir:

Reşg eder lâline can vermede i'câz-1 Mesîh

Ey dem-i feyz eseri mâye-i i’zâz-1 Mesîh (sy. 307) 
(Mesih'in mucizesi bile senin dudağının can verici olmasını kıskanır. Ey bereket nefesi, eserin Mesih'in yüceliğinin mayasıdır.)

Sevgilinin gamzesinin konu edildiği diğer bir gazel de "şûh" redifli gazeldir:

Nedir bu gâviş-i nîş-i itâb-1 gamze-i şûh

Cihan cihan dili ettin harâb-1 gamze-i şûh

Sevgilinin gamzesi âşık için öldürücü bir iğne gibidir. Sevgilinin bir bakışı ile âşı̆̆ı öldürecek gibi olur. Bu gazelde Fehim, gamzeyi öldürücü bir iğneye benzetir. Namık Kemal de sevgilinin bakışının verdiği ızdırabın kazayı titrettiğini söylüyor. Sevgilinin gamzesinin âşık üzerindeki öldürücü etkisinden şairler şikâyet eder gibi görünse de aslında bu onların istediği beklediği bir şeydir.

\section{Namık Kemal'in;}

Hecr ile mâh-1 muharremdir felekte kevkebim

Kisve-i mâtem çeker dûş-i cihana her şebim (sy. 329)

Ayrılı̆̆ın şair üzerinde etkisi üzerinde duran Namık Kemal, kendisindeki ızdırabı bütün dünyaya mâl eder. Bu şairin bakış açısı ile ilgilidir. Âşık öyle bir haldedir ki kendi karamsarlığı nedeniyle dünyayı da bu karamsarlıkla seyreder. Namık Kemal'in tanzir ettiği Fehim'in gazelinde ise Namık Kemal'den farklı olarak karamsarlık hâkim değildir. Şair, sevgilinin gece karanlığını nuru ile aydınlattığını söyler. Fehim için sevgiliden ümit kesilmez.

Âşı̆̆ın sevdasından deliye dönmesi ve çoğunlukla da Mecnun'a benzetilmesi divan şiirinde sıklıkla işlenen bir konudur. Fehim de bu mazmunu birçok şiirinde kullanır. Bir şiirinde de "cünun" kelimesini redif olarak kullanır:

Aklıma etti şebîhun yine sevdâ-yi cünun

Tuttu mülk-i hiredi şûrişi gavga-yi cünun

Aşk acısının özellikle yalnızlıkla birlikte gece vakti âşı̆̆ı karamsarlığa sürüklediği bilinmektedir. Aşk, duyguların yoğun olarak çalıştığı, aklı devre dışarı bıraktığı bir ruh halidir. Namık Kemal de Naili tarafından da yazılan aynı redifli gazele yaptığı tanzirinde şiirin tamamında özellikle aşkın kendisini deliye çevirdiği Mecnun'a (Kays) telmihte bulunur. Namık Kemal'in bu telmihleri onu divan şiiri mazmunlarına ve dünyasına bağlayan unsurlardır.

Fehim şiirlerinde genellikle kendi iç dünyasını yansıtmıştır. Ancak zaman zaman geleneğin düşünce yapısına uygun olarak sevgili tasvirleri de yapar. "Görün" redifli gazelinde sevgilinin konuşmasını ve onun gizli lütuflarını herkesin görmesini ister. Bu istek şairin ruh dünyasının bir dışa vurumudur. Namık Kemal de bu geleneğe uyarak tarihteki ünlü olaylara telmihte bulunur. Kerbela olayı, Yakub ve Yusuf kıssası, Hz. İsa, Hz. Yahya şiirde telmihte bulunulan belli başlı olaylar ve isimlerdir. Örnek olarak bir beyit almakla yetineceğiz:

Pâktir reng-i beyâz-1 dîde-i Ya'kub'dan

Ol meh-i Yûsuf cemâlin tarf-1 dâmânın görün (sy. 364)

Namık Kemal yaptığı tanzirlerde genellikle tanzir ettiği gazelden daha sade bir dil kullanırken bazı şiirlerinde ağır terkipler de kullanır. Örnek olarak aldığımız beytin ilk mısraında dörtlü bir terkip Namık Kemal'in çok başvurmadığı bir kullanımdır.

"Olur" redifli gazelde Fehim, sevgilinin gözyaşının ona bakanlar için onları yeniden dirilten bir emir gibi olduğunu söyler. Sevgilinin bir bakışının âşığa hayat vermesi, bir busenin gül bahçesine 
çevirmesi sevgiliye verilen önemin bir göstergesidir. Âşı ğın hayatını güzelleştiren, süsleyen sevgilinin ona ilgi duymasıdır. Namık Kemal bu anlamı daha zarif bir şekilde ifade eder:

Korkarım hûn-i serim lekke-i dâmânın olur

Yoksa bin cân ile dil küşte-i müjgânın olur (sy. 398)

(Başımın kanının eteklerini lekelemesinden korkarım. Yoksa bin can senin kirpiklerinde can versin.)

Sevgili için can vermek âşık için büyük bir mutluluktur. Âşı seve seve sevgili için canını vermeye hazırdır. Ancak Namık Kemal bin can olsa da bunu sevgili için feda etmeye hazır olduğunu belirtirken verdiği canla birlikte çıkan kanın sevgilinin eteğini kirletmesinden endişe eder. Bu divan şiiri açısından zarafet ve nezaketin bir ifadesidir.

Fehim'in aynı redifli bir gazelini de Namık Kemal tanzir eder. Sevgilinin bakışı üzerinde durulan matla beyitte âşığın âhı cehennemin ışığına benzetilir. Âşığın âhı ile cehennemin yakıcı 1şığı arasında kurulan bağ, âşığın aşkının da bir ifadesidir. Sevgilinin bir bakışı ile 1zdırap çeken âşığın acısı cehennemin vereceği acı ile eşdeğerdir. Namık Kemal aynı anlamı sevgilinin yüz güzelliği ve bakışı ile tanımlar.

Hayret-i berk-i cemâlinden ki dil bîhuş olur

Nûr-i çeşmim Pertev-i Tûr ile hem âgus olur (sy. 400)

Bu beyitte sevgilinin gözünün nurunun Tûr dağında Hz. Musa'nın Allah ile konuşmasına benzetilmesi de orijinal bir benzetmedir. Âşık ve mâşuk arasındaki aşkın ulaştığı son nokta olan bu benzetme Namık Kemal'in divan şiirinde ulaştığı noktayı göstermesi bakımından da önemlidir.

Fehim'in "peymânemiz" redifli gazelinde divan şiirinde sıklıkla görülen "bâde, Mecnun, sâki, meyhâne" mazmunlarına yer verilir:

Bâde-i aşkız dil-i Mecnun'dur peymânemiz

Akl-1 kül olsa revadır sâki-i meyhânemiz

Peymâne, divan şiirinde kadehin eş anlamlısı olarak kullanılır. Tasavvufta kadeh içindeki şaraba istinaden manevî hâl, ruhiz haz, şevk, cezbe ve vecd anlamlarını karşılar (Uludağ, 1996: 291; Ceylân, 2004; 5-6). Mecnun da âşı̆̆ın en önemli örneğidir. Beyitte Mecnun'un gönlü, aşk şarabının içildiği kadehe benzetilir. Bu iki mazmunun bir arada kullanılması şiiri güçlendirmiş ve söyleyiş güzelliği katmıştır. Böyle bir içkinin sunulduğu meyhanede içki sunanlar da aklı başında olmayan kişilerdir. Âşıkların toplandığı ve aşk şarabı içilen bir meclis tasviri yapılıyor. Namık Kemal de tanzir ettiği bu şiirde âşık meclisini tasvir eder. Meyhane aşk sarhoşu ile dolu bir meşheddir ve son sarhoş narası ölüm anında verilen son nefestir. Şiirde şair, aşk acısı çeken âşıkların hâlini ölümü bekleyen şehitlere benzetir. Aşkı için ölen âşıktır bir nev'i şehittir. Fehim'in âşıkların mekânını, Mecnun gönüllü âşıklarla dolu bir şekilde ifadesini Namık Kemal âşıkların mekânını şehit meydanına benzetir:

Mest-i aşkız meşhed-i âşûbdur meyhânemiz

Vâpesin âh-1 eceldir na're-i mestânemiz (sy. 417)

Sevgilinin âş̧ı üzerindeki etkilerinin tasvir edildiği diğer bir şiir de "sinemiz" redifli gazeldir:

Aks-i hüsn-i yâr ile pürdür derûn-i sinemiz

Nûr bahş-1 dîde-i hurşîddir âyînemiz 
(Sinemizin derinlikleri sevgilinin güzelliğinin aksi ile doludur. Aynamız güneş gözlünün nurunun lütfu ile doludur.)

Sevgilinin bakışı, âşık için büyük bir lütuftur. O bakış ile âşık yaşama tutunur. Çeşitli mazmunlarla dile getirilen bu bakış, sevgilinin âşığa ilgisinin devam ettiğini gösteren bir işarettir. Namık Kemal, aşk ızdırabının iç dünyasındaki yansımasını konu edinir:

Zerre bahş-i dâğ-1 gamdır 1ztırâb-1 sinemiz

Âftâb-1 mahşeri raksân eder âyînemiz (sy. 417)

Şair aşk ıztırabını sevgilinin bir lütfu olarak görür. Bu 1ztırabın zerresi bile mahşer güneşinin raks ettirir. Fehim, sevgilinin gözündeki nuru güneşe benzetirken, Namık Kemal mazmunu değiştirerek mahşer güneşi ifadesini kullanır. Her iki beyitte anlam ve söz gücü itibariyle benzerlik göstermektedir.

Hz. Ali, divan şiirinde pek çok sıfat ve unvanla anılır. İlim, fütüvvet (kahraman), mürüvvet (yardımsever), fazilet örneği olarak kullanılır. Fehim "hâkimiz" redifli gazelinde Hz. Ali'nin feyzinin ağır başlılığının mayasını oluşturduğunu ifade eder:

Bâğ-1 hüsnüz sûde-i hurşîddendir hâkimiz

Sâye-i feyz-i Âli'dir mâye-i temkinimiz

Güzellik bahçesinin toprağı güneşin ezilmiş halinden oluşur. Güzellik bahçesinin toprağının güneşten oluşması olgunluğun bir ifadesidir. Bu olgunluğun temelini de Hz. Âli'nin feyzidir. Namık Kemal aşk gül bahçesinin zemininin Tûr dağının toprağı ile kaplı olduğunu söyler. Tecelli bahçesinin goncası yüz parça olmuş gönle benzetir. Tûr dağı, Hz. Musa'nın Allah'la bizzat görüştüğü yerdir. Allah burada Tûr dağına tecelli etmiştir. Allah'ın yer yüzünde açıkça tecelli ettiği Tûr Dağı da bu anlamıyla divan şiirinde sıklıkla kullanılır. Sevgilinin bir ilgisini bekleyen âşı için de bu ilgiyi gördüğü yer, Tûr dağ 1 gibidir. Âşıkla mâş̧ukun kavuşma yeridir. Ancak şair bu tecellinin kendi gönlünde gerçekleştiğini söyler. Maddi olarak Tûr dağında tecelli eden Allah, âşığın gönlünde tecelli etmektedir.

Fehim'in şiirlerinde iç dünyasını anlattığını belirtmiştik. "Gurbetiz" redifli gazelinde de şair iç dünyasındaki dalgalanmaları ifade eder:

Geh mevc veş misâfîr-i ummân-1 gurbetiz

Geh girdibâh-1 bâdiye gerdân-1 gurbetiz

Şairin ruh hâli gurbet denizi ile çöl arasında gidip gelmektedir. Bazen coşan bazen de yanan, suskunlaşan bir ruh hali, âşığın genel ruh halini belirtir. Bu gidip gelmelerden âşık memnundur. Bu hâl kalp ritmi gibi iniş ve çıkışlarla âşık için hayat belirtisidir. Namık Kemal, gurbeti anlatırken Hz. Yusuf'un atıldığ 1 Kenan kuyusuna telmihte bulunur. Hz. Yakup'un oğlu Hz. Yusuf'a olan özlemi ve ondan ayrılığı, gurbeti en ünlü hadiselerden biridir. Namık Kemal, gurbet duygusunu Hz. Yakup ve $\mathrm{Hz}$. Yusuf arasındaki gurbet hadisesine ve gurbet hüznünün kulübesi ile ifade eder. Fehim'in coşku ve sakinlik arasındaki denge Namık Kemal'de yer almaz. Namık Kemal gurbet hüznü üzerinde durur.

"Henüz" redifli gazelde ise Fehim padişah ve askerin azledilmiş olmasına rağmen hala gururlu olduğunu, hat gelse de kirpiğin hâla yüz kir içinde olduğunu söyler. Divan şiirinde kirpik askere benzetilir. Sevgilinin kirpikleri, âşık için bazen hançer gibidir. Azledilmiş asker gibi olsa da hâlâ o gururlu hâli devam etmektedir:

Oldu ma'zul o şeh ü leşkeri mağrur henüz

Gerçi hat geldi müje bâis-i sad henüz 
Namık Kemal, Fehim'in şiirinde görülen mazmunları kullanmaz, daha sade bir dil kullanır:

Can fenâ buldu dil âteşzede-i nûr henüz

Yandı Mûsâ serer efzâ görünür Tûr henüz

Şair, iki zıt durum üzerinde durur. Can ölse de gönül nur ateşi ile kavrulmaktadır. Musa yansa da Tur dağı hayret vermeye devam etmektedir. Sevgilinin aşkı, âşı̆̆ın fâni vücuduyla bağlı değildir. Her şey geçip gitse bile sevgilinin tecellisi âş̧kta görünmeye devam eder. Bu tanzirin de şairin başarılı şiirlerinden biri olduğunu belirtmek istiyoruz.

17. yy. şairlerinden Nabi "hikemi tarz" olarak bilinen anlayışın en önemli temsilcisi kabul edilir. Şair, hikemi tarzı kendine özgü şiir anlayışı, üslubu, tutumu ve konu seçimleri ile özgün bir yere sahiptir (Gültekin 2013, 95-116). Nabi'nin öne çıkan bu özelliğine rağmen Namık Kemal, şairin bu özelliğini almaz. Şairin sadece 3 şiirini tanzir eden Namık Kemal, seçtiği şiirlerde anlam derinliğine önem verir. Nabi'nin didaktik ve tenkitçi şiir anlayışından uzak duran Namık Kemal, tanzir ettiği şiirlerde daha çok onun şiir sanatından ödün vermeyen özelliğinden ve dilinin yalın, süssüz olmasindan faydalanmak ister.

Namık Kemal'in Nabi'nin şiirlerinden ilk tanzir ettiği şiirde Nabi bir bayram sabahını tasvir eder. Bayram sabahı çocukların gülmesini sağlayan bir zamandır. Ancak bu sevinçli zaman, anlaşılması dikkat isteyen şeylerle baştan başa kilitlenir. Bayram sevinci, hüzne döner. Sevinç ve hüznü aynı ana sığdıran şair, çocukların sevincini bir anda bozan inceliklere dikkat çeker. Namık Kemal şiirinde daha somut sebepler gösterir:

Çekilmez bir belâdır bâr-1 derd-engizi emvâlin

Olur, feryâd her dem ol sebebden kârı dellâlin (sy. 359)

(Mal ve mülkün dert veren yükü çekilmez bir beladır. Tellalın kârı da her zaman bu sebepten dolayı feryat etmesinden olur.)

Nabi'nin şiiri ile Namık Kemal'in tanziri anlamdan daha çok söyleyiş özelliği bakımındandır. İlk mısrada yüklemle başlayan cümle her iki şiirde de cümlenin diğer öğeleri ile devam eder. İkinci mısrada Namık Kemal, yüklemi yine başa alarak mısranın kesinlik anlamını pekiştirir. Nabi'nin beyit bütünlüğüne verdiği önem, Namık Kemal'de de devam eder. Nabi'nin beytinde "sabah-1 id, efvah, dekaik, dehan" kelimeleri ile oluşturduğu anlam bütünlüğü ve ahenk, Namık Kemal'de "belâ, bâr-1 derd-engiz, feryâd, kâr, dellâl" kelimeleri ile sağlanır.

Nabi'nin ikinci gazelinde gam ve keder için sebep aranır:

Ne sendendir ne bendendir ne çarh-1 kînerverdendir

Bu derd-i ser humâr-1 neşve-i kederdendir

( $\mathrm{Bu}$ başın derdi ne senden ne benden ne de kin besleyen felektendir, kederin neşeli sarhoşluğundandır.)

Hüzün, gam ve keder divan şiirinde istenilen bir şeydir. Şairin istediği mutlu olmak değil, hüzün neşesini yaşayabilmektir. Şair, kederin sebebini dışta aramak yerine sebep-sonuç ilişkisi içerisinde sebebi de sonuca bağlar. Sebep de sonuçta kederdir. Namık Kemal de;

Ne hükm-i devr-i ahterden ne hurşî̀d ü kamerdendir

Cefâ âdât-1 âlemden sitem hulk-i beşerdendir

mısralarıyla cefanın eziyetin sebebini dış sebeplerde değil insanın kendisinde bulur. Cefanın sebebi yıldızlardan, güneşten ya da aydan değil, insanların âdetlerindendir. $\mathrm{Bu}$ nedenle felekten dert 
yanmanın anlamı yoktur. Bu iki beyitte aynı anlam etrafında oluşturulan bir anlam birlikteliğinden bahsedebiliriz. Divan şiirinde felekten dert yanma ortak bir mazmun olarak kullanılır. Bu iki beyitte ise soyut bir kavramı suçlamak yerine somut varlık telaffuz edilir. Nabi de sadece kederin verdiği neşe söz konusu iken Namık Kemal devrine uygun olarak devrin ahlak anlayışından sitem etmektedir. Bu gazel, Nabi'nin hikemi tarzına daha uygundur.

Hz. Âdem ve Havva'ya gönderme yaparak aşk temini işleyen Nabi;

İrtibât-1 hüsn ü aşk olmuştu müstahkem henüz

Turra-i Havvâya dilbend olmadan Âdem henüz

mısralarında Hz. Âdem'in Hz. Havva'ya aşık olmadan güzellik ve aşk ile tanıştığı belirtiliyor. Hz. Âdem'in bir insana olan aşkından önce Allah aşkını tanımış olması, gerçek aşkın insana duyulan aşkın ötesinde bir aşkın varlığına yapılan atıftır. Şair, önce sevmek, âşık olmak vardı, sonra bu duygu bir insan için kullanıldı; anlamını hatırlatır. Buna göre de mutlak aşk, Allah aşkıdır. Namık Kemal aynı anlama gam ve keder üzerinden yaklaşır:

Mihnetim mahvetti dehri dilde peydâ gam henüz

Gam bitirdi âlemi bitmez Gam-1 âlem henüz

(Gönülde gam henüz yeni başlamışken derdim dünyayı mahvetti. Gam âlemi bitirdi ancak âlemin gamı henüz bitmez.)

Gamdan önce dert vardır. Dert çekilir ve bu süreçte gam ve keder de arkasından gelir. Ama çekilen dert öyle büyüktür ki henüz ona üzülmeye zaman gelmeden gam, keder dünyayı mahveder. İnsanları gam bitirir, ancak yine de insanların gam ve kederi bitmez. Nabi'nin gazelinde aşk ve âşı arasında yapılan paradoks Namık Kemal'de dert ve gam arasında yapılır.

17.yy. şairlerinden hiciv ustası olarak bilinen Nef'i gerek pürüzsüz dili, zengin bir ahenk ve musikisi ile Namık Kemal'in dikkatini çeker. Divan şairlerinin birçoğunun kaleme aldığı "bana" redifli gazelinde;

Şâh-1 aşkım âlem-i ma'na müsellemdir bana

Ser nigûn peymâne-i Cem tâc-1 Edhemdir bana tâcidir.)

(Aşk şâhıyım ki ma'na âlemi bana teslimdir. Cem'in kadehi bana baştan aşağı Edhem'in

İbrahim bin Edhem divan edebiyatında dünya nimetlerinden vazgeçerek zühd yolunu seçmesi ile destanlaşan bir isimdir (Öngören, 2000: 293). Peymâne-i Cem (Câm-1 Cem) de "içine bakıldığı zaman dünyada olup biten her şeyin görüldüğüne inanılan kadeh" (Yazıc1, 1993: 42) tasavvufta ise her türlü kötülükten arınmış tertemiz gönül” anlamında kullanılır. Nef'i tarihî şahsiyetleri anıştırarak güçlü bir anlam çerçevesi oluşturur. Aşk şahı olan şair, mana âlemlerinin de sahibidir. Bu nedenle her türlü kötülükten arınmış gönlü, ona dünyadan geçen ve gerçek aşka ulaşan Edhem'in tacı gibidir. Gerçek aşka ulaşıldığında geçici aşkların önemi kalmaz. Bu şiir, maddeden manaya geçişin bir özeti olarak da okunabilir. Namık Kemal, Nef'i'nin aşk konusunda ulaştığı mertebeye gam ve keder ile yaklaşır. Tur dağında Hz. Musa ile Allah'ın ayrılışı, Kerbela'daki ayrılış1 hatırlatan şair, üzüntüsünü bu şekilde dile getirir:

Hecr ile Tûr-i tecellâ bezm-i mâtedir bana

Her münevver berkı bir mâh-1 muharremdir bana 
Müntehâ vü mebdeinde görmedim nûr-i visal

Devre-i âlem serâpâ devre-i gamdır bana (sy. 261)

Divan şiirinin en sık kullanılan mazmunlarından olan felek, Nef'i'nin şiirlerinde de belli başlı şikâyet edilen unsurlardandır:

Sanman ki felek devr ile şâmı seher eyler

Her vakıanın âkıbetinden haber eyler

(Felek devrederek akşamı sabah eder zannetmeyin. Felek her olayın sonundan haber verir.)

Dünyanın dönmesi sadece gece ile gündüz arasındaki devranı sağlamaktan öte, yaşanan olayların sonunu gösterir. Nef'i, dünyanın doğal akışına bir başka noktadan bakar. Geçmiş, an ve gelecek arasındaki döngü, dünyanın asıl görevidir. Bu beyit sade bir söyleyiş ve ahenge sahiptir. "Felek - devr" ve "vâkıa - âkıbet" kelimeleri arasında bir ahenk oluşur. Her iki mısranın ilk kısmında geçen bu kelimelerdeki sertlik ikinci kısmında ve redifle birlikte kolay bir söyleyişle yumuşar. Şiir kalın ve ince sesler arasında oluşturulan iki perde arasında akar. Namık Kemal'in özellikle bu şiire nazire yazdığını söyleyebiliriz. Şiirdeki bu musiki renkliliği Namık Kemal'in şiirde aradığı ahenktir:

Çeşmin ki ne dem hışm ile atf-ı nazar eyler

Bir nazresi bin kişveri zîr ü zeber eyler (sy. 374)

İlk mısrada üçlü perde, ikinci mısrada ise iki perde kullanan Namık Kemal, anlam ile ses değerlerini eşleştirir. "Hışm” ile birlikte kalın ünlüleri kullanan şair, "nazre" ile yumuşayan anlamı ince sesler ile destekler. Bu şiir, Namık Kemal'in musiki unsurları ile de incelenebilecek bir şiirdir.

Nef'i'nin;

İhyâ eden endişeyi feyz-i nefesimdir

Endişe benim tıfl-i dil-i nev hevesimdir

matlalı gazeli de Namık Kemal'in hem söyleyiş hem de anlam olarak tanzir ettiği bir gazeldir. Nef'i endişeyi bir yaşam tarzı olarak ifade eder. Endişeyi alıp verilen her nefesle canlı tuttuğunu belirten şair gönlünün bu endişeyi besleyip koruyup kolladığını ifade ediyor. Emniyet ve endişe insan hayatının iki önemli halidir. Bu ikisi arasında gidip gelen insan hayatını daha sağlıklı devam ettirebilir. Bu nedenle de endişenin nefesle bağlanması anlaşılabilir bir yaklaşımdır. Namık Kemal ise;

Bir bülbül-i Tûr'um dil-i Mûsî kafesimdir

Siyt-1 Erinî nâle-i âteş nefesimdir (sy. 384)

matlalı şiirinde Hz. Musa'nın Tur Dağı'nda Allah ile konuşmasına atıf yapar. Hz. Musa'nın Tur Dağı'nda Allah ile konuşması divan şiirinde sıklıkla işlenen bir konudur. İnsanın ulaşması istenilen son nokta Allah'la konuşmasıdır. İnsanlar için ancak cennette gerçekleşecek bu görüşme, tasavvuf anlayışında dünyada bir hedef olarak gösterilir. Nef'i'nin şiirinde insanın iki halinden biri olan endişe üzerinde durulurken Namık Kemal insanın kemal noktasına işaret eder.

Nef'i'nin "nevruz" redifli şiiri klasik anlayışa uygun olarak geleneği devam ettiren bir gazeldir. Baharın başlangıcı olarak kabul edilen nevruz, bir başlangıç olması ve beklenen, arzu edilen bir zaman olması bakımından işlenir. Nevruz ile birlikte "cam-1 Cem" de kullanılan bir mazmundur. "İçine bakıldığı zaman dünyada olup biten her şeyin görüldüğüne inanılan" (Yazıcı, 1993: 42) cam1 Cem, nevruzun gelmesi ile birlikte insanları mutlu eden, huzura kavuşturan bir nesnedir. Namık Kemal, nevruza Nef'i de olduğu gibi olumlu değil olumsuz anlamda yer verir: 


\section{Bir tıfl-1 yetîm-i elemiz etmeyiz ikbâl}

Bin îd-i sürur olsa eğer tev'em-i nevruz (sy. 430)

Şair için keder, elem o kadar içe işlemiştir ki nevruz ve bayram sevinci birlikte gelse bile bir mutluluk beklemek hayaldir. Namık Kemal, hüzün, keder üzerinde daha önceki şiirlerde de tespit ettiğimiz gibi daha fazla durur. Bunda devrin genel havası, sosyal ve siyasi şartlarının etkili olduğunu söylemek mümkündür. Nevruz'un genelde neşe kaynağı olarak görülmesine rağmen Namık Kemal, nevruzun bile elemi gidermediği ve mutluluk getirmediği üzerinde durur. Bu devrin anlayışının şairin şiirine yansıması olarak görülebilir.

Abdülbâki Vecdî 17. Yy. şairleri arasında ismi geçen ancak üzerinde çok durulmayan bir şairdir. Bilinen tek eseri olan 550 beyitlik Divan'ının farklı kütüphanelerde kırka yakın nüshasının bulunması şairin okunan ve beğenilen bir şair olduğunu göstermektedir (Yekbaş, http://www. turkedebiyatiisimlersozlugu.com). Vecdî’ye kendi devrinden itibaren birçok şair nazire yazar. Şairin şiirlerinde daha çok aşk, rindlik ve ıstırap duygularına ağırlık vermesi Namık Kemal'in de ilgisini çeker ve şairin dört şiirine nazire yazar.

Naili, Leskofçalı Galib Bey ve Hersekli Arif Hikmet gibi birçok şairin de nazire yazdığı "peydâ" redifli gazele Namık Kemal de nazire yazar. Özellikle devrin diğer şairleri tarafından yazılan nazireler konusunda Namık Kemal de geri durmaz. Özellikle Leskofçalı Galib Bey ve Hersekli Arif Hikmet'in nazire yazdığı şairlere o da nazire yazar. Vecdî’nin "peydâ" redifli gazeli de bunlardan biridir.

Gam-1 zülfünle âhımdan k'olur dûd-i derun peydâ

Eder destâr-1 sünbül-i bâğ-1 cünun peydâ

Sevgilinin saçı, divan edebiyatında sevgilinin güzellik unsurları içerisinde en zengin olanıdır. Renk, koku ve şekli ile şiirlere konu olan saç, aynı zamanda âşığa hüzün vermesi bakımından da ele alınır. Bu beyitte de benzer bir durum söz konusudur. Sevgilinin zülfünün verdiği hüzün aşığın içinden gelen duman ile ortaya çıkar. Ortaya çıkan duman âşık bağının sümbülünün sarı̆̆ı olarak görünür. Şair sevgilinin saçlarının bukle şeklinde oluşunu sarığa benzeterek zengin bir teşbih oluşturur. Namık Kemal yazdığı gazelde saçın kokusu üzerinde durur:

Edince zülf-i sevdâ perverin bûy-i füsun peydâ

Dimă̆-1 akl-1 f'aâl eyler âsâr-1 cünun peydâ (sy. 253)

Sevgilinin saçının kokusu ortaya çıkınca akıl çalışır ve aşığın eserleri görünmeye başlar. Vecdi'nin saçın şekli ile kurduğu hayal Namık Kemal de saçın kokusu ile yapılır. Sevgilinin saçının kokusu aşı ̆̆ kendine getiren varlığını ispatlayan bir araçtır.

Vecdî’nin diğer şiiri "etse de" redifli aşk ve ıstırap duygularının yoğun olarak işlendiği gazeldir:

Kâsdı cân almaktır ol zâlim eğer dâd etse de

Şâd merk etmek murâd eyler yine sâd etse de

(O zâlim adalet etse de asıl amacı can almaktır. Paramparça etse de aslında mutluluk vermeyi amaçlar.) Tezat sanatı ile oluşturulan beyitte, aşkın iki hâli gösterilir. Sevgili âş̧k için hem bir mutluluk hem de üzüntü kaynağıdır. Hüznün olmadığı yerde gerçek aşktan da bahsedilemez. Bu nedenle divan şairleri aşk acısından memnundurlar. Namık Kemal de tanzir ettiği şiirde aynı anlamı farklı kelimelerle ifade eder. Sevgili âşığı âlemin üzüntüsünden azat etse de bunu ancak ölümle yapar. Amaç güzel bir şey olsa da sevgili acının daha fazlası ile çözüm bulur. Vecdi'nin şiirinden söyleyiş olarak oldukça sade ve bir tekrardan ibaret olan şiirin tüm mısralarında kuru bir söyleyiş hâkimdir. 
Bâde kim dâğ-1 dil-i endişedir her katresi

Âfet-i akl-1 Felâtun pîşedir her katresi

matlalı gazelde aşk, bâdeye içkiye benzetilir. Şair, bâdenin her katresini endişeli gönlün yarasına ve Eflatun'un aklının güzelliğine benzetir. Bu beyit de aşkın aklı harekete geçirdiği şaire hayat verdiği üzerinde durulur. Vecdî şiirlerinde aşk ve akıl kavramlarını birbiri ile bağlantılı kullanır. Onun için aşk hem gönül hem de akıl işidir. Namık Kemal'in naziresinde ise bu bağ üzerinde durmaz. Bir önceki şiirde de olduğu gibi Namık Kemal'in gerek söyleyiş gerek anlam bakımından başarısız şiirlerinden biri de bu şiirdir. Şiir yapılan benzetme ve hayal olarak Vecdî’nin oldukça altında kalır:

Bâde kim minâ füruz-1 şişedir her katresi

Mey değil hurşî̀-i âteş pîşedir her katresi (sy. 318)

Vecdî’nin “göster” redifli gazeli 17. yy.'ın birçok şairi tarafindan çok beğenilerek nazire yazilır;

Lâ'lin tebessüm eyle pür âb ü tâb göster

Yâkut-i sürh içinde dürr-i hoşâb göster göster.)

(Tebessüm ederek güzelliğini göster. Kırmızı yakut içinde inci gibi güzelliğini, parlaklığını

Sevgilinin güzelliğinin inci, yakut gibi kıymetli, az bulunur nesnelerle anlatılması ona karş1 duyulan aşkın ve arzunun bir göstergesidir. Sevgilinin tebessüm etmesi, aşığın en büyük hayalidir ve âşık için çok değerlidir. Bu nedenle sevgilinin küçük bir ilgisi, bir tebessümü yakut, inci gibi ifadelerle birlikte kullanılır. Namık Kemal gazelinde benzer ifadelerle bu anlamı tekrar eder. Bu anlamda Namık Kemal'in özgün bir söyleyişinin olduğunu söylemek zordur:

Rûyinde lâ'l-i nâbın pür âb ü tâb göster

Bezm-i behişt-i hüsne câm-1 şerâb göster (sy. 375)

(Yüzünde dudağının saf parlaklığını göster. Güzellik cennetinin şarap şişesini göster.) Sevgilinin dudağının güzelliği ve parlaklığı her iki şairde de ortaktır. Vecdî, yakut ve inci gibi değerli nesnelerle birlikte dudağın kıymetinden bahsederken, Namık Kemal bu hayali cennet şarabına benzetir. Bu gazelde şairin kendi şiir anlayışından oldukça farklı bir benzetme yaptığı görülüyor.

17. yy. şairlerinden Bahayî, Danişi Ali Dede ve Diyarbakırlı Hâmi gibi şairler de şiirleriyle 19.yy. şairlerinin ilgisini çekmiş ve şiirlerine nazireler yazılmıştır. Bahayî̀nin şiirlerinde az sözle çok şey söyleme, hayal dolgunluğu, titiz misra işçiliği (Uludağ 2013, http://www.turkedebiyatiisimlersozlugu.com); Danişi Ali Dede'nin ahenkli şiirleri, Diyarbakırlı Hâmi'nin mahalli söyleyişi Namık Kemal'in de şiir kaynakları arasında yer alır.

Bahayi'nin;

Îtâb-1 la'l-i nâbından gönül pür pîç ü tâb olmaz

Bilir kim kân-1 âteşten çıkan hançerde âb olmaz

matlalı şiirinde "sevgiliden gelecek her türlü cefaya razı olma" anlayışını sürdürür. Nasıl ki ateşin kaynağından çıkan hançerde su olmazsa sevgilinin tüm azarlarından da gönül rahatsız olmaz. Namık Kemal yapı itibariyle gazeli tanzir eder:

Fürug-i mihr-i âlem sûz-i aşka dil hicâb olmaz

Değil bir kabza hâk ol âteşe dağlarda tâb olmaz (sy. 413) 
Sevgilinin âşığa olan ilgisi karşısında âşığa hiçbir şey engel olmaz. Bir avuç toprak değil dağlar bile o ateşe engel olamaz. Aşk ateşinin gücünü anlatan her iki beyit de güçlü bir teşbih sanat1 söz konusudur. Bahayi'nin diğer beytinde de yine benzer bir anlam ve üslup söz konusudur:

Âşık neşât-i meclis-i ayş ü dem istemez

Hûn-i dilin koyup mey-i câm-1 Cem istemez

Âşı̆̆ın tek isteği sevgiliye duyduğu aşkın devam etmesidir. Âşı̆̆ı ayakta tutan, hayata bağlayan da bu aşktır. Âşığın aşkını da sürekli hâle getiren aşk acısıdır. İçki meclislerinin verdiği mutluluk, içki kadehleri de âşığın istediği bir hal değildir. Âşık gönlündeki kanayan yarayı, aşk acısının devamını ister. Bu iki beyit de klasik anlayışın bir ifadesidir. Ancak Bahayi'nin şiirlerinde Tasavvufî yoruma açık bir kullanım yoktur. Bahayi şiirlerinde beşerî aşkı işler. Namık Kemal de Bahayi'nin gazellerini tanzir ettiği şiirlerinde beşerî aşkı konu edinir. Aşk acısı ile yaşamayı tercih eden âşık her iki şairde de benzer şekilde ifade edilir:

Sinemde dâg-1 şu'lefeşan merhem istemez

Gülberg-i bâg-1 Tûr eser-i şebnem istemez (sy. 41)

Namık Kemal birçok şiirinde Hz. Musa'nın Tur Dağı hadisesine gönderme yapar. Burada da Tur Dă̆ı'nı kullanması teşbihi güçlü hale getirir. Hz. Musa'nın Allah'la dünyada konuşması bir insan için ulaşılabilecek son noktadır. Namık Kemal'in özellikle bu noktayı şiirlerinde sıklıkla işaret etmesi ve özgün benzetmeler oluşturması, tanzir ettiği şiirdeki anlam ve yapıyı tekrar ederken kendi üslubunu ortaya çıkaran bir göstergedir. İkinci mısrada Tur Dağı bağlarındaki gül yaprakları nasıl çiğ istemezse, bu onlara zarar verirse, aşk acısı ile kemale eren ve aşkta son noktaya ulaşan âşık için onun acısını dindirecek hiçbir şey istemez.

Dönemin Mevlevi şairlerinden olan Danişi Ali Dede ise şiirlerinde ahenk unsurlarını ön plana çıkartır. Namık Kemal'in ilgisini bu ahenk çekmiş olmalıdır:

Bezm-i aşkından senin meyhâne bir ben bir habâb

Baş açık yalın ayak dîvâne bir ben bir habâb

Sıfatların isimlerden sonra kullanıldığı gazelde ince sesliden kalın sesliye doğru bir akış söz konusudur. İsim ve sıfatın başta vurgulu olarak ifade edilmesinden sonra bu yumuşak geçiş şiir üslubuna bir hüzün katar. Namık Kemal'in şiiri de aynı yapı ve ahenk üzerine kuruludur:

Sâil-i tih cür'a-i meyhâne bir ben bir habâb

Nazrasenc-i hasret-i peymâne bir ben bir habâb (sy. 277)

Namık Kemal'in 17. yy. şairlerinden nazire yazdığı son şair, şiirlerinde mahalli söyleyişe önem veren Diyarbakırlı Hami'dir:

Dil yine pür şerha-i âlâm mânend-i nigîn

Muttasil tutsam elimde câm mânend-i nigîn

Şair, elem ve kedere farklı bir açıdan bakar. Gönüldeki elemlerin her parçası bir mühür gibidir. Sevgilinin aşığa verdiği elem bir mühür gibi gönle işlenmiş ve sürekli onu hatırlatmaktadır. $\mathrm{Bu}$ nedenle de şairin sevgilinin mührü olarak görülen gönül yaralarından kurtulmak gibi bir düşüncesi yoktur. Namık Kemal de şiirinde;

Rû siyehlikle verirmiş nâm mânend-i nigîn

Olma dest âmûz-i hâs u âm mânend-i nigîn (sy. 358) 
mısralarında toplumsal bir durumu vurgular. Siyaha boyanmış yüz, herkesin tanıyacağı, bileceği bir mühür gibidir. Bu şekilde herkes tarafından tanınmaktan kaçınılması düşüncesini ifade eden şair, şiirin tamamında toplumsal mesajlar verir.

\section{3) 18.yy. Şairlerine Yazılan Nazireler}

Encümen-i Şuara şairleri, divan şiirini canlandırmak ve eski güçlü günlerine geri döndürebilmek amaciyla özellikle 16. ve 17.yy. şairlerini örnek almayı tercih ederler. Divan şiirinin güçlü şairleri bu yüz yıllarda yetişmiştir. 18.yy. ise divan şiiri açısından duraklama ve gerileme dönemidir. Bu dönemde yetişen şairler yeni bir şeyler ortaya koyamaz ve daha çok eskinin tekrarı ile yetinirler. Bu nedenle de encümen-i şuara şairleri 18. yy. şairlerinden sadece Nedim'i özgün bulurlar ve onun şiirlerine nazireler yazarlar. Nedim de şiirlerinde ses ve ahenk unsurlarına önem veren, musiki gibi şiir yazan bir şairdir. Encümen-i şuara şairlerinden Galip Bey, 17.yy.dan itibaren aslî maksadını kaybeden tanzir geleneğine, halkanın koptuğu yerden kendi neslini eklemek çabasındadır. (Özgül, 2015: 32) Namık Kemal de diğer encümen şairleri gibi Nedim'in bu özelliğinden yararlanır. Ancak Namık Kemal'in okuma listesinde Nedim'in de yer almasına rağmen şair, onun sadece bir şiirine nazire yazar.

Nedim'in;

Nâz olur dembeste çeşm-i nîm hâbından senin

Şerm eder reng-i tebessüm la'l-i nâbından senin

"sevgilinin yarı uykulu gözleri nazın soluğunu keserken gülümsemesinin rengi de dudağının halis lâlinden utanır" ifadelerine yer verilir. Sevgilinin gözü ve dudağı divan şiirinde sıklıkla kullanılan mazmunlardır. Nedim, şiirlerinde beşerî aşkı işlediği için tasvirleri de beşeri güzellikler üzerinedir. Sevgilinin gözleri ve nefes arasında, gülümsemesi ile de dudağın rengi arasında zengin bir çağrışım kurar. Namık Kemal ise;

Can bulur şahs-1 ecel lûtf $\mathrm{u}$ hitabından senin

Havf eder tiğ-i kazâ cevr ü itabından senin (sy. 435)

mısralarında Nedim'in kurduğu hayalin zıddını oluşturur. Sevgilinin hitabı ile ecel bile can bulur, kaza okları da senin zulmünden azarlamandan korkar. Sevgili, varlığı ile kendi dışındaki her şeye yön veren bir özelliktedir. Ecelin can bulması, kazanın korkması Namık Kemal'in özgün söyleyişleri arasindadir.

\section{4) 19.yy. Şairlerine Yazılan Nazireler}

Encümen şairleri önceki yüz yıllardaki şairlere nazire yazarken bir yandan da encümendeki diğer şairlerin şiirlerini de tanzir ederler. Özellikle genç şairlerin kişilik bulma ve ustalaşma gayretleri bu geleneğin oluşmasında önemli bir etkendir. Şairler, birbirlerinin şiirlerine de nazireler yazarak aynı zamanda nazire yazılan şairin de ustalığını kabul etmiş olurlar. Encümen şairleri arasında Namık Kemal'in ifadesi ile "muktedâ-yı irfan” (Özgül 2014; 41) olarak bildiği iki isim Leskofçalı Galib Bey ve Hersekli Ârif Hikmet Bey şiirlerine en çok nazire yazılan isimlerdir. Her iki şair de gerek düşünceleri gerekse şiir anlayışları ile genç şairler üzerinde etkili olurlar. Namık Kemal çağdaşı olan şairlerden Leskofçalı Galip Bey'in 52, Hersekli Arif Hikmet Bey'in 32, Fehim'in 17, Osman Şems'in 15, Halet Bey'in 5, Arpaeminizade Sâmi'nin 7, Şem'i'nin 1, Selim'in 1, Faik-i Memduh'un 2, Şinasi'nin 1, Akif Paşa'nın 1şiirine nazire yazar.

Leskofçalı Galip Bey'in Namık Kemal'in şiir anlayışında ayrı bir yeri vardır. Çok küçük yaşlardan beri aralarında devam eden ilişki önce ağabey-kardeş daha sonra ise usta çırak ilişkisi olarak devam eder. Selanikli Fâik Paşa ve şairin kızı Ayşe Hanım'ın damadı olan Mehmed Galib Bey'in İbnülemin'e Leskofçalı Galib Bey'in kekeme olduğunu ifade etmeleri, onun edebiyat 
anlayışının diğer şairlere aktarılabilmesi için yardımcıya ihtiyaç duyma nedenini açıklar. Güzel ve etkili konuşması ile herkesi kendine hayran bırakan Hersekli Ârif Hikmet Bey ve güzel şiir okuyan Namık Kemal şairin en büyük yardımcılarıdır (Özgül, 2015: 26). Her iki şair de Leskofçalı Galib Bey'den oldukça etkilenirler. Namık Kemal'in Hürriyet Kasidesi'nin çıkışının da şair olduğu göz önüne alınınca şairin etkisi daha iyi anlaşılmaktadır. Ahmet Hamdi Tanpınar'ın şairden bahsederken "Onun şiirinde, eskilerin zevk düşüklüklerine pek az rastlanır" demesi Namık Kemal'in edebi dil kriterleri incelendiğinde iki şair arasındaki bağı açıklar. Namık Kemal, Harâbât'ın "mukaddimesi”ni tenkid ederken Leskofçalı Galib Bey'in dil üzerindeki görüşlerini esas alır.

Leskofçalı Galip, klasik şiirdeki biçim unsurlarında bazı değişikliklere gitse de bu konuda onu ilk olarak kabul etmek hatalıdır. Kaside olarak yazdığg şiirde "tegazzül" bölümü haricinde kasideye benzeyen bir yapı göstermez. Şairin bu değişiklikleri bir ilk olarak kabul edilmese de daha sonra batılı formların edebiyatımıza girişinde ve yeni arayışların temelindeki zihniyeti ve pratiği göstermesi bakımından önemlidir. Şiirlerinde klasik şiirin birikimi olan aşk, tasavvuf, tefekkür gibi konuların dışına pek çıkmayan şairin asıl yeniliği eski muhtevayı ele alış biçimidir. (Özgül, 2015: 33) Yine Galib'in vecize ve atasözünü hatırlatacak mısralar söylemesi de bu yenilikler arasında sayılabilir. Bu özellik Şinasi ve Namık Kemal'de de görülür.

Dil ve ifade zenginliği, hayal gücünün genişliği, imge ve simgenin çarpıcıllğ 1 , estetik güzellik esasları üzerine kurduğu şiirlerinde zaman zaman sosyal muhtevalara da yönelir. Dünyayı ilâhî güzelliğin tecelli yeri olarak gören şair özellikle ilâhî güzelliğin en fevkalâde tecellisi olan $\mathrm{Hz}$. Mûsâ'nın Allah'la konuşmasına dair mazmunları sıkça kullanır. Bu anlayış Namık Kemal'de de aynı şekilde devam eder. Onun, mutasavvıf şairlerden farkı ferdiyetçiliği tercih etmesidir. Ancak ferdiyetçiliği tercih eden şairlerden de şiirlerinde "ben" derken "biz"i düşündürmesidir. (Özgül, 2015: 36)

Leskofçalı Galib Bey, gerek şiir anlayışı ile gerekse encümen şairlerine iyi bir örnek oluşu ile devrinde üstad olarak kabul edilir. Onun yanı başından ayrılmayan Namık Kemal, şiir anlayışını bu sağlam temeller üzerine kurar. Şiirleri ve şiir anlayışı ile yeniliğin alt yapısının oluşmasında önemli bir yere sahip olan şairin şiirleri başta Namık Kemal olmak üzere diğer encümen şairlerince tanzir edilir. Namık Kemal'in tanzir ettiği şiirler arasında ağılık Leskofçalı Galib Bey'in şiirlerindedir. Namık Kemal'in sadece şairin şiirlerini tanzir ettiği şiirlerinde değil diğer şiirlerinde de Galib Bey'in etkisini görmek mümkündür. Galib Bey'in şiirlerinin Namık Kemal'e etkisi, benzerlikleri ve farklılıkları ayrı bir araştırma konusudur. Bu konuda yapılacak çalışma iki şair arasındaki usta çırak ilişkisinin daha iyi anlaşılmasına katkı sağlayacaktır. Bu çalışmada ise sadece Namık Kemal'in tanzir ettiği şiirler incelenmekle yetinilecektir.

Namık Kemal'in Leskofçalı Galip Bey'in ilk tanzir ettiği şiiri, Naili, Vecdi ve Hersekli Arif Hikmet'inde benzer şiirleri olan "peydâ" redifli şiirdir:

Tenim pür dağdır yekser dil-i âgâh nâpeydâ

Cihan bâğ1 selâm olmuş Hâllullah nâpeydâ (Leskofçal1, sy.5)

(Tenim baştan ayağa yarayla doludur; ama uyanık gönül ortada yok. Cihan -Hz. İbrahim'in atıldığı, daha soğuk ve selamet olan ateşten- selam bahçesine dönmüş; ancak Hz. İbrahim ortada yok.)

Şair iki zıt durum üzerinde duruyor. Tenin yaralar içinde olmasına rağmen, gönül bundan habersizdir, Hz. İbrahim'in atıldığı ateş selam bahçesine dönmüş ancak Hz. İbrahim ortada yok. Çekilen çile, acı, ızdırap devam etmesine rağmen bir şeyler eksiktir. Zaman her şeyi değiştirmiş; fakat eksik bir şeyler bırakmıştır. Gönül artık acıları bile hissetmeyecek kadar hissizleşmiş ve ilgisini kesmiştir. Namık Kemal'in şiirinde "pür dağ" ifadesi daha açık hale getirilir. Galib Bey'in vücudun İlahî aşka ulaşamamanın verdiği izlerle yaralı olduğu benzetmesi Namık Kemal'de yerini doğrudan 
“gark-1 tecellâ" mekânına dönüşür. Ancak vücut Allah'ın tecelli mekânı olmasına rağmen gönül bundan habersizdir. Bu tecelli her taraftan görülebilmesine rağmen tek eksik Allah'ın kelamının olmayışıdır. Galip Bey'in divan şiiri mazmunlarını kullanarak bu mazmunları zamana uyarlaması Namık Kemal tarafından da taklit edilir. Galip Bey'in divan şiiri mazmunlarını kullanmaktaki başarısı Namık Kemal'in nazirelerinde de görülmektedir.

Olup mürsâyi hikmetten serefrâz-1 yemm-i ma'na

Açıldı keşt-i endişe Bismillahi mecraha. (Leskofçalı, gazel 1) adıyladır.)

(Fikir gemisi, hikmet limanından demir alıp mana denizine açıld1- 'Onun yüzüşü Allah'ın

Hz. Nuh'un gemisinin tufan içerisinde sakin bir şekilde yol aldığını anlatan âyete telmihte bulunan Galip Bey, bu mazmunu fikir ile bağdaştırır. Fikir gemisi, hikmet limanından demir alarak mana denizine yol alır. Tasavvufî bir anlam içeren şiirde, fikir ve hikmet bir bütün olarak görülür. Galip Bey'in bu şiirlerinde divan şiirinin karakteristik özelliklerini görmek mümkündür. Galip Bey'in divan şiirine bakışı ve mazmunları güncelleyerek zamana uygun kullanması, başta Namık Kemal olmak üzere diğer encümen şairleri için de örnek teşkil eder. Namık Kemal bu şiire yazdığı nazirede;

Edüp fülk-i cihanpeymâ-yı dil azm-i yem-i ma'na

Açıldı bâdbân-1 aşk Bismillahi mecraha (sy. 266)

Galip Bey’i anlam olarak da takip eder. Aşk yelkeni, mana denizinde dünyayı dolaşma gayretindedir. Aşkın bu şekilde ele alınması, özellikle de Nuh'un gemisi ile bağdaştırılması yeni bir kullanım olarak görülmektedir. Karmaşa içindeki sakinlik aşkı yeniden tarif etmektedir.

"İstiğna” redifli gazelde Galip Bey, "yüce gönüllülük (hiçbir şeye ihtiyaç duymama)" üzerinde durur. Her şeyden el çekme, hiçbir şeye ihtiyaç duymama olarak tanımlanan istiğna, tasavvufun insanı ulaştırmak istediği merhalelerden en önemlisidir. Galib Bey'in;

Dile iklim-i Cem'dir gülşen-i me'vâ-yi istiğnâ

Murassa' tâc-1 zerdir gonce-i zîbâ-yi istiğnâ (Leskofçalı, gazel 3)

mısraları ile başlayan gazeli, Namık Kemal'de benzer şekilde kurgulanarak "istiğna" olarak farklı örneklendirmeler yapılır. Mısraların kuruluşu ve söyleyiş benzerliği iki şair arasındaki kuvvetli ilişkinin görülmesi bakımından önemlidir.

“âftâb” redifli gazelde Galib Bey, Hz. Musa'nın Tur Dağı'nda Allah ile konuşması hadisesine telmihte bulunur. Gerek Galip Bey'de gerekse Namık Kemal'de Tur Dağı hadisesi önemli bir yere sahiptir. Birçok şiirde bu hadiseyi farklı şekillerde dile getirirler.

Mihr-i rûyin olsa şevk efrûz-i sûy-i âftâb

Bir çerâğ-1 Tûr olur her gerd-i kûy-i âftâb (Leskofçalı, sy. 260) (g.17-1)

(Yüzünün sevgisi güneş gibi şevkimi tutuştursa, güneşin eşiğinin her tozu bir Tur (Dağı) meşalesi olur.)

Sevgilinin yüzü âşığı her zaman cezbeder. Aşk, arzu sevgilinin yüzünde belirginleşir. Tasavvufî olarak da Allah'ın "Cemal" sıfatının tecelli ettiği yerdir. Galib Bey de bu anlamı vurgular. Sevgilinin yüzünün ışığı âşık için Allah'ın Tur Dağı'nda Hz. Musa ile konuşması, orada tecelli etmesi gibidir. Âşık için sevgili ile buluşma anı, sevgilinin âşığa ilgi gösterdiği andır. Namık Kemal tanzir ettiği şiirde ise; 
Şem-i hüsnün olsa feyzefzâ-yı sû-yi âftâb

Fer verir mişkât-1 arşa reng-i rûy-i âftâb (sy. 279)

Sevgilinin güzelliğinin 1şığının güneş gibi bütün dünyaya 1şık verdiğini söyler. Bu şiirde kullanılan mazmunlar bakımından Namık Kemal daha başarısızdır. Anlamı tekrar ederken özgün bir benzetme kullanmaz.

Derd-i firâk perde der-i hâbdır bu şeb

Gönlüm diriğ haste-i bîtâbdır bu şeb (sy. 281) (g.19-1)

Misralarıyla başlayan "şeb" redifli gazelde Galip Bey "ayrılık" derdini konu edinir. Sevgiliden ayrılık divan şiirinin de değişmez bir bakış açısıdır. Gece ile birlikte âşığın aklına sevgiliden ayrılık gelir. Gönlün hastalığının da tek sebebi bu ayrılıktır. Namık Kemal şiirinde:

Diller ki cûş-i şevk ile şâdâbdır bu şeb

Her mevc-i nâle hâle-i mehtâbdır bu şeb (sy. 281)

(Gönül, bu gece şevk coşkusu ile doludur. Her ağlama dalgası mehtâbın bir halesidir.)

Ayrılıktan çok ayrılığın sonucu üzerinde durur. Ağlama, şairin ayrılıktan duyduğu hüznün bir yansımasıdır. Bu şiirde Namık Kemal diğer şiirlerden farklı olarak Galib Bey'in kapalı bıraktı̆̆ı alanları açmak yerine Galip Bey'de açıkça söylenen bir durumu daha kapalı bir anlatımla ifade eder.

"Tecrid" redifli şiirde Galib Bey, "gönül kartalının felekte tecrid alemini dolaşmaya başladığında kanadının sesinin Mesih'e tecrid rahberi olur" der. Tecrid, her şeyden soyutlanma, arınma anlamındadır. Hz. İsa'nın da dünyadan öbür âleme alınması, bir tecriddir. Kendisine kötülük yapmak isteyen insanlardan Allah onu korur. Tasavvufta yine bir makam olarak görülen tecrid ise âşığın dünyaya ait her şeyi bırakması anlamında kullanılır. Bu şiiri anlam olarak "istiğna" redifli şiirle birlikte ele almak mümkündür. Namık Kemal aynı redifli şiirinde Hz. İsa yerine Hz. Cebrail'i kullanır. Aynı anlamı vurgulayan şair, Galib Bey'in şiirinden farklı bir anlam dünyası oluşturmaz:

Olunca mürg-i himmet arşta cevlânger-i tecrîd

Eder Cibril'i sergerdan sadâ-yi şehper-i tecrîd (sy. 289)

Galib Bey "kalp ile" redifli gazelinde aşk ve güzellik üzerinde durur:

Hüsn ü aşkı cem'ü kalb ettik meâl-i kalb ile

Vâkıf-1 sırr-1 kazâyız biz kemâl-i kalb ile (sy. 296) (g.109-1)

(Biz) kalbin manasıyla güzellik ve aşkı birleştirip (birbirine) dönüştürdük; biz kalbin olgunluğuyla kader sırrının vakıfıyız.)

Güzellik ve aşkın kalpte birleşerek dönüşmesi kalbin olgunluğunun işaretidir. Kalbin olgunluğu da kader sırlarının anlaşılması için bir merhaledir. Galib Bey'in bu gazeli klasik divan şiiri kalıplarının dışında yeni bir biçim denemesidir. Divan şiirinde edat ile biten şiirlere çok sık rastlanmaz. Bu yeni biçim denemesini Namık Kemal'de takip eder:

Şerh ü tafsil-i kazâ birdir meâl-i kalb ile

Ma'ni-i Ümmülkitâbız biz kemal-i kalb ile (sy. 296)

Namık Kemal, Galib Bey'in şiirlerini tanzir ederken şiirini sebep sonuç ilişkisi içerisinde adeta Galib Bey'in şiirini anlam olarak tamamlamak ister. Kullanılan mazmunlar, Galib Bey'in şiiri ile karşılaştırıldığında bir bütünün parçaları gibidir. 

bulunur:

"Üstüne" redifli gazelde de Galib Bey yine Hz. Musa ve Tur Dağı hadisesine telmihte

Aks-i merdum kim düşer ol rûy-i pür nûr üstüne

Rûh-i Mûsâ'dır çıkar sad şevk ile Tûr üstüne (sy. 298) (g.108-1)

(Gözbebeğinin yansısı o 1şık dolu yüzün üzerine düşer. Musa'nın ruhu yüzlerce coşkuyla Tur dağının üzerine çıkar.)

Gözbebeği, Allah'ın tecelli ettiği yer olarak kullanılan bir mazmundur. Onun yüze yansıması Tur Dağı'nda Hz. Musa'nın Allah'la konuşması gibi etki meydana getirir. Galib Bey'in, Hz. Musa ve Tur Dağı hadisesini farklı şekillerde şiirlerinde kullandığını belirtmiştik. Burada da aynı hadiseyi, Allah'ın her insanda tecelli ettiği nokta üzerinden yineler. Namık Kemal, daha önceki gazellerde olduğu gibi bu gazele yazdığg tanzirinde Galib Bey'in şiirini tamamlar:

Dâğlar açmış cemâlin cism-i rencûr üstüne

Tarh-1 gülzâr eylemiş Hak nurdan Tûr üstüne (sy. 298)

Allah'ın cemalinin hasta vücuda tecelli etmesi Tur Dağı'ndaki hadise ile bir tutulur. Hz. Musa'nın peygamber olarak Allah ile konuşması dünyada sadece ona has bir mucizedir. Ancak insanlar için de tecelli farklı şekillerde idrak edilebilir. Galib Bey ve Namık Kemal bu tecelli üzerinde s1klıkla durur.

Galib Bey, tasavvuf anlayışında da divan şiir geleneğini devam ettirmekle birlikte parçadan bütüne giden bir şiir oluşturur:

Zerreler surette mihr-i âlem ârâdır bize

Vâkf-1 mâhiyettiz her katre deryadır bize (sy. 303) (g.105-1)

(Zerreler bizim için anlam bakımından alemi süsleyen güneştir; esas ve asıl olanın (bilgisine) vakıfız, her damla bizim için denizdir.)

Zerrelerdeki tecelliyi gören insan, buradan yola çıkarak kâinatı anlayabilir ve tüm madde ve mana bilgisine sahip olabilir. Allah'ın yarattığı her zerre de nihayetinde kâinatın küçük bir örneğidir. Zerrenin bilgisine sahip olan diğer madde âleminin bilgisine de sahip olabilir. Tasavvuf anlayışında zerreden kâinata gidiş, vahdetten kesrete bir çıkış olarak adlandırılır. Namık Kemal'in gazeli bu anlamı daha açık dile getirir:

Rind-i bezm-i vahdetiz dil câm-1 sahbâdır bize

Neş'e-i idrak feyz-i dîn ü dünyadır bize (sy. 302)

(Vahdet âleminin âşığı için gönül şarap kadehi gibidir. Onun neşesinin anlaşılması ise din ve dünya feyzi gibidir.) Bu gazeli de Namık Kemal, Galib Bey'in gazelini açıklar mahiyettedir. Zerre de vahdetin görülmesinin verdiği neşe din ve dünya yani madde ve mana âleminin feyzi, zenginliğidir. Bu feyzin görüldüğü yer de âşı̆̆ın gönlüdür.

Tasavvuf içerikli şiirlerinde Galib Bey, geleneği devam ettirirken özellikle 17. Ve 18. yy.'ın anlayışını devam ettirir. Özellikle Kur'an-1 Kerim'e yapılan telmihler bakımından oldukça zengin bir içeriğe sahiptir. Bu şiirler hakkında genel bir değerlendirme yapmayı uygun buluyoruz. Galib Bey'in Tasavvufî şiirlerinde vurguladığı anlamı, Namık Kemal ya genişleterek genelleştirir ya da anlamı daraltarak özele indirger. Bunu yaparken Namık Kemal'in daha sade bir dil kullandığını söylemek mümkündür. Galib Bey'in ayet atıflarına rağmen Namık Kemal, doğrudan ayete değil ayetin inme sebebi ya da ayetin ilişkili olduğu hadiseye gönderme yapar. Galip Bey'in "hayf” redifli gazelinde 
"hicâb-1 Lenterâni" (Beni göremezsin örtüsü) şeklinde geçen hadiseyi Namık Kemal şiirinde doğrudan Tur Dağındaki tecelli hadisesi olarak kullanır:

Etmedi ref'-i hicâb-1 Lenterâni yâr hayf (sy. 304) (g.70-1)

Etti hayretle tecelli Tûr-i dilde yâr hayf (sy. 303)

"Ruh" redifli gazelde "leb" mazmunu ile ruh ve canlılık arasında bir ilişki kurulur. Dudaktaki kızıllık canlılığın ve sürekliliğin bir göstergesidir. Bu canlılık ise Allah'ın bir tecellisidir. Galib Bey şiirlerinde tecelli üzerinde sıklıklar durur. Şiirlerinin tamamı incelendiğinde hemen her şiirinde tecelli ile ilgili bir mazmun görülmektedir. Bu gazelde ise "leb" mazmununun klasik kullanımından çıkartılarak ruh ile birlikte bir tecelli yeri olarak alındığı görülmektedir:

Neş’e bahş-i âlem-i lâhût olur sahbâ-yi rûh

Nefha-i lâl-i lebinde var ise eczâ-yi rûh (sy. 305) (g.22-1)

(Eğer) dudağındaki kızıllığın soluğunda ruhtan eser varsa, ruhun kadehi uluhiyet aleminin bağışıının neşesi olur.) kurgular:

Namık Kemal, Galib Bey’in "neşe” üzerine kurduğu gazeli, hayret sözcüğü üzerine

Hayret efzâ-yi ruh cihandır tavr-1 feyz ârâ-yi rûh

Kim olur mevt-i irâdî bâis-i ihyâ-yi rûh (sy. 305)

Hayret; ruhun süsü, feyiz hali, ruh 1şığının dünyasıdır ki ruhun canlanmasının sebebi de hayrettir. Hayret tasavvufî şiirlerde üzerinde durulan bir kelimedir. Tasavvufî̀ bir makam olarak bilinen hayret makamı tecellinin anlaşılması, idrak edilmesi için ulaşılması arzu edilen bir merhaledir. Her şeyde Allah'ın tecellisinin görülmesi, ezel ve ebedin idrakini de kolaylaştıır.

Hz. İsa ve Mesih divan şiirinde başvurulan telmihlerden biridir. Hz. İsa'nın çarmıha gerileceği sırada bedenen ve ruhen göğe yükseltilmesi hadisesi değişik şekillerde ele alınır. "İnsilâh" redifli gazelde Galib Bey, aşk ve Mesih arasında bir bağ kurar. Bu benzetmeye anlam olarak divan şiirinde birçok şiirde rastlamak mümkündür:

Aşk ile ettikçe tenden cân-1 şeydâ insilâh

Unsuriyetten bulur gûyâ Mesihâ insilâh (sy.306) (g.23-1)

(Deli can, aşkla tenden sıyrıldıkça, sanki Mesih maddi varlığından soyunuyor (gibidir))

Aşk, ruhun bedenden ayrılışını bile Mesih'in göğe yükseltilmesi haline getirir. Aşkın âşık üzerinde meydana getirdiği değişiklikler maddeden manaya geçiş için de bir göstergedir. Namık Kemal bu gazeli tanzir ederken Kâbe'nin siyah örtüsünden ayrılmasına benzetir. Aşk, Kâbe ile bütünleşmiş siyah örtünün ondan ayrılması ve kendi olarak kalması gibi insanı bütün maddeden soyutlayarak mana alemine yükseltir:

Perde-i unsurdan etti cân-1 şeydâ insilâh

Kıld1 estâr-1 siyehten Kâ'be gûyâ isilâh (sy. 306)

Aşk ve sevgiliden ayrılışı anlatan diğer bir şiir de "gibi" redifli gazeldir. Sevgilin ayrılışı, cehennem ateş gibi bir şey olsa mahşer ehli gibi âşılar yanıp kül olur: 
Eylese te'sir dûzah nâr-i hicrânım gibi

Ehl-i mahşer mahvolur uşşâk-1 nâlânın gibi (sy. 311) (g.115-1) gibi mahvolur.)

((Ey sevgili) cehennem ayrılığının ateşi gibi tesir edecek olsa, mahşer ehli inleyen aşıkların

Namık Kemal, tanzirinde anlam kapsamından çıkartmadan benzer şekilde tekrarla yetinir:

Dilnişin olsa ecel şemşir-i müjgânın gibi

Mevte âlem can verir uşşâk-ı nâlânın gibi (sy. 310)

((Ey sevgili) ecel, kirpiklerinin kılıcı gibi gönle yerleşecek olsa, âlem inleyen aşıkların gibi ölüme can verir.)

Bu iki şiirde de Namık Kemal, Galib Bey'in üslubunu taklit ederken yine bir tamamlama unsuru olarak kendini gösterir. Kelime dizilişi ve anlam dünyasının oluşmasında Namık Kemal'in yeni bir sesi yoktur.

Kader anlayışını, duanın tesirine bağlayan Galib Bey, "âmâlimi” redifli gazelinde duanın hâlin lisanını sessiz kıldığını vurgular. Kader konusu tartışılan bir konudur. Kaderi değiştiren, yön veren bir nevi dualardır. Gaybı bilmenin imkânsız oluşu duaları daha tesirli hale getirir. Gayb söz konusu olunca da halin yapacağ bir şey kalmaz:

Eyleyen mevkuf-1 te'sir-i niyâz âmâlimi

Şive-i hayretle lâl etmiş lisân-1 hâlimi (sy. 316) (g.118-1)

(Emellerimi duanın tesirine bağlayan hayret edası (içinde) halimin lisanını dilsiz kılmış.)

Namık Kemal'in gazelinde ise divan şiirinin klasik mazmunları kullanılır:

Eyleme teskin yâ Rab cûy-i eşg-i âlimi

Kana kana yâre tafsil eylesin ahvâlimi (sy. 315) anlatsin.)

(Yâ Râb! Izdırap çekenin gözyaşı nehrini durdurma, sevgiliye halimi doya doya açıklasın,

Divan şiirinde âşığın ızdırap çekmesi ve bu ızdıraptan memnun olması, bitmesini istememesi şairlerin ortak olarak kullandığ ettirir. Âşığın ızdırabından gözyaşı dökmesi kendi halini anlatması için en etkili araçtır. Namık Kemal'in gazeli ile Galib Bey'in gazeli burada ayrışır. Namık Kemal gerek üslup gerekse anlam olarak Galib Bey'den çok Fuzuli ile benzerlik kurar.

Galib Bey, divan şiirini canlandırmaya çalışırken Tasavvufî̀ düşünceden de yararlanır. Allah aşk1 üzerinde durduğu şiirlerden "beni" redifli şiirde Allah aşkının insanı nasıl olgunlaştırdığ1 üzerinde durur:

Aşk kim şem'-i haremgâh-1 sıfât eyler beni

Lem'a lem'a mahvedip îsâl-i Zât eyler beni (sy. 317) (g.114-1)

(Aşk beni (Allah'ın) sıfatlarının hareminde (yanan bir) mum haline getirir, (beni) alev alev ortadan kaldırıp (Allah'ın) zatına ulaştırır.)

Namık Kemal de bu anlamda tanzir ettiği şiirinde üslup olarak Galib Bey’in izinden gider: 
Aşk kim vâreste-i kayd-1 sıfat eyler beni

Cezbe-i Hak vâs1l-1 1tlak-1 zât eyler beni (sy. 317)

Bu gazelde Namık Kemal orijinal bir söyleyiş oluşturmaz. Gerek kelimelerin dizilişi gerekse anlam olarak Galib Bey'in gazeli ile arasında bir fark yok denecek kadar azdır. "Cezbe-i Hak" tasavvuf öğretisinde "Hakk'ın kulu kendine çekmesi ve âniden yüce huzuruna yükseltmesi” hali olarak tanımlanmaktadır. Cezbeye giren insan, akıl ve aklın zorunluluklarından tamamen kurtulmuş, Allah'a ulaşmanın şevki ile akıl melekelerini kaybetmiş bir âşığa dönüşür. Bu cezbe, âşı̆̆ı Allah'a ulaştıran bir araçtır.

Namık Kemal'in hak, adalet ve hürriyet kavramları üzerindeki düşüncelerinin oluşmasında ve gelişmesinde Galib Bey’in ayrı bir yeri ve önemi vardır. Bu konuyu işleyen gazellerden biri de "tevfik" redifli şiirdir. Galib Bey;

Adâlettir medâr-1 intizâm-1 âlem-i Tevfik

Mezâlimden olur lerzende arş-1 a'zam-i Tevfik (sy. 322) (g. 72-1) titrer.)

(İlahî yardım aleminin düzen sebebi adalettir, İlahî yardımın büyük arşı zulümlerden (dolayı)

Adaletin dünyadaki düzenin sebebi olarak görülmesi ve adaletsizliğin arşı titrettiğinin ifade edilmesi yeni bir söylemdir. Galib Bey, dünyadaki düzenin asıl sebebi olarak adaleti gösterirken İlahî adaleti vurgular. Tanzimat döneminde özellikle Namık Kemal'in daha sonra yazdığı şiirlerdeki adalet kavramını bu bağlamdan çıkartarak kullandığı da bilinmektedir. Namık Kemal Galib Bey'in bu gazelindeki adalet düşüncesini tanzir ettiği şiirinde kullanmaz. Fakat bu gazelin özellikle Hürriyet Kasidesi'nin yazılmasına kaynaklık ettiğini söyleyebiliriz. Galib Bey, encümen şairlerini gerek üslup gerek fikir olarak yetiştirir. Namık Kemal'in tanzir ettiği şiirin matla' beyti ise şu şekildedir:

Neşât-1 sıdk-1 niyyet dehri eyler hurrem-i Tevfik

Verir bezm-i salâha tâb ü fer câm-1 Cem-i Tevfik (sy. 321)

(Doğru niyetin neşesi dünyanın düzeninin sebebidir, iyilik âlemine İlahî yardımın Cem kadehi güç ve parılttı verir.)

Galib Bey aşk ve hasreti işlediği "renk" redifli gazelinde ise yeni bir benzetme kullanır. Hasret acısının meydana getirdiği yaralar, âşık için kral tacına benzetilir. Bu benzetme Galib Bey'in divan şiirine katkılarından biri olarak görülebilir. Hasret, özlem duygusu âşığa farklı bir hal kazandırır:

Şule-i hasret gelir dâğ-1 serimden renk renk

Müncelîdir cevher-i aşk efserimden (sy. 323) (g.76-1)

(Başımdaki yaradan renk renk hasret alevi gelir; tacımdan renk renk aşkın cevheri pırıldar.)

Namık Kemal de benzer bir gazel oluşturur:

Şu'le dilden cûş eder sevdâ serimden renk renk

K1l nigâh âsâr-1 aşka peykerimden renk renk (sy. 322)

(Başımdaki sevdadan renk renk gönül alevi coşar, yüzümden renk renk aşkın eserlerine bak.)

Galib Bey'in sevgilinin hasreti üzerine kurduğu hayal, Namık Kemal'de doğrudan sevda olarak kullanılır. İkinci mısrada ise Galib Bey'in tâc olarak gösterdiği aşkın belirtisi Namık Kemal'de 
doğrudan yüz ile anlatılır. Bu gazelde de Namık Kemal, Galib Bey'i anlam olarak tamamlamak haricinde özgün bir kullanım gerçekleştirmez.

Aşk konulu gazellerden bir diğeri de "aşk" redifli gazeldir. Galib Bey’in;

Şu'le bâr oldukça gülsitân-1 hüsn ü aşk

Andırır Tûr-i tecellâ-yı cihân hüsn ü aşk (sy. 325) (g.71-1)

(Güzellik ve aşkın gül bahçesinin fidanı alev saçtıkça, güzellik ve aşkın cihanı tecellinin Tur dağını andırır.)

matlalı gazelinde güzellik ve aşk ile Tur Dağı hadisesine telmihte bulunulur. Güzellik ve aşk Allah'ın Hz. Musa ile Tur Dağı'nda konuşması ve oraya tecelli etmesinde nihayete erer. Tur Dağı hadisesi bir kavuşma anıdır. Namık Kemal bu şiire yazdığı tanzirinde miraç hadisesine telmihte bulunur. Hem Tur Dağı hem de miraç hadisesi Allah ile buluşma, görüşme ve konuşmanın yaşandığı iki farklı durumdur. Hz. Musa Tur Dağı'nda nasıl Allah ile görüşmüş ve konuşmuş ise Hz. Muhammed de miraca çıktığında aynı şekilde Allah ile görüşür ve konuşur. İki görüşme arasındaki fark Allah Hz. Musa ile dünya üzerindeki bir mekânda görüşürken Hz. Muhammed ile arşta görüşür. Güzellik ve aşkın tecellisi ise iki şairde de bu hadiselere yapılan telmihle anlatılır. Namık Kemal "aşk" redifli şiirinde güzellik ve aşkı şöyle tanımlar:

Eylemez Cibrîl'i hayret râzdân-1 Hüsn ü aşk

Mebhâs-i mi'racdır sırr-1 nihân-1 Hüsn ü aşk (sy. 321)

"Benim" redifli gazelde ise Galib Bey, yaratılış sırrını anlatır. Hz. Âdem yaratıldığında meleklerin Hz. Âdem'e secde etmesinin istenmesi melekler ve insan arasındaki farkı ortaya koyar. Bütün isim ve sıfatları ile insanı yaratan Allah, meleklerden insana secde etmelerini ister. En güzel biçimde yaratılan insan, gönlünde Allah sevgisi ve inanc1 ile meleklerin bile secde edebileceği bir hale ulaşır:

Ârif'im Bey tül harem kalb-i harabımdır benim

Secdegâh- kudsiyan hâk-i cenabımdır benim (sy. 332) (g.83-1)

(Arifim, Kâbe benim yıkık gönlümdür; meleklerin kıblesi benliğimin toprağıdır.)

Namık Kemal, Kâbe yerine yine miraç hadisesine telmihte bulunur. Doğruluk üzerine yol almak bir miraçtır. Melekler de kulların ölçüsüdür. İnsan aşk ve inançla meleklerden de yüce bir makama ulaşabilir:

Arifim mi'rac şehrâh-1 savâbımdır benim

Kudsiyân peymûde-i pîş-i rikâbımdır benim (sy. 331)

Divan şiirinde vahdet ve vahdet-i vücud konusu sıklıkla işlenir. "Birlik, teklik, bütünlük" (Durusoy, 2012: 430) anlamına gelen vahdet, "kâinattaki her şeyin Allah'ın varlığı ve birliğinden kaynaklanır, O'nun varlığının ve birliğinin ispatıdır" ifadeleri ile özetlenebilir. Galib Bey de vahdeti konu edinir:

Nâr-1 aşkım hânümansûz-i sehâb-1 vahdetim

Nûr-i hüsnüm âb ü tâb-1 âftâb-1 vahdetim (sy. 337) (g.79-1)

(Aşkın ateşiyim, vahdetin (birliğin) her şeyi yakan bulutuyum; güzelliğin ışı̆̆ıyım, vahdet (birlik) güneşinin parlaklığıyım.) 
Kâinat gibi insan da Allah'ın nurundan yaratıldığı için insanı ve kâinatı Allah'tan ayrı bir varlık olarak kabul etmenin yanlış olacağı inancı tasavvufun bir öğretisidir. Galib Bey de şiirinde vahdetin kendindeki tecellisinden bahseder. Bütün varlık âlemi Allah'ın Hz. Muhammed'e olan aşkından yaratıldığı için aşkın en yüce makamı da burasıdır. Namık Kemal'in de gazeli vahdet konusunda tecellinin insan üzerindeki görüntüsünü benzer şekilde ele alır:

Şebnem-i gülzâr-1 aşkım âb ü tâb-1 vahdetim

Behreyâb-1 intisâb-1 âftâb-1 vahdetim (sy. 337)

Galib Bey'in sosyal hayatla ilgili gazelleri de vardır. İnsan duyguları ve toplum arasındaki ilişki, şairin şiirlerinde yer bulur. Arzu ve himmet üzerinde durduğu "himmetim" redifli şiirde "istiğna" anlayışı üzerinde durur:

Ne esir-i matlabım ne Kâmrân-1 himmetim

Hamdülillah müsterih-i imtinân-1 himmetim (Sy. 338) (g.80-1)

(Ne arzunun esiriyim ne himmetin bahtiyarıyım; Allah'a şükür olsun ki himmetin iyiliğini reddettiğim (için) rahatım.)

İnsanın bitmek bilmeyen istekleri onu esir haline getirirken başkalarından gördüğü yardım da onu mutlu eder. Ancak şaire göre bu iki durum da istenen bir şey değildir. İsteklerin esiri olmak ya da himmetle geçinmek sürekli sıkıntı ve mutsuzluğunun da nedenidir. İsteklere esir olmamak ve başkalarından gelecek himmeti reddetmek ona ihtiyaç duymamak rahatlığın nedenidir. Namık Kemal'in gazelinde ise;

Arş-1 tecridim muhit-i sad cihân-1 himmetim

Sâyebân-1 âsmân-1 Lâmekân-1 himmetim (sy. 337) gölgesiyim.)

(Himmet cihanının yüz tarafında tecrid arşındayım, himmetin mekânız gökyüzünün

himmetten medet ummayan bir anlayış sergilenir. Hiç kimseden yardım beklemeksizin bütün beklentinin Allah'tan olması tasavvuf öğretisinin genel amaçları içerisindedir. İnsan kendisine verilenin ve yapılan yardımın Allah'tan geldiğini bilerek kendini dünya nimetlerinden soyutlar. $\mathrm{Bu}$ şekilde gerçek aşka ulaşmış olur.

Hz. İsa'nın göğe yükseltilişi ve kurtarıcı olarak tekrar geleceği inancı divan şiirinin belli başlı konuları arasında yer alır. Mesih olarak da adlandırılan Hz. İsa'nın bu özelliği Galib Bey tarafından da kullanılır. Sevgilinin dudağı Mesih'in mucizeleri için bir çıkış noktasıdır. Cebrail ise sevgilinin bakışından korku içindedir:

\section{Mesîhâ mâye-i i'câz olurken lâ'l-i nâbından}

Herâsandır dil-i Cibril çeşm-i pür itabından (sy. 345) (g.90-1)

(Ey sevgili) Mesih senin saf, tertemiz dudağından mucize mayası alırken Cebrail'in gönlü azarla dolu gözünün (bakışından) korku içindedir.)

Sevgili, dudaklarından çıkan nefes ile ölüleri dirilten Mesih'e benzetilir. Çünkü Cebrail'in Meryem'in eteğine üflediği ruhtan dünyaya gelen $\mathrm{Hz}$. İsa neye dokunsa ona can veren, ölüleri dirilten, körlerin gözünü açan, çamurdan yapılmış kuşlara can verip uçurtan, hasta ve sakat insanları iyileştiren bir peygamberdir. Galib Bey gazelinde sevgilinin dudağının bu özelliği üzerinde durmaktadır. Sevgilinin gözü ise bir afettir, aşığı yok eder. Bakışı ile Cebrail'i bile korkutur. Namık Kemal'in tanzir ettiği şiirinde de sevgilinin bakışı anlatılır: 
Değildir girye peydâ seyr-i rûy-i şu'le tabından

Fürûg-i çeşm-i hasret âb olur tâb-1 hicabından (sy. 344)

Sevgilinin bakışı, âşığı utandırır ve ona duyduğu hasret göz yaşı olarak görünür. Bu gazel Namık Kemal'in kendisini ispat ettiği başarılı gazellerinden biridir. Sevgilinin etkileyici bakışları Galib Bey'in şiirinde Cebrail'i korkuturken, Namık Kemal'de göz yaşlarına dönüşür. Burada oluşturulan hayal dünyası ve mazmunlar oldukça başarılıdır.

Allah'ın yeryüzüne tecelli etmesi, her şeyde O'nun izinin görülmesi ve anlaşılması tasavvufun temel amaçlarından biridir. Galip Bey, tecelli ve Allah'ın madde üzerindeki yaratıcı olarak görülmesi konusunu birçok gazelinde ele alır. Her şeyde Allah'ın tecellisinin izini görmek mümkündür; ancak Allah'1 görmek mümkün değildir:

Nuru tutmuş âlemi mihr-i tecellâ bî nişan

Bağlamış suret cihan ammâ heyûlâ bî nişan (sy. 346) (g.88-1)

(Tecelli güneşinin 1şı̆̆ı alemi (baştan başa) tutmuş (ama kendisinden) iz, eser yok. Dünya surete bürünmüş ama heyuladan (şekilsiz maddeden) eser yok.)

Namık Kemal, Galib Bey'in matla beytinin ikinci mısraına açıklık getirir. Dünya surete bürünmesine rağmen Allah görünmüyor diyen Galib Bey'e Hz. Musa ve Tur Dağı hadisesini hatırlatarak bir çeşit cevap verir:

Müncelî hâtırda aksin cân-1 şeydâ bî nişan

Âlemi nûr-i tecelli tuttu Mûsâ bî nişan (sy. 346)

Âlemi Allah'ın tecellisinin nuru kaplamış; ancak Hz. Musa'dan eser yok. Tecelli ve Hz. Musa birlikte ele alınması gereken bir konudur. Kâinattaki bütün yaratılmışlar tecellinin bir göstergesidir, ancak bu tecelliyi görebilmek gerekir. Hz. Musa ise tecelliyi değil tecellinin asıl kaynağına Allah'a ulaşmıştır.

Sevgilinin bakışı, âşık için can yakıcı, öğretici özellikleri ile bilinir. Âşı̆̆ı kendinden geçiren bakışlar, sevgilinin âşığa olan ilgisinin de bir göstergesidir. Galib Bey, sevgilin bakışı ile deliliğin öğretmeni olarak âş̧ı̆ı gösterir. Sevgilinin bakışı ile kendinden geçerek aklını yitiren Kays (Mecnun)'ın durumu ancak onu gören, onun deliliğine şahit olan ceylanlardan öğrenilebilir:

Sebak âmuz-i esrâr-i cünun ol çeşm-i pür gûdan

Hadis-i sergüzeşt-i kays'1 gel gûş eyle âhûdan (sy. 347) (g.92-1)

(O çok söz(ler) söyleyen (bakışları anlamla dolu) gözden (ders alarak) delilik sırlarının öğretmeni ol; Kays'ın başından geçenlerin haberini ceylan(lar)dan dinle.)

Namık Kemal de sevgilinin bakışları ile bir anlam dünyası oluşturur:

Dil-i feyz iktinâh âşüfte sihr-i çeşm-i pür gûdan

Zebundur şâhid-i i'câzı seyr et dest-i câdûdan (sy. 347)

Sevgilinin anlamlı bakışlarının sihri delilik derecesindeki sevginin kaynağı, gönlün feyzidir. Cadı elinden çıkan mucizeler, şaşırtıcı sözlerin sahibinin sahip olduğu meziyetler karşısında zayıf kalır. Sevgilinin anlamlı bakıșları bir sihir ve mucize gibidir. Sevgilin bakıșları ile ilgili bu mazmunlar divan şiirinde sıklıkla kullanılan mazmunlar arasındadır. Namık Kemal, bu gazelinde divan şiirinin bu geleneğini devam ettirir. 
"Farkına varma, tanıma, kavrama, tasavvur etme, bilme" (Hökelekli, 2000: 477) olarak tanımlanan idrak, beynin bilinçli bir eylemidir. İdrak etmenin en iyi derecesi ise kâinatın sırlarının anlaşılabilmesi, vahdet meselesinin kavranabilmesidir. Bu nedenle de idrak, insan için her şeyden daha önce gelir:

Etmeyiz ümmîd-i himmet cünbiş-i eflâkten

Nâz perverd-i naîmiz âlem-i idrakten (sy. 353) (g.101-1)

(Biz göklerin hareketinden yardım beklemeyiz; biz idrak aleminin cennetinde naz içinde büyütülmüşüz.)

mısralarında Galib Bey, idrakin önemine değinir. Eğer insan kendi idrak edebilirse, başka bir yerden yardım istemek de gereksizdir, gereği de yoktur. Namık Kemal de benzer bir anlamı vurgular. Dünyanın dağdağasından ve karmaşasından bir hikmet görmediğini söyleyen şair, külli aklın idrak gücünden kaynaklandığını belirtir:

Görmedik tavr-1 hikmet cünbiş-i eflâkten

Akl-1 kül var ise kalmış kuvve-i idrakten (sy. 353)

Kur'an-1 Kerim'in ilk suresi olan Fatiha, Kur'an'ın bir özeti olarak kabul edilir. Allah'a hamd etmek ve onun yolunda olmayı isterken sapkınlıklardan kaçınmak için yapılan bir dua gibidir. Özelde Tasavvufî şiirlerin genelde ise divan şiirinin asıl amacı da budur. Allah aşkını öğreterek insanların sapkınlığa sapmasını engellemek, doğru yolda ilerlemelerini sağlayabilmek divan şairlerinin ortak düşüncesini oluşturur. Galib Bey’de şiirini bu amaca bağlar:

Keşk-i esrâr-1 cünun i'câzıdır efkârımın

Sûre-i Seb’ul mesâni şerhidir güftârımın (sy. 356) (g.75-1)

(Deliliğin sırlarını keşfetmek, fikirlerimin mucizesidir; Fatiha suresi (benim) sözlerimin açıklamasıdır.)

Aşk, âşı için sürekli ilerlenmesi gereken bir süreçtir. Âşık, aşkta öyle bir dereceye gelmelidir ki kendisini ve varlık sebebi olan yuvasını bile yakabilmelidir. Kendinden ve sevdiği, önem verdiği her şeyden kopabilen âşık, aşkın en yüce mertebesine ermiştir. Galib Bey, gül bahçesi olan yuvasını yakan kuş benzetmesi ile aşkın en üst mertebesine işaret eder. Âşı ğı, âşı sebeplerden geçerek ancak Allah aşkına ulaşılabilir:

Mürg-i gülşen sûz-i aşk ol âşiyanın kalmasın

Âlem-i bâlâya pervâz et nişânın kalmasın (sy. 357) (g.96-1)

(Aşkın gül bahçesini yakan kuş ol, yuvan kalmasın; yüce alem(ler) uç, nişan kalmasın.)

Namık Kemal de aşk ateşi ile yanıp her şeyden geçerek gerçek aşka ulaşmaktan bahsedir. Cisim ve candan geçen insan mahviyete, alçakgönüllülüğe ulaşır. Maddenin bittiği yerde mana başlar. Bu dereceye ulaşan âşı̆̆ın Allah’a ulaşmak için önünde hiçbir engel kalmaz:

Sûziş-i aşk ile mahv ol cism ü cânın kalmasın

Tâ sırât-1 haşra bir bâr-1 girânın kalmasın (sy. 356)

"Duymasın" redifli şiire birçok divan şairinde rastlamak mümkündür. Tezat sanatı ile oluşturulan gazellerde âşığın aşkından ne sevgili ne de kendi canının haberi olmasın şeklinde özetlenebilecek bir anlam söz konusudur:

Terk-i cân et tut reh-i cânânı cânın duymasın 
Aşk ile mahvol vücûd-i nâtûvânın duymasın (sy. 357) (g.93-1)

(Canını terk edip sevgilinin yolunu tut(ama) canın duymasın. Aşkla perişan ol (ama) güçsüz vücudun duymasın.)

Namık Kemal bu gazeli anlam ayırdına gitmeden benzer tonda tanzir eder. Canın sevgili için defa edilmesi âşığın hep istediği bir fedakarlıktır. Ancak bu fedakarlığın anlam kazanabilmesi için âşığın bu fedakarlığından sevgilinin haberin olmaması arzu edilir:

Bahş-i cân et yâra cism-i nâtüvânın duymasın

Cevr ile bin pâre olsun istühânın duymasın (sy. 357)

Gül ve bülbül mazmunlar divan şiirinin olmazsa olmazı olarak görülür. Birçok şiirde âşık ve mâşuğun anlatılmasında bu mazmunlardan yararlanarak bir hayal dünyası oluşturur. Aynı zamanda bu ikili arasındaki aşka Tasavvufî anlamlar da yüklenir. Galib Bey de gül ve bülbül arasındaki ilişkiye bu bakımdan yaklaşır:

Andelibân zâr olur verd-i handânım görüp

Gönceler eyler hased çâk-i girîbânım görüp (sy. 367) (g.18-1)

(Bülbüller o gülümseyen gülümü görüp ağlar; goncalar yakamın yırtığını görüp kıskanır.)

Namık Kemal, "görüp” redifli Galib Bey’in gazeline yazdığı tanzirinde;

Aybeden sevdâ-yi aşkı sûz-i hicrânım görüp

Âteş-i gayretle yansın şimdi cânânım görüp (sy. 366)

Ayrılık ateşini görüp aşkın sevdasına ayıp eden, sevgilimi görüp gayret ateşiyle yansın. Ayrılık âşığın istemediği ama ayrılık acısından dolayı mutlu olduğu bir haldir. Âşı̆̆ın bu ayrılık acısını görerek aşktan uzak duranların bu hali anlaması ihtimali yoktur. Âşığı zinde tutan sevgiliden ayrı olup ona ulaşabilmek için çaba göstermektir. Âşığı ayrılık ateşi ile yanarken görüp onu eleştirenler, sevgiliyi görseler ona hak vereceklerdir.

Aşkın verdiği acının boyutları da divan şiirinde faklı şekillerde ifade edilir. Galib Bey'in "bir" redifli gazelinde beden ve kalp arasında bir ayrım yapar. Acıyı çeken vücuttur. Ancak bu acıdan habersiz sevmeye devam eden kalptir. Bu, yaralar içinde olmasına rağmen sabır içinde acı çekmeyen Hz. Eyüp'ün durumuna benzemektedir:

Sine pür zahm-1 havâdis cân-1 şeydâ bî haber

Ten harâb âbâd Eyyûb-i şikîbâ bî haber (sy. 371) (g.25-1)

(Sine hadiselerin yarasiyla dolu(dur); deli can (ise) habersiz (dir); ten harab halde(dir); sabırlı Eyüp (ise) habersizdir.)

Hz. Eyüp divan şiirinde sabrın örnek kişisidir. Vücudundaki hastalıktan, kurtlardan hiç şikâyet etmeyen Hz. Eyüp, bu hastalıkların ve kurtların en sevgiliden, Allah'tan geldiğini bildiği için sabreder. Sevgilin verdiği ızdıraba dayanmanın aşkı yücelttiği anlamı, Hz. Eyüp hadisesine yapılan telmihlerle vurgulanmaktadır. Namık Kemal, Galip Bey'in gazelini tanzir ederken yine zitlıklardan yararlanır:

Sinede kayd-1 taalluk cân-1 şeydâ bî haber

Hâr-1 sûzen dâmenin tutmuş Mesîha bî haber (sy. 371) 
Galib Bey'in Hz. Eyüp kıssasına telmih yapmasına karşın, Namık Kemal ölüleri diriltme mucizesi gösteren Hz. İsa'ya, Mesih'e telmihte bulunur. Âşıı̆ı̆n bu halinden ne sevgili, ne de Hz. İsa haberdardır.

Vahdet ve kesret meselesinin işlendiği diğer bir şiir de "bir" redifli gazeldir. Galib Bey;

Suret-i sırr-1 heyula muhtelif eczâsı bir

Cünbiş-i nûr-i tecellâ muhtelif mecrâsı bir (sy. 377) (g.44-1)

(Heyulanın (şekilsiz maddenin) sırrının sureti çeşit çeşitken, (bu suretleri meydana getiren) karışım birdir. Tecelli nurunun hareketi çeşit çeşitken geldiği aktığı yer birdir.)

mısralarında maddenin çeşit çeşit olmasına rağmen onu yaratanın birliği, tek elden yaratılmış olması vahdetin bir göstergesidir. Allah, kâinatta ayrı ayrı tecelli eder, ayrı ayrı görünür ama bu çeşitliliğin çıkış noktası tektir. Namık Kemal'in şiirinde de aynı anlam dünyası görülür:

Âlem-i fitrat ki olmuș mâye-i eczâsı bir

Görünür her suret ile cevher-i meclâsı bir (sy. 377)

Madde farklı farklı görünse de her şeyin mayası birdir. Allah'ın birliği ve vahdet sıfatı madde üzerinde faklı farklı görünür. Bu farklı görüntüye rağmen Allah'ın birliğini bu çokluk içinde görmek mümkündür.

Kader konusu da zaman zaman divan şiirinde üzerinde durulan bir konudur. Zamandan, felekten şikâyet ise şairlerin genel olarak şikâyet ettiği varlıklardır. Zamanın ilerlemesi kaderi de sürekli değiştirir. Her yaşanan an, insan için farklı bir imtihan olarak karşısına çıkar. Galip Bey'in şiirinde bahtsız bir talih söz konusudur:

Necm-i bahtım gerdş-i devrândan rencidedir

Hayf gevher cuşiş-i ummândan rencidedir (sy. 378) (g.33-1)

(Talih yıldızım, devranın dönüşünden incinmiştir. Yazık (ki) cevher denizin dalgalanmasından incinmiştir.)

Namık Kemal ise konuya farklı bir açıdan yaklaşır:

Aks-i hüsnün dîde-i giryândan rencîdedir

Goncamız ebr-i bahâristândan rencidedir (sy. 377)

Güzelliğin yansıması göz yaşından incinmiştir. Gonca ise bahar yağmurlarından incinmiştir. Güzelliğin sudaki aksi gözyaşının damlaması ile kaybolur. Gonca da yağmur tanelerinden etkilenir. Güzellik, kendisi için çekilen acıdan, ızdıraptan etkilenir. Âşık için de durum aynıdır. Sevgiliye ulaşabilmek için acı çeken göz yaşı döken âşık, bu göz yaşının sevgiliyi incitebileceğinden habersizdir.

“Kâlu Bela” olarak bilinen ruhların Allah'ın Rab'liğini ve birliğini kabul ettiği an, insan için bir yemin ve kabul anıdır. Ruhun o anda verdiği söz ve kabul Tasavvufî şiirlerde özellikle üzerinde durulan bir olgudur. İnsanın o sözü hatırlaması ve ona uygun olarak yaşaması gerektiği bu şiirlerin ana konusunu oluşturur. Galip Bey'in "demdir redifli gazelinde de bu konudan bahsedilir:

Anılsın ol belâ ahdi ki mey nûş ettiğim demdir

Cam-1 dünyâ vü ukbây-1 ferâmûş ettiğim demdir (sy. 383) (g.43-1)

(O bela (evet) yemini (ni ettiğim zaman) anılsın, (ki o zaman) şarap içtiğim, dünya ve ahiretin üzüntülerini unuttuğum zamandır.) 
Bela zamanı, âşık için aşk şarabının da içildiği ve bütün üzüntülerin unutulduğu bir zamandır. Galip Bey, İlahî aşk şarabının içildiği ve aşk sözünün verildiği anı hatırlatır. Namık Kemal ise bela zamanını "hengâme-i vahdet" olarak isimlendirir:

Zehî hengâme-i vahdet ki mey nûş ettiğim demdir

Rüsum-i küfr ü imânı ferâmuş ettiğim demdir (sy. 383)

İnsanların Allah'ın varlığını ve birliğini kabul ettiği an, küfür ve imanın bile unutulduğu sadece vahdet düşüncesinin olduğu bir zamandır. Namık Kemal, tanzir ettiği şiirde sadece kavramları değiştirmekle yetinir.

Galib Bey, gazellerinin birçoğunda İlahî aşk1 konu edinir. Divan şiirinin oluşturduğu mazmunlardan olabildiğince yararlanır. Sevgilinin kaşını, Kur'an'daki Bismillah kelimesindeki uzatma işaretine benzetir. Şair, bu benzetmeyi de yapabilmenin ve Allah'nn cemalinin görülebilmesinin ancak Allah'ı bilen arifler tarafından gerçekleşebileceğini ifade eder.

Mushaf-1 hüsnünde ebrû medd-i bismillâhdır

Vâkıf-1 sırr-1 cemâlin ârif-i billâhdır (Sy. 390) (g.37-1)

(Kaş, güzelliğinin Kur'an'ında bismillah (kelimesindeki) uzatma (işaretidir); senin Cemal'inin sırrına vakıf (olan) Allah'ı bilen ariftir.)

Namık Kemal, Hz. Muhammed'e atıf yaparak iyiliğin nüshası ve peygamberin sıfatı olarak Bismillah kelimesini gösterir. Onun üzerindeki teni ise Allah'ın ayni bir tecellisi olarak görür. Kâinatın yaratılmasının amacı da Hz. Muhammed'in varlığı ve kulluğu olarak düşünüldüğüne Namık Kemal'in bu anlamı vurgulaması tasavvuf anlayışına uygundur:

Nâm-1 Ahmed nüsha-i icâde Bismilâh'dır

Pence-i âl-i abâ ayniyle bir Allah'dır (sy. 389)

Gönül, sevgilinin mekânıdır. Bu nedenle divan şiirinde gönül gül bahçesi olarak anılır. Galib Bey, gül bahçesi mazmununu yeniden ele alarak aşk baharı için sığınılacak bir mekân olarak ele alır. Bahar ancak bu gönülde yerini ve zamanını bulur. Gönül bu özelliği ile sonsuzluğu temsil eder. Dünyanın ve insanların sonu ve yeniden diriltilmesi olarak bilinen mahşer zamanı, Galip Bey tarafından aşkla dolu gönül için bir güzellik olarak ele alınır. Mahşerin yakıcı güneşi âşığın gönlüne zarar vermez; sadece kırmızı bir lale olarak yer alabilir.

Dil bahâr-1 aşkımın kim gülşen-i me'v'asıdır

Mihr-i mahşer bir muhakkar lâle-i hamrâsıdır (sy. 391) (g.31-1)

(Gönül, aşkımın baharının sığınılacak gül bahçesidir; mahşer güneşi (o bahçenin) küçük, k1zıl bir lalesidir.)

Namık Kemal'in şiirinde ise Leyla ve Mecnun aşkına gönderme yapar:

Şimdi deşt-i vahdetin dil kays-1 bîpervâsıdır

Halka-i tevhîd çîn-i turra-i Leylâ'sıdır (sy. 391)

(Gönül, vahdet elinin pervasız Kays'ıdır. Tevhid halkası, Leyla'nın mührünün kıvrımlarıdır.)

Kays'ın Leyla'ya olan beşerî aşkı, ilahî aşka dönüşür. Kays, Leyla'ya kavuştuğunda ondan geçer ve Allah aşkını bulur. Beşerî aşkın ilahî aşka dönüşmesi ise maddeden manaya bir geçiş ve vahdetin, sevilmeye değer tek varlığın Allah olduğunun bir göstergesidir. Şair, Leyla'ya olan aşkı, vahdet ile açıklar. Leyla, Kays için Allah aşkının bulunduğu bir sevgilidir. Namık Kemal ve Galib 
Bey'in gazellerinde üslup benzerliği görülse de Galib Bey'in gazeli orijinal bir hayal dünyasının izlerini taşır.

Leyla ve Mecnun aşkının konu edildiği Tasavvufî şiirlerden biri de "aşkındır" redifli gazeldir. Leyla ve Mecnun, ilahî aşkın işlendiği şiirlerde şairlerin sıklıkla kullandığı mazmunlardan biridir. Galib Bey'de gazellerinde bu mazmunlardan yararlanır:

Reh-i firkatte sanma Kays-1 dil gümnâm-1 aşkındır

Gelen her berk-i kabrimden sedâ-yi nâm-1 aşkındır (sy. 394) (g.34-1)

(Gönül, Mecnun'u senin aşkından dolayı ayrılık yolunda adı, sanı unutulmuş zannetme, mezarımdan gelen her şimşek senin aşkının hatırasının sesidir.)

Mecnun'un Leyla'ya kavuşamaması, kavuşacağı an ölmesi hikâyenin en acıklı bölümüdür. Bir ömür Leylâ'ya kavuşma hayaliyle dolaşan Mecnun, kavuşacağı an ölür ve ayrılık devam eder. Kavuşmaları ancak ahirete kalır. Bu nedenle Leyla ve Mecnun hikayesi kavuşulamayan aşkın mazmunudur. Şair, bu beyitte Mecnun'un ölmesi ile birlikte adının unutulmadığını, mezarında bile aşkının devam ettiğini söyler. Mecnun'un aşkı ebedi sürecek bir aşktır. Bitip yitmediği için beşerî aşk, ilahî aşka dönüşür. Namık Kemal aynı redifli gazelinde aşkın sonsuzluğunu doğrudan dile getirir:

Harîm-i Lâmekan bezm-i neşât encâm-1 aşkındır

Zemin ü âsman dürd ü habâb-1 câm- aşkındır (sy. 394)

(Başıboş kimse, muhabbet meclisi, aşkın sonudur. Yer ve gök aşkın tortusu ve kabarcı̆̆ıdır.)

Kâinatın yaratılış gayesine değinen şair, yeri ve göğü aşkın iki öğesi olarak değerlendirir. Yer tortusu, gök ise kabarcı̆̆ıdır. Bu ikisi arasındakiler de aşkın birer parçasıdır. Kainattaki her şey aşk ile açıklanabilecek unsurlardır. Namık Kemal'in burada yer ve gök için kullandığı benzetmeler, onun divan şiirindeki usta kullanımları arasındadır. Bu benzetmenin divan şiirine yeni bir hayal dünyası kazandırdığını söylemek mümkündür.

“Enelhak (ben Allah'ım)" Tasavvufî şiirlerde kullanılan bir söylemdir. Allah'ın kâinatı kendi nurundan yaratmış olması, her şeyin yaratılışında bizzat tecelli etmesi, insanın yaratılmasında da bütün isim ve sıfatları ile kendini göstermiş olması tasavvufî düşüncede Allah'tan başka bir şey yoktur, her şey O'dur anlayışını oluşturur. Bazı görüşler bu düşünceyi sakıncalı görseler de divan şiirinde zaman zaman bu anlayışa yer verilir. Galib Bey de bu anlayışa şiirlerinde yer verir:

Eyle ey mihr-i tecellâ çeşm - cânımdan zuhur

Eylesin sıth-1 enelhak tâ zebanımdan zuhur (sy. 396) (g.30-1)

(Ey tecelli güneşi, canımdan ve gözümden görün; ta (ki) enelhak (ben Hakk'ım) sesi dilimden ortaya çıksın.)

Şair, Allah'ın insan üzerindeki tecellisini görüp kendisini de Allah(tan) görmenin, o mertebeye yükselmenin isteği içerisindedir. Namık Kemal, tanzir ettiği gazelinde Galib Bey ile aynı düşünceyi paylaşmaz:

Sûz ü tâb-1 berk-1 hüsn ettikçe cânımdan zuhur

Bin gül-i hurşîd eder her katre kanımdan zuhur (sy. 395)

(Güzellik şimşeğinin ışığı ve ateşi canımdan ortaya çıktıkça, her damla kanımdan bin güneş (gibi) gül ortaya çıkar.) 
Güzelliğin ortaya çıkışı Allah'ın Cemal sıfatı ile açıklanır. Cemal isminin tecellisi güzelliğin ortaya çıkması ve görünmesinin temel kaynağıdır. Kalp de hem maddi hem de manevi olarak güzelliği ortaya çıkartan ana merkezdir. Her damla kanda güzelliğin ortaya çıkması, Namık Kemal'in divan şiirinin hayal dünyasına kazandırdığı yenilikler arasındadır.

“Olur” redifli gazelde de benzer bir anlam söz konusudur. Allah'ın kâinatı yaratırken hareketi varlık âlemi için bir lütuftur. Allah lütfederek yaratır. Galib Bey lütfu iki türlü değerlendirir:

Gelse lütfun yâde hem mevcûd hem nâbud olur

Kîmyâ dünyâde hem mevcûd hem nâbûd olur (sy. 396) (g.26-1) olur.)

(Lütfun hatıra gelse hem var hem yok (gibi) olur. Kimya dünyada hem var hem yok (gibi)

Allah lütfu ile yoktan var ederken madde yoktur. Sebepsiz ve maddesiz bir yaratıllıs söz konusudur. Bununla birlikte yaratılış esnasında Allah önce sebepleri, maddeyi yaratarak, yaratılış1 bu sebeplere bağlar. Yaratılış sırrı, kimya ile açıklanabilse de asıl sır Allah'ın lütfundadır. Namık Kemal de benzer bir şiir oluşturur:

Gelse la'lin yâde hem mevcûd hem nâbud olur

Kim âdem-hal yâde hem mevcûd hem nâbud olur (sy. 396)

(Dudağın hatıra gelse hem var hem yok olur ki âdemin hali hatıra gelse hem var hem yok olur.)

Sevgilinin dudağının hatıra gelmesi ile varlık ve yokluk aynı anda görülür. Sonsuzluğu temsil eden sevgilinin dudağı, ebediyet anlamıyla divan şiirinde yer alır. İnsanın hali de varlık ve yokluk arasındadır. Tecellinin iki ayrı durumu bu şiirde de yer alır. Kâinat bu zıtlığın bir yansımasıdır.

Dini terminolojide yer alan bazı terimler, divan şiirinde bağlamından kopartılarak daha geniş anlamıyla kullanılır. Bu özellikle tasavvufî şiirlerde görülen bir uygulamadır. Mucize de bu kelimelerden biridir. Peygamberlere verilen akıl yoluyla açıklanamayan, doğaüstü olay anlamına gelen mucize, insanlar için etkileyici ve şaşırtıcı bir eylemdir. Galib Bey "olur" redifli gazelinde sevgilinin gözünün büyüsünü mucize ile kıyaslayarak gösterir. Sevgilinin gözünün büyüsü, mucizeden daha etkileyicidir. Ölüleri diriltme mucizesi gösteren Hz. İsa'nın kullandığı iğne de o büyüleyici göz için kirpik gibidir. Mucize ve Hz. İsa'nın ölüleri diriltme özelliğine telmihte bulunan şair, sevgilinin gözünün büyüsünü orijinal bir kıyaslama ile anlatır:

Sihr-i çeşme-i şuhuna i'caz kim hayrân olur

Süzen-i Îsâ nigâh-1 nâzına peygân olur (Sy. 397) (g.46-1)

(Mucize (o) şen şakrak gözünün büyüsüne hayran olur. İsa'nın iğnesi nazının bakışına (ok temrenini andıran) kirpik olur.)

Namık Kemal, sevgiliyi divan şiirinin klasik mazmunlarını kullanmayı tercih eder:

Nâveg-i sehm-i saâdet gamzene peygân olur

Reşg o âlî bahta kim peygânına kurbân olur (sy. 397)

(Saadet oku, sevgilinin gamzesinde oku ucu gibi durur. O yüce bahtlıya kıskanma ki o senin okuna kurban olur.)

Sevgilinin gamzesi, divan şiirinde âşı̆̆ baştan çıkartan, anlamlı, hüzünlü, süzgün bakış olarak kullanılır. Saadet, mutluluk sevgilinin bakışlarında gizli olsa da, saadet bile sevgilinin o bakışı karşısında kendini kaybeder. Saadet, sevgilinin bakışı karşısında kendisini kurban edecek kadar 
etkilenir. Sevgilinin bakışı ile sevgilinin âşığa olan ilgisi arasında sıkı bir bağ vardır. Âşı̆̆ı kendinden geçiren bakış, onu sevgiliye ulaştırmak için itici bir güçtür. Namık Kemal, Galib Bey'de olduğu gibi orijinal benzetmeler yerine divan şiirinin genel anlayışına uymakla yetinir.

Âşık ve sevgili arasındaki aşk ve arzu değişik şekillerde ele alınır. Galib Bey'in yine "olur" redifli gazelinde de bu durum ele alınır. Âşığın gönlü çoşsa, sevgiliye ulaşamamanın verdiği kederden çıkan "ah"lar cehennem alevi ile birlikte görünür:

Âteş-i aşkın dilimde her ne dem pür cûş olur

Mürg-i âhım şu'le-i dûzahla hem âgûş olur (sy. 400) (g.38-1)

(Aşkının ateşi gönlümde ne zaman coşsa artsa, ahımın dumanı cehennemin aleviyle kucak kucağa olur.)

Bu anlamı Namık Kemal sıkça kullandığı Tur Dağı mazmunu ile dile getirir:

Hayret-i berk-i cemâlinden ki dil bîhuş olur

Nûr-i çeşmim Pertev-i Tûr ile hem âguş olur (sy. 400)

(Gönül, yüzünün şimşeğinin hayretinden kendinden geçer. Gözümün nuru, Tûr (Dağı)'nın 1şığı ile kucak kucağa olur.)

Sevgilinin yüz güzelliğini ön plana çıkartan Namık Kemal'in bu gazeli Galib Bey'in gazeli ile karşılaştırıldığında daha sönük kalır. Tur Dağı benzetmesi ise birçok şiirde kullanılan anlamından farklı bir hayal oluşturmaz. Allah'ın Hz. Musa ile konuşmasının mekânı olan Tur Dağı'nın, tecellinin gerçekleştiği andaki nuru, 1şığı âşığın sevgilinin yüzünü gördüğü andaki 1şı̆̆ı ile denktir.

Sevginin ve aşkın farklı dereceleri olduğu bilinir. Aşktaki en yüksek mertebe ise ihlas (samimiyet)tir. Sevgiliye karşı sevginin, aşkın samimi bir şekilde ifadesi, gösterilmesi âşığın sevgili karşısında değer kazanmasını sağlar. Bu samimi duruş, sevgili karşısında diğer sahte sevgileri de kendinden uzaklaştırır, yok eder. Galip Bey, "ihlas" redifli gazelinde ihlas ve samimiyeti şu şekilde anlatır:

Olunca râyet efrâz-1 melâmet dâver-i ihlâs

Olur âlem serâser pâymâl-i leşker-i ihlâs (sy. 402) (g.68-1)

(İhlas (samimiyet) hükümdarı kınanış bayrağını çekince alem baştan başa ihlas askerinin ayakları altında kalır.)

Namık Kemal ise ihlası doğrudan kendi bağlamında kullanır:

Tarîk-1 Hak'ta câna aşk olunca rehber-i ihlâs

Açar her çâk-i sinem sûy-i arşa bir der-i ihlas (sy. 402)

(Cana, Hak yolunda aşk rehber olunca, sinemin her parçası arşa bir ihlas kapısı açar.)

Aşk ve ihlası bir arada tutan şair, ihlasın, samimiyetin kendi üzerindeki etkilerini konu edinir. Aşkla parça parça olmuş gönül, eğer ihlasla dolarsa her bir parçasından o zaman arşa ulaşmak kolaydır. Galib Bey'in aşkla birlikte âlemin baştan başa ihlasla dolacağını ifade etmesi karşısında Namık Kemal bu genel anlamdan sıyrılarak gönül üzerine daha dar kapsamda bir anlam dünyası oluşturur.

Aşkın tarif edildiği "eylemiş" redifli gazelde; 
Aşk kim mülk-i dili derd ile vîrân eylemiş

Her tehi gencînede bin gene pinhân eylemiş (sy. 404) (g.62-1)

(Gönül ülkesini dertle alt üst eden aşk, her sakin köşesinde yüz binlerce hazine saklamış.)

aşkın gönülde bıraktığı kalıcı etkiden bahsedilir. Galib Bey, bazı gazellerinde yeni tarzlar, yeni kullanım arayışlarında olsa da bazı gazellerinde divan şiirinin başarılı bir takipçisi olur. Gönül ülkesinin aşkla viran oluşu, aşkın gönülde hazineler bırakması bu anlayışın bir ürünüdür. Namık Kemal yine tanzir ettiği bu şiirde şiiri anlam olarak açmayı tercih eder. Galib Bey'in mülk-i dil olarak belirlediği yer, Namık Kemal'de iman ve küfür olarak görülür. Aşk, iman ve küfrü birlikte mahvederek onların yerine sadece kendisi kalır:

Aşk kim mahv-i rüsum küfr ü îmân eylemiş

Sad hezeran Kâ'be vü büthane viran eylemiş (sy. 403)

"Göstermiş" redifli gazelinde Galib Bey, kâinat ve insan üzerinde durur:

Hudâ kim nüshâ-i kevni edüp tanzim göstermiş

Kitâb-1 hikmetinden âdeme bir mîm göstermiş (sy. 404) (g.63-1) göstermiştir.)

(Kâinat yazısını düzenleyip ortaya çıkaran Allah, insana hikmet kitabından bir mim (harfi)

Divan şiirinde mim harfi şekil olarak ağza benzetilir. İnsanın konuşabilme özelliği onu diğer varlıklardan üstün kılan bir özelliktir. Bu nedenle şair ağzı hikmet kitabından bir parça olarak görür. Aynı zamanda kâinatın yaratılma nedeni olan Hz. Muhammed'in isminin baş harfi de "mim"dir. Hikmetin öğrenilmesi için Hz. Peygamberin öğretileri ve hayatı bir yol göstericidir. Allah, insanlara kendini ifade edebilmek için Hz. Muhammed'i bir vasıta olarak yaratır. Hz. Muhammed, Allah'ın sözlerini insanlara getiren seslendiren bir "ağız" gibidir. Namık Kemal, tanzir ettiği gazelde Galib Bey'in vurguladığı bu anlamı biraz daha açar:

Tekellüm cevher-i ferd-i dehânın nîm göstermiş

Hakîm-i Lâyezâli bir acep taksîm göstermiş (sy. 404)

(Konuşmak insan ağzının cevheridir ki bu (inşadaki cevherin) yarısını gösterir. Ebedi Hakîm (olan Allah) bir acayip taksim göstermiş.)

Diğer varlıklar arasında konuşma kabiliyetine sahip tek varlık insandır ve bu özelliği onun en önemli ayırt edici özelliğidir. Düşünmek ve düşündüklerini dile getirmek insan için bir hazine değerindedir. Şair, konuşma özelliğini insana verilen cevherin yarısı olarak adlandırır. Allah, insana kendisinde de olan bu özelliği vererek bir taksim gerçekleştirir. Bu, şairin anlamak da zorluk çektiği bir sirdır.

Şairlerin zamandan ve insanlardan, bozulan ahlaktan şikâyet etmesi de sik rastlanan bir konudur. Zamanın değer yargılarındaki değişiklikler şairlerin dikkatini çeker ve eleştiri oklarının hedefi olur. Galib Bey de zamandan ve ahlakın bozulmasından şikâyet eder:

Şime-i âlemde insâf ü mürüvvet kalmamış

İnhiraf etmiş tabiat istikamet kalmamış (sy. 405) (g.66-1) kalmamıştır.)

(Alemin huyunda insaf ve iyilikseverlik kalmamıştır. Yaratılış bozulmuş doğruluk 
Toplumda merhamet duygusunun ve iyilikseverliğin azalması, insanın yaratılışına uygun hareket etmemesi bir yaratılış bozukluğu olarak görülmektedir. Namık Kemal de benzer bir eleştiri de bulunur. İnsanların davranışlarında hikmetin kalmaması bir başıboşluğun göstergesidir. Hikmetli davranmak aklın ürünüdür. Şair, bu dengeyi kurar. Hikmetsiz, amaçsız davranışlar insanların akla, mantığa uygun davranmamalarının bir sonucudur:

Âlemin tavrında hiç âsâr-ı hikmet kalmamış

Akl-i fa'âlin meğer hükmünde kudret kalmamış (sy. 405)

"Arş" redifli gazel ise yine sevgilinin güzelliğini anlatan bir gazeldir:

Ey serir-i izz ü nâz-1 zîver-i dîvan-1 arş

Devletinden irtira'-1 şan bulur eyvânı-1 arş (sy. 406) (g.61-1)

(Ey şeref ve naz tahtında arş divanının süsü olan (sevgili), Arş’ın kemerinin şanı senin yüksek derecenden dolayı yükselir.)

Sevgili, şeref ve âşığa yaptığı naz ile bulunduğu yere de değer kazandırır. Mecazi olarak "hükümranlık, şan ve taht" (Yavuz, 1991: 406) anlamlarına gelen arş, sevgili ile birlikte değer kazanır. Namık Kemal de benzer bir ifade kullanır. Sevgilinin güzelliği arşın şanının cilvesi olsa, arş haşre dek titrer:

Olsa ger ikbâl-i hüsnün cilvesâz-1 şân-1 arş

Dehşetinden haşre dek lerzân olur bünyân-1 arş (sy. 406)

Sevgilinin aşk kılıcıyla yaralanan âşı için merhem gerekmez. Âşık sevgiliden gelen her cefaya razıdır. Sevgilinin açtı̆̆ yaranın iyileşmesi de arzu edilmez; çünkü âşı onunla mutludur. Yara sevgiliyi, onun ilgisini gösteren bir izdir. Galib Bey'in "istemez" redifli şiirinde bu durum söz konusudur:

Mecruh-1 tîg-1 aşkın olan merhem istemez

Dilküştegân-1 şehr-i belâ mâtem istemez (sy. 415)

(Ey sevgili) aşkın kılıcıyla yaralanan (iyileşmek için) merhem istemez; bela şehrinin gönül şehitleri arkalarından matem istemez.)

Namık Kemal de gönülde sevgilinin açtığı yaradan kurtulmak istemez. Tur Dağı'na telmihte bulunan şair Tur Dağı'nda tecelli nurunu gören gül yaprağının canlılık için nasıl su taneciğine ihtiyacı olmazsa gönüldeki aşk yarası da tecelli nuru gibi âşığa hayat verir:

Sinemde dâg-1 şu'lefeşan merhem istemez

Gülberg-i bâg-1 Tûr eser-i şebnem istemez (sy. 415)

Âşık için sevgilinin güzelliği, varlığı, âşıkla olan ilgisi âşığın tek hayat kaynağıdır. Âşık cennete bile gitse sevgili ona küsse oradan zevk almaz, canı hiçbir şey yapmak istemez. Çünkü onun varlık sebebi, neşe kaynağı sevgilidir. Sevgili olmadan ne cennet ne de rahat âşık için söz konusu bile değildir:

Cihan dâr-üs-selâm olsa gönül bîzârdır sensiz

Hayâl-i hâb ü râhat dûş-i fikre bardır sensiz (sy. 421) (g.54-1)

(Cihan cennete dönse bile gönül sensiz her şeye küskündür. Sensiz rahat uyuyabilme hayali düşüncenin omuzuna yüktür.) 
Galib Bey'i anlam olarak takip eden Namık Kemal, sevgilisiz bir hayatın kendi üzerindeki etkisini anlatmayı tercih eder:

Dil-i mecruhuma rûh-i mücerred bârdır sensiz

Tenim bâlîn-i gamda şöyle bir bîmârdır sensiz (sy. 421)

(Yaralı gönlüme sensiz ruhum yüktür, vücudum gam yastığında sensiz hastadır.)

Âşık sevgili olmadan yaşamdan keyif almaz. Onun varlık sebebi sevgilidir. Sevgili yoksa âşı için yaşamak bir yüktür.

Galib Bey'in yine aşk konu edindiği;

Tâb-1 aşk ile o âteştir dil-i bî sudumuz

Kim çerağ efrûz-i mahşerdir gubâr-i dudumuz (sy. 426) (g.56-1)

(Boş gönlümüz aşkın kuvvetiyle yanan ateştir; o ateşin dumanının alevli tozu mahşerin fitilini tutuşturur.)

Gazelde aşkın âşıkta meydana getirdiği değişimi anlatır. Aşk ateşi, âşığın gönlünü öyle bir yakar ki bu ateşin tozu mahşerin ateşini tutuşturur. Namık Kemal'in bu iki gazeli divan şiirinin genel anlayışına uygun bir tekrardır. Ancak âşık ve sevgili arasındaki bağın anlatılması bakımından oldukça başarılı şiirlerdir.

"Hayat" redifli gazelde de Galib Bey sevgili ve âşık arasındaki karşılıklı ilişkiyi konu edinir:

Sunsa el hançere ol âfet-i devrân-1 hayât

Bir olur çâk-i girîbân ile dâmân-1 hayât (sy. 440) (g.20-1) eteğini yırtar.)

(O hayat devrinin güzeli hançerine el uzatsa hayat aşığın yakasını yırtması gibi aşkından

Sevgilinin gamzesi hançere benzetilir. Yan bakış keskinliği, yaralayıcıllğı, can alması gibi nedenlerle gamze ve hançer benzetmesi yapılır. Sevgilinin bir bakışı âşığı aşkından deliye döndürür. Şair, sevgilinin aşkı karşısında sadece âşı̆̆ın değil hayatın bir bütün olarak etkilendiğini söyler. Âşık nasıl yakasını yırtarsa hayat da eteğini yırtar. Namık Kemal sevgilinin bakışı yerine dudağını kullanır. Sevgilinin dudağının feyzi, bereketi âşığa hayat bağışlar, hayat servetinin sermayesi ise bilinmeyen bir yerdendir:

Feyz'i lâ'lindir eden âşıka ihsân-1 hayât

Gaybdandır bize sermâye-i sâmân-1 hayât (sy. 440)

Galib Bey ve Namık Kemal'in Hz. Musa ve Tur Dağı'na çok sık telmihte bulunduğu bilinmektedir. Gerek sevgili konulu şiirlerde gerekse Tasavvufî şiirlerde bu mazmun her iki şair için de başvurulan temel kaynaktır. "feyz" redifli gazelde de bu mazmundan yararlanılır:

Müncelî oldukça Tûr-i sineden dîdar-1 feyz

Şu'lezâr-1 hasret eyler âlemi envâr-1 feyz (sy. 431) (g. 69-1) doldurur.)

(Feyzin yüzü sinenin Tur dağından parladıkça feyiz nurları alemi hayretin alevleriyle

Namık Kemal tanzir ettiği şiirde sadece feyz üzerinde durur:

Gonce-i hurşîd-i hüsnün kim eder 1zhâr-1 feyz

Bir yemm-i envâr olur her şebnem-i gülzâr-1 feyz (sy. 431) 

olur.)

(Güzellik güneşinin goncası feyzini gösterir, feyzin gül bahçesinin her damlası nurun denizi

Sevgilinin güzelliğinin feyzi, bereketi, 1şığı güneş gibi etkisini gösterir. Bu feyzin her damlası âşık için bir deniz gibidir. Şair sevgilinin güzelliği karşısında âşığın hissiyatını damla ve deniz arasındaki bağla açıklar. Sevgilinin âşık için küçük bir ilgisi bile âşığı kendinden geçirmeye yeter.

Namık Kemal'in 19. yy. şairleri arasında önem verdiği ve şiirlerine nazireler yazdığı diğer şair ise Hersekli Arif Hikmet'tir. "Şeklen eski, fikren yeni manzumeleri ile şöhret-i mahsusa" (Dilmen, 1338: 112) kazanmış bir şairdir. Leskofçalı Galib Bey ve Hersekli Ârif Hikmet Bey, Namık Kemal'in siyasî fikirlerinin oluşmasında ve şiir anlayışının olgunlaşmasında etkili iki isimdir. Ârif Hikmet de eski edebiyat ile yeni edebiyat arasındaki geçişi kolaylaştıran bir geçiş şairidir. Şiirde vezin ve kafiyenin şart olmadığını, şiir ile nazmın birbirinden ayrı şeyler olduğunu, şiirin aslının hayalden ibaret olduğunu, şiirin estetik sebeplerle yazıldığını, şiirde yapılacak değişikliklerin milli kurallar dahilinde olması (Özgül, 2015: 53-54) gerektiğini söyleyen şair, Namık Kemal üzerinde oldukça etkilidir. Namık Kemal de encümen şairleri içerisinde Galib Bey’den sonra en fazla nazireyi onun şiirlerine yazar.

Ârif Hikmet Bey, yaşama biçimi ile iyi bir Müslüman olmak arasında bocalasa da İslam felsefesini şiirlerinde çok iyi işler. Dünyanın geçiciliği, İslam'ın çağa uygun olarak yorumlanışı, modern Müslümandan beklenen hal ve hareketler belli başlı konular arasında yer alır.

Yok kayd-1 mâsivâ dil-i kudsî cenâbda

Olmaz hatâ sahife-i Ümm-ül-kitâbda (sy. 250)

(Kudsî gönülde dünyaya ait bir kayıt yok. Kur'an sayfalarında hata olmaz.)

Dünya varlıklarının geçiciliği ve ebedi devam etmeyeceği tasavvufun üzerinde durduğu bir anlayıştır. Dünyaya ait her şey masiva olarak adlandırılır. Asıl olan dünya malı ile bağlanmak değil, Allah'ı bilmek ve tanımaktır. Hikmet Bey de bu anlayışı ele alır. Namık Kemal de Hikmet Bey'in tasavvufun bu en bilindik anlayışını paylaşır:

Esrâr-1 sun'a bak dil-i hikmet nisâbda

Gör ser nüvişt-i âlemi Ümm-ül-kitâb'da (sy. 249)

(Yaratılış sanatının esrarına bak (ki) hikmet(li) gönül hissesini almış. Âlemin baş mektubunu Kur'an'da gör.)

Allah'ın yarattıklarını hikmet dairesi içerisinde yaratmış olması ve bu hikmeti Kur'an'da anlatması yaratılış sırrının anlaşılmasını sağlar. Hikmet Bey Tasavvufî öğretide masiva olarak adlandırılan dünya malının Kur'an'da olmadığını bu nedenle de Allah katında bir değerinin olmadığını belirtirken Namık Kemal, dünya malının yaratılışındaki hikmeti anlamak ister. $\mathrm{Bu}$ düşünce Tanzimat'ın öncü fikirleri arasında yer alır.

"Bana" redifli gazelinde Hikmet Bey ümit içinde olmadığını, Allah'ın kendisini tüm bu fâni düşüncelerden soyutladığını anlatır. Her şeyden tecrid edilen şair ümit ederek tekrar dünya ile meşgul olmak istemez:

Şimdi nâz eyleyemez saki-i ümmîd bana

Verdi feyyâz-1 ezel neşve-i tecrîd bana. (sy.256) 
Namık Kemal de ümit üzerinde durur. Hikmet Bey'in şiirleri ile Namık Kemal'in nazireleri arasında anlam birliği olmasına rağmen Namık Kemal daha coşkulu bir dil kullanır. Anlam olarak Hikmet Bey'i takip etse de üslup olarak Galib Bey'in etkisi daha baskındır:

Atlas-1 çarh olamaz hil'at-i ümmid bana

Cism-i sadpâre yeter câme-i tecrîd bana (sy. 256)

(Ümit kaftanı bana zamanın örtüsü olamaz. Yüz parça olmuş cismime yalnızlık giysisi yeter.)

Yalnızlık, her şeyden soyutlanmış olmak ve hiçbir şey istememek doygunluğa ulaşmış bir Müslümanın özelliğidir. Ne dünya malı ne de cennet beklentisi olmadan sadece Allah'1 istemek tasavvufî öğretide ulaşılmak istenen son noktadır.

Tecelli sırrı da tasavvufî şiirlerin belli başı konuları arasındadır. Hikmet Bey yine "bana" redifli gazelinde tecelli ve vahdet arasındaki bağı konu edinir:

Râhşiş-i berk-1 tecelli zevk-1 hayrettir bana

Cilve-i esrâr-1 can dîdâr-1 vahdettir bana (sy. 265)

(Tecelli şimşeğinin parıltısı bana hayretin bir zevkidir. Gönül sırlarının cilvesi bana vahdetin yüzüdür.)

Allah'ın yarattığı her şeye tecelli etmesi, isim ve sıfatları ile yaratma işini gerçekleştirmesi Allah'tan başka varlıkların da varlığını kabul etmek gerektiğini düşündürür. Ancak tasavvufta Allah'tan başka hiçbir şey kabul edilmez. Her şeyi tecelli sırrı ile kendinden yaratan Allah'tır. Hikmet Bey bu tecelli sırrına atıf yapıyor. Bu çoklukta o, vahdeti görebilmektedir. Namık Kemal tanzir ettiği şiirinde bu anlamı daha açı ifade eder:

Kesret-i eşyâ ki sûretbend-i vahdettir bana

Pertev-i nûr-i nigeh mir'at-1 hayrettir bana (sy. 264)

(Eşyanın çokluğu bana vahdetin bir görüntüsüdür. Bakışın nurlu ışı̆̆ı bana hayret aynasıdır.)

Namık Kemal de kesret ve vahdet arasındaki ilişkiye odaklanır. Eşyanın çokluğu ondaki vahdet sırrını görmeye engel değildir. Bu sadece çokluk içindeki tekliğin görülmesi için bir araçtır. Bakışın nurlu parıltısı bu sırrın anlaşılması için hayret aynası gibidir. Bu gazelde Namık Kemal gerek üslup gerek anlam olarak Hikmet Bey'i takip eder.

"Bulunmaya" redifli gazelde sade bir dil ve anlatım dikkat çeker:

Bir râha âzim ol ki habîrî bulunmaya

Bir mülke var ki şâh u veziri bulunmaya (sy. 276) bulunmasin.)

(Bir yola niyet et ki ondan haberi olan bulunmasın, bir yere var ki şâhı ve veziri

Hikmet Bey, tasavvuf anlayışını gazellerinde açık ve anlaşılır bir dille ifade eder. Divan şairlerinden ayrılan yönü bu noktada ortaya çıkmaktadır. Allah yolunun yolcusu, dünya ile bütün irtibatını keserek hedefe kitlenir. Vardığ 1 yerde O'ndan başka kimse yoktur. Bu, kesretten vahdete giden bir yoldur. Namık Kemal'in şiirinde yol değil, varış esas alınır:

Bir şuha bende ol ki esîri bulunmaya

Bir feyze talib ol ki habîri bulunmaya (sy. 275)

(Bir sevgiliye kul ol ki esiri bulunmasın, Bir feyze talip ol ki haberi olmasın.) 
Âşık ve sevgili de divan şiirinde olduğu gibi Hikmet Bey için de belli başlı konular arasındadır. "âftâb" redifli şiirde sevgiliyi şöyle anlatır:

Şevk-i rûyin olsa aksendâz-1 sûy-i âftâb

Kulzüm-i envâr olur girdâb-1 cûy-i âftâb (sy. 280) denizi olur.)

(Güzelliğinin semtine çarpıp duran yüzünün şevki olsa, güzelliğinin akıcı girdabı nurun

Sevgilinin güzelliği karşısında âşı, büyük bir hayranlık duyar. Sevgilinin güzelliğinin yansıması, ışı̆̆ı nur gibi bir denizi meydana getirir. Sevgilinin bu güzelliği aynı zamanda âşık için bir girdap gibidir. Önemli olan da bu girdaba kapılmadan ondaki nuru görebilmektir. Namık Kemal de benzer bir söylemde bulunur:

Şem'-i hüsnün olsa feyefzâ-yi sû-yi âftâb

Fer verir mişkât-1 arşa reng-i rûy-i âftâb (sy. 279)

(Güzelliğin çırası güzelliği, güzelliğinin 1şık saçan bir (nesnesi) olsa, Güzellik yüzünün rengi arşın lambasına (güneşe) parlaklık verir.)

Şair özellikle sevgili ile ilgili şiirlerinde oldukça başarılıdır. Namık Kemal'in özgün benzetmeleri ve kullanımı, üslubu bu şiirlerde daha net ortaya çıkar. Sevgilinin yüzünün renginin güneşe bile parlaklık vermesi yeni bir kullanımdır.

Ârif Hikmet Bey, sevgiliyi güzelliğinin ışığı ile tasvir eder. Sevgilinin 1şı̆̆ı̀ın, parıltısının âş1k üzerindeki etkisi ortak bir tema olarak görülür. "mehtâb" redifli gazelinde:

Fürûg-i rûyin olsa dâğsûz-i sîne-i mehtâb

Yanar hayt-1 şuâmdan dil-i bî kîne-i mehtâb (sy. 280) tutuşur.)

(Yüzünün 1şığı, ayın sinesinin yarası olsa, ayın kin tutmayan gönlü ışığımın bağı ile yanar,

Ârif Hikmet Bey şiirlerinde cümle yapısını farklı bir cümle yapısı ile kurar ve şiirlerinde bu yapıyı sürdürür. Devrik cümle yapısını, başta yüklemi vurgulayarak oluşturur. Bu cümle yapısı anlamı muğlak hale getirirken ritim sağlamak ve okurun şiire odaklanmasının sağlanması bakımından farklı bir özelliğe sahiptir. Namık Kemal, üslup olarak daha çok Galib Bey'i takip ettiği için Ârif Bey'in bu özelliğinden bazı şiirlerinde yararlanır. Bu şiire yazdığı nazirede de;

Olunca aks-i rûyin şu'le cûş-i sîne-i mehtâb

Yümn-i nûr oldu âb-1 cevher-i âyine-i mehtâb (sy. 280)

Ârif Bey’in üslubundan çok Galib Bey’in söyleyiş tarzına yakındır. Sevgilinin yüzünün aksi ayın sinesini coşturan bir ışık olunca ayın aynasının cevherinin suyu nurun, ş̧ı̆ı̆ın çıkış noktası, merkezi olur. Anlam olarak Ârif Hikmet Bey'in gazeline oldukça yakındır.

Başka bir gazellerde de yine sevgilinin 1şığı üzerinde durulur.

Tâbiş-i hüsnünle dâğ-1 sîne rûşendir bu şeb

Dûdmân-1 şu'le-i can sûziş efgendir bu şeb (sy. 281) yakıcıdır.)

(Bu akşam güzelliğinin parıltısı ile gönlümün yarası 1şık saçar, Can 1şığının ailesi de

Tab'ımdadır hazîne-i hikmet resân-1 gayb 
Olsam nola cihana leâli feşân-1 gayb (sy. 283) olur.)

(Gayba gidenler ve hikmet hazinesi parıltımdandır, dünyaya gaybın inciler saçanı olsam ne

Namık Kemal de benzer bir hayal dünyası oluşturur:

Berk u şemşîrinle bezm-i sîne rûşendir bu şeb

Şu'le-i seyyâle mişkâtımda revgandır bu şeb (sy. 281)

(Bu akşam kılıç ve şimşeğinle gönül âlemi 1şıklıdır, akıp giden ışık üzerimde bir rahatlıktır.)

Lâ'lindendir define-i cevher feşân-1 gayb

Ey her kelâmı dürr-i yümm-i bîkerân-1 gayb (sy. 282) incisi olan)

(Gaybın cevher definesi saçması senin dudağındandır. Ey her sözü gaybın sabahsız bereket

Namık Kemal'in tanzir ettiği "şeb" redifli gazelde, hayali Ârif Bey’den almış olmasına rağmen yeni bir ifade ya da bir özgünlük yakalayamadığını da belirtmek gerekiyor. "gayb" redifli şiirde ise neredeyse aynı kelimelerle bir taklit oluşturur. Bu şiirler Namık Kemal'in encümende okumak için yazdığ 1 şiirler olmalıdır. Ârif Hikmet Bey'in şiirlerini de tanzir edebilme yeteneğinin bir göstergesi olarak alınabilir.

Âşığın aşkından dolayı acı çekmesi, inlemesi sevgilinin aşkı nedeniyledir:

Zannetme kim hevâdan olur nâlekâr mevc

Râz-1 hurûş-i aşk1 eder âşikâr mevc (sy. 283)

(Âşığın inlemelerini isteyerek yaptığını zannetme, aşk coşkusunun mimarı bu inleme dalgasının sebebidir.)

Namık Kemal de sevgilinin sebep olduğu aşk coşkusunu Hikmet Bey’in gazeline benzer bir tarzda ele alır:

İzhâr edince cevher-i şemşîr-i yâr mevc

Hûnumda haşre dek görünür bîşümâr mevc (sy. 283)

(Sevgilinin kılıcının cevheri dalgayı gösterince, kanımda sayısız dalga haşre kadar görünür.)

Hikmet Bey, sevgili ile ilgili yazdığ 1 şiirlerden başka Tasavvufî şiirler de yazar. Tecelli, vahdet, ihlas gibi konular şairin sıklıkla üzerinde durduğu konular arasındadır. "murâd" redifli gazelinde tecelli üzerinde durur:

İntişâr-1 feyzdir nûr-i tecellâdan murâd

İktibâs-1 şu'ledir şem'-i ârâdan murâd (sy. 286)

(Tecellinin nurundan kastedilen feyzin yayılmasıdır. Süslenmiş kandilden kasıt da 1şı̆̆ın ödünç alınmasıdır.)

Allah'ın varlık âlemine tecelli etmesi yaratılışın bir gereğidir. Allah'ın tecelli ettiği varlıklar, bu tecelli ile feyz ve bereket bulur. Şair, bu tecelli ve feyz arasındaki ilişkiyi kandil ve kandilin 1şı̆̆ arasındaki bağa benzetir. Kandilin 1şığı ulaştığı her yeri aydınlatır, Allah'ın tecelli ettiği her yer de bereket bulur. Namık Kemal bu şiire yazdığı tanzirinde tevhid sırrını açıklar:

Neş'e-i tevhîddir nüh tâs-1 mînâdan murâd 
Hâlet-i zevk u safâdır câm-1 sahbâdan murâd (sy. 286)

(Dokuz sırça tastan kasıt tevhit neşesidir. Sabah kadehinden kasıt da zevk ve sefa hâlidir.)

Şair varlık âleminin yaratılması ve çeşitlendirilmesinin asıl amacının birliği göstermek olduğunu belirtir. Kâinatın bir düzen içinde kurulması ve varlığını devam ettirmesi, bu kadar çeşitlilikte bir karmaşanın yaşanmaması Allah'ın birliğinin bir göstergesidir. Bu, kadehin istenmesinin asıl nedeni zevk ve sefa istendiğinin bir işaretidir. Asıl amaç kadeh değil, zevk ve sefayı vurgulamaktır.

Vücudun son bulması, ölüm konusu insanlar arasında belli başlı fikir ayrılıklarından biridir. Bazı inançlarda öldükten sonra yaşamın olmadığına inanması, bazı inançlarda ise kutsal kitaplardakinden farklı bir hayatın öngörülmesi bu farklılıklardan bazılarıdır. Kutsal kitaplarda ise ölüm ve ölümden sonra ahiret hayatının varlığı ortaktır. Vücud ölse de ruh yaşamaya devam eder. Sadece başka bir âleme geçiş yapar. Hikmet Bey bu konuya "vücud" redifli gazelinde açıklık getirir:

Ne kadar tefrika bend olsa da ifnây-1 vücûd

Zâil olmaz yine mâhiyyet-i sîmâ-yi vücud (sy. 292) yok olmaz.)

(Vücudun son bulması, her ne kadar ayrılık meydana getirse de vücudun yüzünün mahiyeti

Namık Kemal'in şiirinde ise aşk ile ölüm arasında bir ilişki kurar:

Eylemiştim eser-i aşk ile ifnâ-yi vücûd

Olmadan mülk-i fenâ vâyepezîrâ-yi vücûd (sy.292)

(Yokluk âlemi vücudu kabul etmeden, aşkın eseri ile vücudu öldürmüştüm.)

Ölmeden önce ölmek olarak açıklanan nefsin isteklerinden vazgeçerek Allah aşkını bulmak anlayışını, Namık Kemal yeni bir ifade ile dile getirir. Ölüm, bu dünyadan gitmek, bu dünyadan yok olmak, başka âleme geçmek anlamında alındığında vücudun fâni mülkler arasına girmesi şaire has yeni bir söyleyiştir. Bu şiirin Namık Kemal'in Hikmet Bey'in şiirlerine yazdığı nazireler arasında en başarılılarından biri olduğunu söylemek istiyoruz.

İnsanın neşe ve keder arasında bulunması yaratılıştan gelen bir özelliktir. İkisi arasındaki dengeyi kurmak insanın bu dünyadaki imtihanının bir neticesidir. Hikmet Bey, bu dengeyi şöyle açılar:

Bir neş'e komuş Hikmet-i Hak tıynetimizde

Âsâr-1 safâ var dil-i pür mihnetimizde (sy. 295) eserleri var.)

(Allah hikmetiyle yaratılışımıza neşe koymuş, Çok zahmet çeken gönlümüzde sefanın

Namık Kemal neşe ve keder arasındaki dengeyi Hz. Ali örneği ile açıklar:

Vardır eser-i hâk-i Necef tıynetimizde

Hep sîret-i Hayder görünür suretimizde (sy. 295)

(Yaratılışımızda Necef toprağının eseri vardır, suretimizde Hayder (Hz. Ali)'in yüzü görünür.)

Bazı tarihçilere göre Hz. Ali'nin mezarı Irak'ta bulunan Necef'tedir. Namık Kemal'in Şiilikle ilgili bir irtibatı olmamasına rağmen bir süre Bektaşi dergâhlarına devam eden Hikmet Bey'den etkilenerek bu şiiri yazdığı söylenebilir.

\section{Turkish Studies - Language and Literature}

Volume 14 Issue 4, 2019 
Gerek yaratılış sırrının anlaşılmasında gerekse İlahî tecellinin anlaşılmasında kalp önemli bir görev üstlenir. Mânâ âleminin anlaşılması kalbin o âlemi anlayıp açıklaması ile gerçekleşir. Manevi tecellilerin anlaşılması için de kalbin istenen olgunluğa erişmesi gerekir. Kalbin bu öğretici ve kemale ermesi ile mânâ âleminin kapılarının açılacağı düşüncesini Hikmet Bey "kalp ile" redifli gazelinde ele alır:

Ârif-i ma'nâya tevhidiz meâl-i kalb ile

Dâniş âmûz-i füzûyâtız kemâl-i kalb ile (sy. 296)

Namık Kemal'in tanzir ettiği gazelde kaza ve kadere atıfta bulunulur:

Şerh ü tafsil-i kazâ birdir meâl-i kalb ile

Ma'ni-i Ümmülkitabız biz kemâl-i kalb ile (sy. 296)

(Kalbin açıklaması ile kaza ve kader birdir, biz olgun bir kalp ile Kur'an'ın bir engelleyicisiyiz.)

Allah, Kur'an'da her şeyi anlatmıştır. Ancak insan onu okuyup öğrendikçe onu kendi ilmi ile anlamlandırır. Bu sonsuz bir anlam ve manaya sahip Kur'an'ın diğer anlamlarının anlaşılmasında bir engeldir. Kaza ve kader de kalp ile açıklanabilirse birdir. Birbirinden ayrı şeyler değildir. Namık Kemal, kalp olgunluğunun olumsuz tarafina işaret eder.

Sevgiliden duyulan gam ve kederin âşık için istenilen bir durum olduğu divan şiirinin norm haline gelen bir düşüncedir. Farklı şekillerde ifade edilse de temel anlam değişmez. Hikmet Bey'in;

Neş'e-i şâdî verir gam meşreb-i rindâneye

Bak sâfâ-yi handerîz-i girye-i mestâneye (sy. 300)

matlalı şiirinde bu anlam vurgulanır. Rind meşrep olan için gam mutluluk verir. Namık Kemal tanzir ettiği bu gazelde sadece gam ve keder üzerinde durur:

Geldi sahrâ-yi âdemden dil bu mihnethâneye

Mürg-i hasrettir gezer viraneden viraneye (sy. 300)

(Gönül bu acı çekilen eve âdem meydanından geldi, hasret kuşu gibi viraneden viraneye gezer.)

Namık Kemal'in Hikmet Bey'den etkilendiği önemli bir husus da dildir. Hikmet Bey'e yazdığı nazirelere toplu olarak baktığımızda bu şiirdeki gibi sade bir dilin kullanılmaya başladığını görürüz. İlk nazireler ile son nazireler arasında dil bakımından görülen bu sadelikte Hikmet Bey'in katkısı da göz ardı edilemez.

Keder ve üzüntü ile ilgili bir diğer şiir de "kadeh" redifli gazeldir:

Dâğ-1 hicrânınla hunin lâledir gûyâ kadeh

Sine-i pür sûzuma hemnâledir gûyâ kadeh (sy.304) inleyendir.)

(Hicran yarasıyla kırmızı lale güya kadehtir, kadeh çok acı çeken sinemle birlikte ağlayan

Bu şiirde Hikmet Bey, divan şiirinin klasik mazmunlarını kullanır. Lale ve kadeh, hicran yarası divan şiirinin en çok kullanılan mazmunları arasındadır. Namık Kemal'in şiirinde de benzer bir kullanım söz konusudur:

Bülbül-i câna medâr-1 naledir gûyâ kadeh 
Nev şüküfte gonca-i pür jâledir gûyâ kadeh (sy.304)

(Can bülbülüne güya kadeh ağlayıp inleme sebebidir, kadeh güya yeni açmış gonca yaprağında çiğ tanesi gibidir.)

"rûh" redifli gazelde Hikmet Bey, ruhu tanımlar:

Olmasa rûh-i izâfî cevher-i minâ-yi rûh

Neşvebahş-1 hayret olmazdı dile sahbâ-yi rûh (sy. 305)

(Ruhun sırça cevheri izafi olmasa, ruhun sabahı gönle hayret neşesi veremezdi.)

Ruhun varlığı, izafidir. Vücuda yön veren, harekete geçiren, cansız vücudu canlandıran ruhun bu özelliği izafi olan her şeyin anlaşılmasına da fayda sağlar. Ruhun varlığı bilindiğine göre her duygu ve düşünce de ruh gibi vardır ancak izafidir. Namık Kemal aynı redifli gazelinde yine ruhu tanımlar.

Hayret efzâ-yi cihandır tavr-1 feyz ârâ-yi rûh

Kim olur mevt-i irâdî bâis-i ihyâ-yi ruh (sy. 305)

Hayret; ruhun süsü, feyiz hali, ruh ışığının dünyasıdır ki ruhun canlanmasının sebebi de hayrettir. Ruh ve hayret birbirini harekete geçiren iki unsurdur. Allah'ın tecelli ederek yarattığı her şeye karşı duyulan hayret ruhun canlanmasına ve ebedi ölümden kurtulmasına araç olur. Bilinçli bir ruh, rıza-yı İlahî’yi kazanacağı için de ölümden kurtulur, neşeyi bulur.

Sevgilinin gamzesi divan şiirinde birçok şekilde kullanılır. Divan şairleri gamzeyi sevgilinin yanağında oluşan çukurdan çok sevgilinin âşığı baştan çıkaran anlamlı, hüzünlü bakışına benzetir. Gamze mazmununu Hikmet Bey'de bu anlamda kullanır:

Nerdendir âşıka dâim itâb-1 gamze-i şûh

Serâser olmada âlem harâb-1 gamze-i şûh (sy. 309) harap etti.)

(Sevgilinin gamzesinin aşığı helak ediciliği nerdendir, sevgilinin gamzesi baştan başa âlemi

Namık Kemal ise gazelinde sevgilinin gamzesinin 1zdırabının kazayı bile etkileyecek derecede olduğunu ancak bunun şiirde ifade edilmesinin imkânsız olduğunu söyler:

Kazâya ra'şi verir 1ztırâb-1 gamze-i şûh

Bakılsa nazma yok çevre tâb-1 gamze-i şûh (sy. 309)

"Şuh" redifli gazel Fehim tarafından yazılmış olup Hikmet Efendi ve Namık Kemal bu gazeli tanzir ederler. Fehim ve Hikmet Bey'in gazelleri ortak bir anlam içerirken Namık Kemal'in gazeli gerek söyleyiş gerekse anlam olarak daha zayıftır.

Gönül ve aşk arasındaki ilişki Hz. Musa'nın Tur Dă̆ı'nda Allah ile görüşmesi anına atıf yapılarak da ifade edilir. Bu anlamı güçlendiren bir kullanımdır. Hikmet Bey'in "gönül” redifli gazeli bu anı hatırlatmaktadır:

Mahrem-i esrâr-1 bezm-i lenterâni'dir gönül

Mûsi-i imran-i aşkın tercemânidir gönül (sy. 326)

(Gönül, lenterâni (beni göremezsin) zamanının sırlarının en gizlisidir, gönül aşkın Musa'sının tercümanıdır.) 
Hz. Musa ve Tur Dağı hadisesi Namık Kemal ve Galib Bey için de farklı bir öneme sahiptir. İnsan ve Allah arasındaki aşkı, birleşmeyi temsil eden bu hadise bu şairlerin dikkatini çeker. Namık Kemal bu gazele yazdığı nazirede insan ve Allah arasındaki buluşmanın ikinci örneği olan miraç hadisesinden bahseder. Hz. Muhammed miraçta Allah'la görür ve onunla görüşür:

Güftü-gû perdâz-1 feyz-i bîzebânîdir gönül

Bezm-i mi'rac-1 visâlin râzdânidir gönül (sy. 326) olandir.)

(Gönül zebanisiz feyzin dedikodusunun çıkartandır, kavuşma miracı âleminin sırrına sahip

Gönlü şairler insandan ayrı, İlahî tecelliye mazhar olan bir varlık olarak ele alır. Bu nedenle de onun sahip olduğu aşk duygusu da bulunduğu yer nedeniyle bir kudsiyet gösterir.

Felekten şikâyet ve feleğin adaletsizliğinden dert yanma divan şairlerinin sıklıkla başvurduğu bir temadır. Hikmet Bey feleğin adaletsizliğinden şikâyet eder. Acı verdiği kadar adaletli davransa dünyanın feyz ve bereketi feleğin olurdu, anlamını vurgular:

Olaydı dâd-1 felek renciş-i sitâd-1 kadar

Bulurdu feyz-i tabîi cihan murâdı kadar (sy. 369) bulurdu.)

(Felek eziyet verdiği kadar adaletli olsaydı, istediği kadar dünyanın feyz ve bereketini

Namık Kemal, Hikmet Bey'in bu gazelini tanzir ederken gerek anlamı gerekse söyleyişi kendine has bir üslupla dile getirir. Felek gibi muallakta kalan bir kelime yerine devlet ehlini kullanır. $\mathrm{Bu}$ şiir Namık Kemal'in yeni şiirlerine anlam olarak daha yakındır. Sosyal bir eleştiri olan şiirin ilk matla beyti şu şekildedir:

Revâc-1 ilm ü kemâl olsa ger kesâdı kadar

Ererdi devlete ehl-i hüner murâdı kadar (sy. 368) (makam) ererdi.)

(Eğer eksikliği kadar ilim ve kemalin revacına erseydi hüner ehli istediği kadar devlete

Gönül ve can kelimeleri divan şiirinde madde ve mana ayrımına işaret eder. Gönül ruh, can ise kalp ile ilişkilidir. Sevgilinin verdiği acı, üzüntü, keder âşı̆̆ın gönlünde sürekli taze kalır. Ancak âşık bu cefadan da memnundur, onu şevke getirir:

Hânmânsûz-i kazâ dâğ-1 fürûzânımdır

Şu'le-i berk-1 belâ şevk-1 dil ü cânımdır (sy. 392)

(Kaza evinin ateşi yaramın 1şığıdır, bela şimşeğinin 1şığı gönül ve can şevkimdir.)

Âşığın sevgiliden çektiği acı, bela sadece kendisinin yaşadığı bir duygudur. Âşık, bu acıdan doğan gözyaşının kimse tarafından görülmesini, bilinmesini istemez. Namık Kemal, sevgilinin acısını, üzüntüsünü divan şiirine ait mazmunlarla anlatır. Ancak burada mazmunların kullanımında bir yeniliğe gider. Divan şiirinde sevgilinin kirpiği söz konusu iken şair, kendi kirpiğinden bahseder:

Dile mîzâb-ı belâ kim ser-i müjgânımdır

Mevc-i seylâb-1 âdem girye-i pinhanımdır (sy. 392)

(Gönle belanın oluğu kirpiğimin başıdır, insan selinin dalgası gizli gözyaşımdır.) 
Divan şiirinde sevgili için kullanılan mazmunların âşık için kullanılmaya başlanması akımını Hikmet Bey de devam ettirir. "olur" redifli gazelinde;

Fikr-i kaddinle dîde garkab-1 hûn olur

Müjgân gözümde serv-i siyahtâb-1 hûn olur (sy. 399)

(Boyunun düşüncesi ile gözüm kan dolar, kirpik gözümde kanın siyah 1şıklı servi olur.)

kirpiği yine âşık için kullanır. Sevgilinin boyu da âşığı etkileyen bir çekiciliğe sahiptir. Onun uzun boyu karşısında âşığın gözleri kan dolar ve kirpikler de kanın ışığını saçar. Namık Kemal ise şiirinde sevgilinin açtığı yarayı konu edinir:

Sînem ki zahm-1 aşk ile garkab-1 hûn olur

Her mû tenimde lâle-i mîzâb-1 hûn olur (sy. 398)

(Gönlüm aşk yarası ile kanla dolar, tenimdeki her kıl kan oluğunun lalesi olur.)

Aşk, âşığın bedeninde de etkilidir. Aşkın vücutta açtığı yaralar kanla dolar ve bu kanlar kılları bir laleye dönüştürür. Sevgilinin aşkıyla âşık acı çekse de yarayı dolduran kan bile kılları laleye çevirir.

Sevgilinin yüz güzelliği ile ilgili birçok benzetme yapılır. Divan şiirinde en fazla konu edinilen sevgiliye ait değerlerin başında onun bu güzelliği gelir. Hikmet Bey "behişt” (cennet) redifli gazelinde sevgilinin yüz güzelliğini en uç noktada tasvir eder:

Şevk-1 rûyin ki ola şem-i şebistân-1 behişt

Can verir şu'le-i dîdârına sükkân-1 behişt (sy. 411) can verir.)

(Yüzünün şevki cennetin yatak odasının akşamıdır, Cennet sakinlerinin yüzlerinin 1şığına

Namık Kemal, Hikmet Bey'in bu şiirini hem üslup hem de anlam olarak tanzir eder:

Berk-1 âhım ki olur zîb-i hiyâbân-1 behişt

Nâr-1 nîrâna döner her gül-i handân-1 behişt (sy. 411)

(Âhımın şimşeği cennet yolunun süsü olur, cennet bahçesinin her gülü yanan ateşe döner.)

Âşı̆̆ın ahı o kadar derin ve içtendir ki cennet bahçesinin gülleri bile o acıdan yanar ve küle dönüşür. Bu gazelde Namık Kemal hem Hikmet Bey'den hem de Galib Bey'den aldığı üslubu birleștirir.

Hikmet Bey'in tasavvufî konularda yazdığı şiirler de azımsanmayacak kadar çoktur. "sükût" redifli gazelinde sükût ve söyleme üzerinde durur:

Mâni'-i izhar şükr-i lûtf-i yezdan'dır sükût

Ben demem şâyeste-i erbâb-1 ikandır sükût (sy. 412) demem.)

(Sükût, görünenin engellenmesi, Allah'ın lütfunun şükrüdür, Ben sükûta âriflere yaraşır

Konuşabilme, Allah'ın yarattıkları içerisinde sadece insana lütfettiği bir nimettir. Bu nimetin şükrü de sükût edebilmektir. Hikmet Bey, bu şükrün sadece ârifler için değil konuşma yeteneğine sahip herkes için söz konusu olduğunu söyler. Namık Kemal de tanzir ettiği şiirinde sükût üzerinde durur:

Râzdân-1 halvet-i mi’râc-1 cânındır sükût 
Meclis ârâ bir nedîm-i kurb-i Yezdan'dır sükût (sy. 412) süsüdür.)

(Sükût, gönlün sırlı miracının kavuşmasıdır, Allah'ın yakın sohbet arkadaşının meclisteki

Miraç hadisesi ve Tur Dağı hadisesinin şairler için önemli ve farklı bir değere sahip olduğunu belirtmiştir. Dünyadayken Allah'la görüşülen iki hadise olarak bilinen bu mucizeler şiirlerde farklı şekillerde ele alınır. Allah'la buluşan Hz. Peygamberin sohbet anında sessiz kalması, sükût etmesi, bir edep gereğidir. Şair bu edebi bir süs olarak görür. Namık Kemal bu şiirde Hikmet Bey'in üslubunu taklit eder. Anlam olarak Namık Kemal'in sükût için miraç hadisesine telmihte bulunması şiirin anlam gücünü kuvvetlendirir.

Hikmet Bey "garaz" redifli şiirinde garazın, amaç ve niyet anlamı üzerinde durur:

Bahr ü berden gevher-i yekdâne-i dildir garaz

Bilmeyenler zanneder deryâ vü sahildir garaz (sy. 415) zanneder.)

(Garaz, gönlün kara ve denizdeki tek cevheridir, bilmeyenler garazın deniz ve sahil olduğunu

Amaç, kara ve denizde, bütün yeryüzünde insanın sahip olduğu tek değeridir. Amacı olmayan insanın yeryüzünde sahip olabileceği başka bir değeri de yoktur. Ancak bilmeyenler için amaç, deniz ve sahil gibi biri varsa diğeri vardır, bağlamında ele alınacak bir histir. Denizin olmadığ yerde sahil olmayacağ 1 için sebep sonuç ilişkisi içerisinde bir durum söz konusudur. Şaire göre ise amaç, sebep sonuç ilişkisi içerisinde değerlendirilebilecek bir şey değildir. Namık Kemal de garazı bu anlamiyla ele alır:

Âlem-i icâddan insân-1 kâmildir garaz

Hep şüunât-1 kazâdan suret-i dildir garaz (sy. 415)

(Garaz, yaratılış zamanından kâmil insandır, kazanın hallerinden gönlün suretidir.)

Şair, garazı, amacı olan insanı kâmil insan olarak tanımlar. Kaderin gerçekleşmesi olarak tanımlanan kazanın olması gönlün bir yansımasıdır. Amaç sonuç ilişkisi olarak değerlendirilebilecek bu durum insanın yaşadığı olaylardaki İlahî sırrın anlaşılması için bir gerekliliktir.

Garaz gibi düşünce üzerinde de duran Hikmet Bey, düşünceyi kudsî bir güç olarak tanımlar:

Kuvve-i kudsiyyedir sernâme-i telkinimiz

Sâye-i feyz-i âli'dir mâye-i temkinimiz (sy.419)

(Düşüncemizin önsözü kudsi bir güçtür, vakarımızın mayası yüce bir feyzin gölgesidir.)

Düşünerek hareket etme, söylediklerimizin bir fikir içermesi ve bunu başka insanlara verebilme düşüncesi kudsi bir güçtür. Şairlerin topluma söyleyecek sözlerinin olması da bu gücün bir göstergesidir. Vakar, ağırbaşlılık da insana verilen bir bereket, nimettir. Namık Kemal ise tevhid üzerinde durur:

Sirr-1 vahdettir meâl-i mezheb ü âyinimiz

Hükm-i tevhîd-i İlâhîdir esâs-1 dinimiz (sy.419) hükmüdür.)

(İbadetimiz ve inancımızın açıklaması vahdet sırrıdır, dinimizin esası Allah'ın tevhid

İslam dininin esası ve temeli Allah'ın var ve bir oluşudur. Kelime-i tevhid ve kelime-i şehadet ile İslam dininin kabulü söz konusudur. Namık Kemal de dinin bu en temel anlayışını ifade 
eder. Hikmet Bey'in sahip olduklarının Allah'tan olduğunu söylemesi ile tevhid inanc1 örtüşmektedir. Namık Kemal, gazeldeki ahenk ve ses unsurlarını Hikmet Bey’den alır.

Hikmet Bey'in aşk ve sevgili konulu gazellerinde divan şiiri anlayışının devam ettirildiğini ve kendisinden önceki şairler kadar başarılı şiirler yazdığını söylemek mümkündür:

Hadîka-i Hat-1 müşgîn-i yâre dek gideriz

Nesîm-i gülşen-i aşkız bahâre dek gideriz (sy.420) gideriz.)

(Sevgilinin misk kokulu bahçesine kadar gideriz, Aşk gül bahçesinin rüzgârıyız bahara kadar

Sevgilinin bulunduğu düşünülen bahçe ve bu bahçede esen rüzgâr mekân olarak âşığın bulunmak istediği ve sürekli hayalini kurduğu bir yerdir. Namık Kemal bu şiire yazdığı tanzirinde de sevgilinin mekânıyla ilgili bir hayal kurulur:

Hevâ-yi aşk ile kûy-i nigâre dek gideriz

Yem-i cünuna ki düştük kenâre dek gideriz (sy. 420) gideriz.)

(Aşk havası ile sevgilinin mahallesine kadar gideriz, delilik haline düştük sonuna kadar

Aşkın âşı̆ğ deliye çevirmesi, Mecnun'a döndürmesi aşkta bir sondur. Mecnun, Leylâ'nın aşkıyla deliye döndükten sonra ona kavuşsa da artık o maddi aşktan geçmiş, İlâhi aşka düşmüştür. Şair, aşk yoluna girdikten sonra dönüşünün olmadığını ve İlahî aşka kadar giden bir süreç olduğunu vurgular.

Dünya malından vaz geçerek İlahî aşka ulaşmanın temel amaç olarak kabul edildiği dergâhlarda bu amaca ulaşabilmenin gerekleri öğretilir. Hikmet Bey, belli bir tarikata mensup olmasa da devrin bilinen tarikatları ile zaman zaman iç içedir. Bu anlayışı gazellerinde de görmekteyiz:

Hırka ber dûş-i ferağız târik-i seccadeyiz

Nâmurâd-1 âlemiz ammâ mürîd-i bâbeyiz (sy. 423)

(Seccade yolundayız, hırkası omzundan düşmüş kimseleriz, âlemin isteksiz kimseleriyiz ama kapının müritleriyiz.)

Hırka, dergâh ehlinin kullandığı aynı zamanda belli bir yolun müridi olduğunu gösteren bir giysidir. Bu hırkayı giyen dünya malına karşı isteksizdir, her şeye karşı gına gösterir ancak talep ettiği İlahî aşkla beraber Allah'ın takdir ettiği nimetlerdir. Namık Kemal ise mürid olmanın şartlarını belirler:

Dil şikest-i câm-1 mey sûzefgen-i seccadeyiz

Ne murâd ârâ-yi zühdüz ne mürid-i bâdeyiz (sy. 423)

(Gönül kırık içki kadehi, yanıcı seccadeyiz ne zühd isteyen süsüz ne de kadeh müridiyiz.)

Müritlik boş bir istek ve arzu ya da gösteriş için yapılacak bir şey değildir. Âşığın gönlü İlahî aşka henüz ulaşamamış kırık bir gönüldür. Bu nedenle de bu aşka ulaşabilmek için o yolda çaba sarf etmeye devam eder. Gerek Hikmet Bey'in gerekse Namık Kemal'in bu gazelleri Tasavvufî 1stılahın gereklerini ve felsefesini anlatması bakımından ağır bir dil ve anlam yükü söz konusudur.

Hikmet Bey'in divan şiir geleneğini sürdüren ve bu geleneğe bağlanan gazellerden biri de "âhımız" redifli gazeldir:

Nefha-i canperver-i bâğ-1 cinandır âhımız 
Bülbül-i aşkız nesîm-i lamekândır âhımız (sy. 425) rüzgârdır.)

(Âhımız delilik bahçesinin can koruyan nefesidir; aşkın bülbülüyüz, âhımız mekânsız

Âh, âşığın aşkının somut bir göstergesidir. Bazen ayrılıktan bazen acıdan kaynaklı âh, anlam olarak âşığın hayatta olduğunu ve hâlâ sevgilinin aşkı ile yandığını gösterir. Hikmet Bey, âşığın bu âhını yeni bir benzetme ile mekânız bir rüzgâra benzetir. Divan şiirinde sevgilinin bahçesine giden âh rüzgârı, Hikmet Bey de mekânını kaybeder. Bahçe aynı bahçe bülbül aynı bülbüldür ancak âh mekânı kaybetmiştir. Namık Kemal'in aynı redifli gazelinde ise;

Dûdman zîb-i fürûg-i sûz-i candır âhımız

Mahv-i aşkız nûr-i çeşm-i kudsiyandır âhımız (sy. 424)

(Âhımız canın yakıcı 1şık saçan süsünün ailesiyiz. Aşkın mahvettiği kimseleriz, âhımız kudsîlerin gözünün nurudur.)

mısralarında âşıkların ortak hissiyatını gösteren "âh"1n onları aynı ailenin birer üyesi haline getirdiğini söyler. $\mathrm{Bu}$ sesi çıkartan âşıklar, aşktan mahvolmuş ve bu yolda mertebe kat etmiş kudsîlerin de beğenisini, takdirini kazandırmıştır.

Divan şiirinde en sık kullanılan kelimelerden biri feyz kelimesidir. Bolluk, bereket, ilim, irfan gibi birçok olumlu anlama gelen feyz, istenilen, elde edilmek istenen anlamıyla şiirlerde yer alır:

Hilye-i dâniş olur zîbiş-i nev kâle-i feyz

Yoksa revnak veremez câhile pergâle-i feyz (sy. 430) veremez.)

(Feyz sözü yeniden artarsa âriflerin süsü olur; yoksa feyzin parçası câhil kişiye parlaklık

Bereket, bereketin lütfu âriflerin sıkça dile getirdiği ve şükre vesile olan bir durumdur. $\mathrm{Bu}$ feyz ve bereketin tekrar dile getirilmesi ârifler için bir güzelliktir. Zaman içerisinde unutulan, ihmal edilen bu alışkanlığın tekrar kazanılması ârifler için gereklidir. Yoksa bu feyzin câhiller tarafindan anlaşılması ve şükredilmesi imkansızdır. Feyzi ârifler idrâk eder ve câhillere anlatarak idrak etmelerini sağlarlar.

Hâl-i rûyin ki olur dâğ-1 dil-i lâle-i feyz

Mihri lerzende eder şa'şaa-i jale-i feyz (sy. 430)

(Yüzünün hâli feyz lâlesinin gönül yarası olur; feyz damlacığının gösterişi güneşi titretir.)

Sevgilinin yüz güzelliği âşık için bir feyz, berekettir. Onun âşıkta bıraktığı iz aşk yarasıdır. Ancak bu feyz güneşi titreten bir büyüklüğe sahiptir. Hikmet Bey, feyzin idari ile birlikte anlam kazandığını söylemesine karşın Namık Kemal feyzin büyüklüğünü konu edinir. Hikmet Bey’in aynı redifli diğer gazelinde ise;

Eşg sanma dideden rîzan olur enhâr-1 feyz

Dildedir cûş ü hürûş-i bahr-1 gevherbâr-1 feyz (sy. 431)

(Feyzin ırmaklarını gözyaşı sanma (feyz) gözden akar; feyzin cevher taşıyan denizinin coşması gönüldedir.) 
Feyz, âşı̆̆ın gözyaşından ibaret değildir, feyzin asıl yeri gönüldür. Orada coşup taşan feyz, gözlerden akar. Feyzin somut görünümünden çok soyut görünümü esastır. Namık Kemal yine sevgilinin âşık üzerindeki feyzinden bahseder:

Gonce-i hurşîd-i hüsnün kim eder 1zhâr-1 feyz

Bir yem-i envâr olur her şebnem-i gülzâr-1 feyz (sy. 431)

(Güzelliğinin güneş gibi goncası feyzi ortaya çıkarır; feyz gül bahçesinin her damlası nurun bereketi olur.)

Sevgilinin güzelliği âşık için bir 1şık ve berekettir. Feyz, sevgilinin başta âşık olmak üzere âleme verdiği bir ışıktır. Bu feyzden güneş de nasibini alır.

Tecelli ve Hz. Musa'nın Tur Dağı mucizesini Hikmet Bey “nihanız” redifli gazelinde de ele alır:

Ol şu'le-i aşkız ki tecellâda nihanız

Gûyâ ki şuâ'-1 yed-i beyzâda nihanız (sy. 442) sakliyız.)

(Aşk 1şığıyız ki tecelli sırrında saklıyız, güya Hz. Musa'nın mucize gösteren elinin 1şığında

Aşkın İlahî bir kaynaktan geldiği ve gerçek aşkın da yine geldiği yere Allah'a karşı kullanılması gerektiği düşüncesi tecelli ile birlikte ele alınır. Hz. Musa'nın Tur Dağı'nda Allah'la görüşmesi Allah'ın Hz. Musa'ya olan sevgisi ve Hz. Musa'nın aşkı ile gerçekleşir. Bu nedenle de âşı̆̆ın İlahî aşkta ulaşmak istediği son nokta Allah'la görüşebilmektir. Bu gazelde de tecelli ve aşk arasındaki bu bağ konu edilir. Namık Kemal de yine Hz. Musa ve Tur Dağı hadisesi ile ele alır:

Geh nûr-i cemâliz ki tecellâda nihanız

Gâhi nazar-1 hayret-i Mûsâ'da nihanız (sy. 442) sakliyız.)

(Bazen güzelliğin nuruyuz ki tecellide saklıyız; bazen Musa'nın hayret eden bakışında

Hikmet Bey'in sosyal konularla ilgili gazelleri oldukça azdır. Namık Kemal sayıca az olan bu gazellerden "fark var yoktur" redifli gazele nazire yazar. Hikmet Bey;

Hayâl-i câh u ikbâlin hevâdan fark1 var yoktur

Neşâtı varsa sekr-i ibtilâdan farkı var yoktur (sy. 445)

(İkbal ve makam hayalinin havadan farkı var yoktur; mutluluğu varsa bağımlılık sarhoşluğundan farkı var yoktur.)

Makam ve baht açıklığı insanlar için vaz geçilmez bir hayaldir. Ancak makam ve mevkilerin geçici oluşu insanı yanıltmaktadır. Hikmet Bey makam ve mevki hayalini havaya benzetir. Bunlar insana bir süre mutluluk verse de sahip olduktan sonra bağımlılık yaptı̆̆ için bu bağımlılığın verdiği sarhoşluktan bir farkı yoktur. Namık Kemal bu gazele yazdığı naziresinde konuya daha genel yaklaşır:

Sıfât-1 pâkinin zât-1 Hudâ'dan farkı var yoktur

Ziyânın mihrden mihrin ziyâdan fark1 var yoktur (sy. 445)

(Temiz sıfatının Allah'ın zatından farkı yoktur; Işığın güneşten güneşin 1şıktan farkı yoktur.) 
Vahdet anlayışı içinde değerlendirebileceğimiz bu şiirde her şeyin Allah’tan var olduğunu ve yine ona yansıdığı anlayışını hatırlatmakla yetineceğiz.

Namık Kemal'in encümen şairleri arasında gerek şiirlerine gerekse düşüncelerine önem verdiği ve etkilendiği diğer bir şair de Osman Şems Efendi'dir. Sûfî olarak bilinen Osman Şems Efendi şairliği ile de döneminde tanınır ve kabul edilir. Tasavvufa olan ilgisi nedeniyle kendisini bu alanda geliştiren ve mensuplarını irşad eden bir şeyhtir. "O, şiiri tasavvufî bir fikir ve kavramların anlatım aracı olarak gören mutasavvıf-şair değil vezin, dil, üslûp ve yeni mazmunlar kullanma açısından en az tasavvuf alanındaki yeri kadar değerli ve önemli bir şair-sûfîdir. Bu bağlamda Osman Şems Efendi’nin Şeyh Galib'e yakın bir şair olduğu söylenebilir.” (Azamat, 2007: 473) Şiire verdiği önem encümen şairleri tarafından takdirle karşılanır. Özellikle Namık Kemal'in dikkatini çeker. Namık Kemal'in encümen-i Şuara toplantılarına sekiz ay kadar devam eden Osman Şems Efendi'nin şiirlerinden etkilendiği kaydedilir. (Azamat, 2007: 474) Namık Kemal, Osman Şems Efendi’nin 15 gazelini tanzir eder.

Osman Şems Efendi, şiirlerinde tasavvufî olgunluk ve irşad esaslarından sıkça bahseder. "lâzımsa" redifli gazelinde marifet mektebinde üstat arayanlar için kendisini adres olarak gösterir:

Debistân-1 maârifete kime üstâd lâzımsa

Beni ekmel bulur ol bâbda irşâd lazımsa (sy. 275)

(Maarifet mektebinde kime üstad lazımsa, irşad lazımsa o kapıda beni kemâle ermiş bulur.)

Osman Şems Efendi'nin Nakşi tarikatında bir kolun şeyhi olduğu bilinmektedir. Osman Şems'in melamet meşrebi ve üveysîlik kolunu birleştirerek ayrı bir yol oluşturması ve kendisinden sonra gelenler için tarikat hilafetini devam ettirmesi onun tasavvufî şiirlerinin anlaşılmasını sağlar. Namık Kemal'in tarikat silsilesi içerisinde olmaması onun tasavvufî şiirlerdeki anlam derinliğini azaltmaz. Ancak o tasavvufî 1stılahın terminolojisini daha genel anlamda kullanır:

Tarîk-1 hakta cân ü tenden olmak yâd lazımsa

Beni hâzır bulursun her çi bâd âbâd lazımsa (sy. 275)

(Hak yolunda can ve bedenden vazgeçmeyi hatırlamak lazımsa, her ne olursa olsun kabul edilirse beni hazır bulursun.)

Namık Kemal, Osman Şems'in gazeline cevap niteliğinde bir gazel yazar. Osman Şems'in irşad olmak isteyen beni kâmil bulur ifadesi karşısında şair, eğer bir özellik aranmıyorsa kendisinin irşad olmak için hazır olduğunu belirtir.

Aşk şarabı, divan şiirinde şairlerin birçok kere tekrar ettiği mazmunlardan biridir. Âşık, aşk şarabının sarhoşudur. Osman Şems'in "şerâb" redifli şiirinde bu durum söz konusudur:

Mest-i sahbâyim dehânımdan gelir bû-yi şerâb

Mevc-i tesbîh-i zebanımdan gelir bû-yi şerâb (sy. 277) gelir.)

(Sabah sarhoşuyum ağzımdan şarab kokusu gelir, zayıf tesbih dalgasından şarab kokusu

Geceyi zikir ve teşbihle geçiren âşığın sabah olduğunda aşkın verdiği coşku ile yaşadığı sarhoşluk kendinden geçme ve mest halini yaşar. Bu âşığın varmak istediği bir haldir. Namık Kemal aşk sarhoşluğunu doğrudan ifade eder:

Mestim eşg-i hunnisârımdan gelir bûy-i şerâb

Âbrû-yi iftikârımdan gelir bûy-i şerâb (sy. 277) 
(Kan saçan göz yaşımdan gelen şarab kokusu ile sarhoşum, tevazuumun kaşlarından şarab kokusu gelir.)

Göz yaşı, âşığın aşkının somut göstergesidir. Kanlı göz yaşının aşk şarabının kokusunu taşıması ve âşığın tevazuundan dolayı bunu gözünden değil kaşlarından geldiğini söylemesi aşkın samimiyet derecesini gösterir. Namık Kemal'in aşktaki samimiyet algısında Osman Şems Efendi'nin fikirlerinin etkisi olduğunu söylemek mümkündür.

Aşk derdi âşı için istenen ve çaresi olmayan bir hastalıktır. Âşık tarafından sürekli şikâyet edilse de âşık bu hastalıktan kurulmak istemez:

Külbe-i firkatte kaldım oldu cânan nâbedîd

Düşmüşüm bir derde kim âlemde derman nâbedîd (sy. 289)

(Ayrılık kulübesinde kaldım sevgili belirsiz, âlemde bir derde düşmüşüm dermanı belirsiz.)

Namık Kemal'in tanzir ettiği şiirde zamanla aşkta ve değerlerde meydana gelen değişim söz konusudur. Namık Kemal, Osman Şems ile benzer bir kavram bütünlüğü oluşturur:

Dil hevâ-yı aşk ile aşüfte cânan nâbedîd

Fitne berbâd eylemiş tahtın Süleyman nâbedîd (sy. 289) belirsiz.)

(Gönül aşk havası ile çılgına dönmüş sevgili belirsiz, tahtı fitne berbat etmiş Süleyman

Âşık, aşk için hazırken ona karşılık verecek sevgili ortada yok, her şeye hükmeden Süleyman nasıl tahtında değilse sevgilinin olmaması da o tahtın berbat olmasına, yıkılmasına sebep olur. Âşık ile sevgilinin arasını açan da fitnedir.

Beden ve ruh ilişkisi tasavvufta ayrı bir öneme sahiptir. Bedenin faniliği ve ruhun bedenden sıyrılarak ebedi bir hayata kavuşması tasavvufî şiirlerin başlıca konuları arasındadır. Ruh, beden kafesinde hapsolmuştur ve bedenin ölümü ile özgürlüğüne kavuşacaktır. Bu nedenle de insan için asıl beden ruhtur. Osman Şems gazelinde;

Sûretâ kim külbe-i ahzân meskendir bize

Lîk rûh-i a'zamız iki cihan tendir bize (sy. 302)

(Görünüşte hüzün evi bize meskendir, lakin ruhumuz iki cihanda asıl bedenimizdir.)

mısralarında ruhun kalıcılığı üzerinde durur. Namık Kemal bu şiire yazdığı nazirede ise tecelli sirrından bahseder:

Bülbül-i me’yûs-i aşkız Tûr gülşendir bize

Hande-i verd-i tecellî âh-1 şivendir bize (sy. 301)

(Aşkın kederli bülbülüyüz, Tur (Dağı) bize gül bahçesidir, tecelli gülünün gülüşü bize matemin âhıdır.)

Allah'ın Tur Dağg'a tecelli ederek Hz. Musa ile konuşması, insanla Allah'ın kavuşma anının bir simgesidir. Namık Kemal'in bu hadiseye özel bir ilgi duyduğunu ve bu anlamı sıkça vurguladığını diğer şiirlerde de söylemiştik. Bu şiirde de şair, Tur Dağı'ndaki tecelli âşı için istenilen arzu edilen bir şeydir. Ancak buradaki tecelli ve sonrasındaki ayrılık ve hasretin devam etmesi âşık için yine mâtem sebebidir.

Birçok şairin aynı tarzı kullanarak yazdığı “zülf ü hâl ü ruh” redifli gazel geleneğine Osman Şems de dahil olur: 
Bâğ-1 hüsne tohm-i zîverdir o zülf ü hâl ü ruh

Sebze vü sünbül ve gülterdir o zülf ü hâl ü ruh (sy.309)

(O saç teli, hal ve ruh güzellik bağının ziynetli tohumudur, o saç teli, hal ve ruh sebze, sümbül ve taze güldür.)

Sevgilin saçı, tavırları ve karakteri âşı̆̆ 1 cezbeden ve aşk acısı çekmesine neden olan göstergelerdir. Sevgili bir güzellik bahçesi ise bunlar o bahçenin en değerli ziynetleridir. Osman Şems'in de önceki şairlere nazire olarak yazığı bu şiir tarzında Namık Kemal'in de bir gazeli vardır:

Âsmân-1 hüsne zîverdir o zülf ü hâl ü ruh

Mâh-1 enver şâm ü ahterdir o zülf ü hâl ü ruh (sy. 308)

(O saç teli, hal ve ruh güzelliğin gökyüzüne zinettir, o saç teli, hal ve ruh akşam ve yıldız 1şığının ay'ıdır.)

İnsan beden verilerek dünyaya gönderilmeden, "kalu belâ" anında Allah'1 Rab olarak kabul eder. Ruhların Allah'ı kabul ettikleri andan itibaren ona karşı duyulan aşk da varlığını devam ettirir:

Câmesûz-i kâle-i cism olmadan can riştesi

Nâr-i aşkın pertevinden oldu îman riştesi (sy. 319)

(Can ipliği cismin elbisesiz bir kalesi olmadan, iman ipliği aşkın ateşinin ışı̆̆ı oldu.)

Namık Kemal tanzir ettiği şiirinde;

Sûzen-i tahrire serbend olmadan can rîştesi

Halka-i zünnâr idi uşşâka îman riştesi (sy. 319)

(Can ipliği, yazı iğnesinin başına sarılmadan, iman ipi âşıklara kuşak halkası idi.)

mısralarında henüz kader yazılmadan, imanın âşıklar için bir kuşak gibi etrafını sardığını belirtir. Namık Kemal'in özellikle Tasavvufî ıstılahta olan bu düşünceyi şiirleştirirken Osman Şems'in etkisinde kaldığı görülmektedir.

Kanlı göz yaşı, âşığın göz yaşının kan olması mazmunları divan şiirinin en bilinen ifadeleridir. Bu âşığın acısını ve içinin kan ağladığının bir göstergesidir. Âşığın bu hâli bulunduğu yere bir canlılık katar. Aşkın en somut ifadesidir:

Hâk olup hûnâbe-i eşg-i terimden renk renk

Gülşen oldu katre-i feyz âverimden renk renk (sy. 323) oldu.)

(Kanlı göz yaşımdan renk renk toprak olup feyz getiren damlamdan renk renk gül bahçesi

Namık Kemal “renk renk” redifli gazelinde hem Osman Şems’ten hem de Galip Bey’den etkilenir:

Şu'le dilden cûş eder sevdâ serimden renk renk

K11 nigâh âsâr-1 aşka peykerimden renk renk (sy. 322)

(Başımdaki sevdadan renk renk gönül alevi coşar, yüzümden renk renk aşkın eserlerine bak.)

Âşı ğın aşkının ifadesi gazellerde farklı şekillerde anlatılır. Şair göz yaşı yerine doğrudan gönülden bahseder. Namık Kemal, tanzir ettiği şiirlerde genellikle sebep sonuç ya da parça bütün ilişkisine uygun şiirler yazar. 
Dilde tâb endâz olup sevdâ-yi nâzefzâ-yi aşk

Yaktı can mülkün serâser âteş-i bâlâ-yi aşk (sy. 325) yaktı.)

(Gönülde aşkın naz artıran sevdası parlarken, aşkın yüce ateşi baştan başa can mülkünü

Osman Şems'in aşk ateșinin izlerini yüzde aramasına karşın Namık Kemal aşk ateşinin yakıcılığı üzerinde durur. Anlam olarak aşk ateşi konu edilmiş olsa da Namık Kemal'in şiiri ahenk unsurları bakımından daha zengindir.

Osman Şems, müridlerini irşad yolunda bazı konuları şiir şeklinde ifade eder. İman ve küfür, Müslüman ve kâfir arasındaki ayrım da bu konular içerisindedir:

Ehl-i imân oldur eyler secde cânânım görüp

Kâfir oldur mak'eylemez îmân îmânım görüp (sy. 367)

(İman ehli sevgilisini görüp secde eder, kafir imanımı görüp yine de iman etmez.)

İnanmak, iman etmek bir aşk işidir. İnsan Allah'a aşkla bağlanması ile kâmil bir imana ulaşabilir. Bu aşka ulaşınca da secdeye kapanır. Kâfir ise aşkla yapılan bu secdeyi anlamaktan uzaktır. Namık Kemal bir karşılaştırma yapmaz, kendi aşkını anlatmakla yetinir:

Aybeden sevdâ-yi aşkı sûz-i hicrânım görüp

Âteş-i gayretle yansın şimdi cânânım görüp (sy. 366)

(Aşk sevdamı, ayrılık ateşimi görüp ayıp eden sevgiliyi görüp gayret ateşiyle yansın.)

Âșığın halinden anlamayan, onun çektiği acıya anlam veremeyenler sevgiliyi gördüklerinde onlar da âşığa hak vereceklerdir. Âșık, așk acısının kaynağını göstererek kendi çektiklerini anlaşılabilir kılmak ister. Osman Şems'in gazeli ile bir anlamda zıt bir anlam içerir. Osman Şems iman ehli ile kâfir arasında bir kıyaslama yaparken kendi imanından sevgiliye ulaşmalarını bekler. $\mathrm{Bu}$ onun mürşid olma durumundan kaynaklıdır. Ancak Namık Kemal bu ayrımı açıkça belli eder. Eğer onu görerek onun aşkına ayıp edenleri sevginin kaynağına yönlendirir. Bu iki şiir arasında mürşid - mürid ayrımını görmek mümkündür.

Bedenin can için bir kafes olduğu ve canın bu kafesten kurtulduğu zaman özgürlüğüne kavuşacağı düşüncesi beden ve ruh arasındaki ilişkiyi konu edinen diğer şiirlerde de sık sık kullanılır. Osman Şems kuş ve can arasındaki bağı şöyle açıklar:

Bir tâir-i kudsüm ki felekler kafesimdir

Bu ten kafesi lâne-i bî hâr ü hasimdir (sy. 384)

(Bir kuddüs kuşuyum ki felekler kafesimdir, bu ten kafesi düşmansız ve dikensiz bir evdir.)

Namık Kemal bu şiire yazdığı nazire de yine Tur Dağı hadisesine telmihte bulunur:

Bir bülbül-i Tûr'um dil-i Mûsî kafesimdir

Sıyt-1 Erini nâle-i âteş nefesimdir (sy. 384) nefesimdir.)

(Bir Tur (Dağı) bülbülüyüm Musa'nın gönlü kafesimdir, şöhretim ateşin iniltisi olan 
Âşık, kendisini Hz. Musa ile birlikte Allah'la görüştüğü konuştuğu anda hayal eder. Orada sadece Hz. Musa vardır; ancak âşık onun gönlündedir. Osman Şems'in ten kafesi mazmunu, Namık Kemal'de daha farklı ele alınır. O kendisini tecelli anında hayal eder.

Sevgilinin kaşları âşık için kan dökücü özelliğe sahiptir. Âşş̆̆ büyüleyen sevgilin oka benzeyen kaşlarıdır. Sevgilinin dudakları ise âşığın ulaşmak istediği bir şekilde ulaşmak istediği yerdir. Kılıç gibi keskin dudaklar, âşı̆̆a acı ile birlikte haz verir. Osman Şems'in bu gazelinde kullandığ1 leb mazmunu divan şiirine kattı̆gı bir yeniliktir. Dudakların keskin olması ve bu keskinlikle gönlü parçalaması divan şiirinde farklı benzetmelerle ulaşılmak istenen yer olarak kullanılan dudağa farklı bir hayal yükler:

Ey perî her dil füsun i tîg-1 müjgânındadır

Kangı dil kim var leb-i şemşîr-i bürrânındandır (sy.389)

(Ey peri, her gönül büyüsü kaşlarının okundandır. Hangi gönül varsa keskin kılıcının dudaklarındandır.)

Namık Kemal, Allah aşkının anlatıldığı bu gazeli tanzirinde daha açık ifadeler kullanır:

Kişver-i imkân serâser zîr-i fermanındandır

Sûre-i Innâfetahnâ gamzenin şânındandır (sy. 389)

(İmkân ülkesi baştan başa fermanının altındadır, Innafetâhnâ suresi gamzenin şanındandır.)

Allah, bütün kâinatın baştan başa tek ebedi ve ezeli hâkimidir. Her şey O’nun izniyle gerçekleşir. Innafetahna suresi ${ }^{10}$, fethin inananlar için olduğunun müjdelenmesi ve zorluklar karşısında Allah'ın insanların yanında olduğunu bildirmesi bakımından önemlidir. Zorluk döneminde bu sure, Allah'ın inananları bırakmadığını, bırakmayacağını müjdeler. Şair, bu sureyi sevgilinin âşı̆ga bir bakışı ile ifade eder. Namık Kemal bu şiiri tanzir ederken Fuzuli ve Osman Şems'ten etkilenir. Ancak kendisi de orijinal bir anlatım elde eder. Bu şiirin bu anlamda başarılı bir şiir olduğunu söylemek istiyoruz.

Nefsin arzu ve istekleri, âşık için bir engeldir. Onlara ulaşabilmek için sevgiliye olan ilgisi azalır. $\mathrm{Bu}$ arzu ve isteklerin yok edilebilmesi için ümitsizlik, onlara ulaşamama fikrinin insanda yerleşmesi gerekir. Aşk şarabı ile sarhoş olmuş âşığın gönlünde aşka bir arzu ve istek söz konusu değildir. Osman Şems bu düşünceyi "ârzû" redifli gazelinde açıklar:

Seng-i ye's ile şikest oldu tefağ-1 ârzû

Söndü işretgâh-1 sinemde çerâğ-1 ârzû (sy.412)

(Arzu ve istekler ümitsizlik taşı ile kırıldı, arzu çırası gönlümün içki meclisinde söndü.)

Namık Kemal de arzuyu bitiren, yok eden nedenin sevgilinin bir selamı olarak görür:

Bir selâmınla açup bir lâle dâğ-1 ârzû

Benzedi gülzâr-1 İbrâhim'e bâğ-1 ârzû (sy. 412)

(Arzu yarası bir selamınla lale açıp arzu bağının İbrahim'in gül bahçesine benzedi.)

Sevgilin bir selamı, âşığın bütün dünyasını değiştirir. Sevgili selamla ona ilgi göstermiş, ona değer vermiş olur. Dünyevî arzular âşığı sevgiliden uzaklaştıran engellerdir. Hızla ona doğru

\footnotetext{
${ }^{10}$ Fetih Suresi Kur'an'1 Kerim'in 48. Suresidir. Mekke'nin fethedileceği müjdesini içerir.
} 
giderken sevgilinin bir selamı ${ }^{11} \mathrm{o}$ ateşten bağı, İbrahim'in bahçesine çevirir. Aşk, ateşi gül bahçesine çeviren bir etkiye sahiptir.

Divan şairlerinim birçoğu "farkı vardır yoktur" redifli gazel yazmıştır. Bu gazeller bazen telif bazen de nazire olarak kaleme alınır. Osman Şems'in de aynı redifli yazdığı gazel, aynı dönemde Hersekli Arif Hikmet tarafından da yazılır:

Bu gülzâr- fenanın kim bekadan fark1 var yoktur

Fezâ-yi mahşer-i dehşetnümâdan fark1 var yoktur (sy. 445)

(Bu fani gül bahçesinin bekadan farkı var yoktur, dehşet gösteren mahşerin korkusundan fark1 vardır yoktur.)

Dünyadaki nimetler gelip geçicidir. Eğer dünya nimetlerindeki hikmeti görüp onu veren hatırlanırsa ona âşı olunursa bu nimetler ebedi devam edecek nimetlere dönüşüdür. Farkın olması için bu farkın âşık tarafından fark edilebilmesi gerekir. Namık Kemal de:

Sıfât-1 pâkinin zât-1 Hudâ'dan farkı var yoktur

Ziyânın mihrden mihrin ziyâdan fark1 var yoktur (sy. 445)

(Temiz sıfatının Allah'ın zatından farkı yoktur; Işığın güneşten güneşin 1şıktan farkı yoktur.) mısralarında benzer bir anlamı vurgular. Eğer kainattaki tecelli sırrı anlaşılırsa o zaman yaratan ve yaratılan arasındaki sır anlaşılabilir.

19. yy. şairlerinden Arpaeminizâde Mustafa Sâmi Efendi, Namık Kemal'in şiirlerini tanzir ettiği encümen şairlerindendir. Namık Kemal Sâmi Efendi'nin 8 gazeline nazire yazar. Hikemî ve düşündürücü konularda şiir yazan şair, mazmun, nükte ve mânayı ön plana almakla birlikte lafza da önem vermiştir (Kutlar 2006: 354-356).

Sâmi Efendi, dünya malının geçiciliği, dünyanın fâni oluşu gibi konularda hikemî şiirler yazar. Şairin bu hikemî, düşündürücü tarzı Namık Kemal'in ilgisini çeker. Kendi fikir dünyasının oluşmasında Sâmi Efendi'den oldukça yararlanır. Sâmi Bey’in;

Nedir sudu bu bâzâr-1 fenâda celb-i emvâlin

Gınâ vermez metâ-1 müsteârı dûş-i dellâlin (sy. 359)

(Bu fâni pazarda mal edinmesinin kârı nedir, dellalın omzundaki kendine ait olmayan mal zenginlik vermez.)

matlalı gazelinde dünya malının emanet olarak insana verildiğini ve bu emanet maldan dolayı da insanın zengin olmasının anlamsız olduğunu vurgular. Namık Kemal' de benzer bir yaklaşım sergiler:

Çekilmez bir belâdır bâr-1 derdengîzi emvâlin

Olur, feryad her dem ol sebepden kârı dellâlin (sy. 359)

(Malın denge bozan yükü çekilmez bir belâdır, dellalın kârı bu sebepten her dem feryâddır.)

Dünya malını bela olarak gören şair, dellalın mal taşımaktaki kârı onu taşırken ettiği feryatlardır. Bu düşünce tasavvufun üzerinde durduğu belli başlı konulardandır.

\footnotetext{
${ }^{11} \mathrm{~Hz}$. İbrahim, ateşe atıldığında Allah Cebrail'e onu ateşin yakmamasını ve bürudetiyle de dondurmamasını ister. Ateş onu selamete çıkaracaktır. Kur'an'ı Kerim'de Enbiya suresinde (21/69), bu durum şöyle anlatılmaktadır: "Ey ateş, İbrahim'e karşı soğuk ve esenlik ol.”
} 
Divan şairlerinin birçoğunun "o zülf ü hâl ü ruh" redifli gazel yazdığı bilinmektedir. Sâmi Efendi de aynı redifli bir gazel yazar:

Bezm-i pâk-i hüsne ziverdir o zülf ü hâl ü ruh

Dûd-i anber micmer-i zerdir o zülf ü hâl ü ruh (sy.309)

(O saç, hal ve ruh güzellik temiz meclisinin süsü, amber dumanı altın buhurdanlıktır.)

Sevgilinin güzelliği klasik mazmunlar içerisinde çok farklı şekillerde tarif edilir. Sâmi Efendi de sevgilinin bulunduğu meclise güzellik veren, amber kokusunu konu edinir.

Sâmi Efendi, kapalı bir anlatımı tercih eder. Mahalli söyleyişlerden uzak duran şairin sebk-i Hindi tarzını benimsediği bilinmektedir. Bazı şiirlerindeki kapalılık ve anlaşılmazlığın temeli şairin bu anlayışıdır. "iki" redifli gazeli de kapalı bir anlatıma sahiptir:

Hayf kim fülk-i Güher meşhûn bir deryâ iki

Cuşiş-i eşge dil-i pür hûn bir mecrâ iki (sy. 313)

(Eyvah ki iki deniz bir dolu Güher gemisi, göz yaşının coşmasına iki yer bir kan dolu gönül.)

Şair, kesret ve vahdet arasındaki dengeyi, gemi ve deniz arasındaki ilişki ile anlatır. Namık Kemal'in gazelinde;

Kâmkâh olmuş dil-i mâhzûn bir dünya iki

Hayf sâhil cûy olan meftun bir deryâ iki (sy. 313)

(Arzu yeri olmuş kederli gönül bir dünya iki, yazık sahili büyülenmiş nehir bir deryâ iki.)

Gönlün dünya ve ebedî âlem arasındaki halini anlatır. Ne bu dünyadan vazgeçebilir ne de ebedî âlemden. Bu ikilem de hayat boyu devam eder. Denize doğru akan nehir de iki denizle karşılaşır: nehir olmadan denizin kendi hali ve nehrin denize karışması ile sahilde oluşturduğu deniz. İnsan bu ikilem arasında teki bulmak ve vahdeti görmek için çaba sarf eder.

Sâmi Efendi hayatın geçiciliği ve asıl olanın ahiret âlemi olduğu inancına birçok şiirinde değinir. Bu dünyanın zevk ve safa ile geçen hayatı kadehin arka tarafının görünmesi gibi kesin ve yakındır:

Dübâlâdır mey-i sâfile ayş-1 yekdem-i âlem

Olur âyine-i sâgarda dîğer âlem-i âlem (sy. 328)

(Âlemin yiyip içmeden ibaret hayatı çok az bir içkinin iki katıdır, âlemin diğer âlemi kadeh aynasinda olur.)

Namık Kemal'in “âlem" redifli şiirinde yine vahdet sırrı konu edilir. Allah'ın âlemi tek bir elden yaratması insanların da bu birlik içerisinde rahmete ulaşma ümidini artırır. Gidilecek başka bir yer olmaması bu birliğin gereğidir:

Olur, peydâ ümid-i neyl-i rahmetten hem-i âlem

Budur fasl-ul-hitâb-1 şerh-i râz-1 mübhem-i âlem (sy. 327)

(Âlemin birliği rahmete ulaşma ümidini ortaya çıkarır, âlemin gizli mimarının hitap faslının açıklaması budur.)

Sevgilinin dudağını öpme isteği âşı̆̆ın ulaşmak istediği tek noktadır. Âşık hep bunun hayalini kurar. Sevgilinin kırmızı dudağı, kırmızı gül gibi kıvrımlıdır. Ancak âşık çok istemesine 
rağmen bu isteğine kavuşamaz. Sevgili buna izin vermediği gibi bu düşünceden de utanır ve pembe gül gibi yüzü kızarır:

Nigeh gülbûse çîn olmak ne mümkin lâ'l-i nâbından

Olur, gülpûş-i hayret sürh-i reng-i hicabından (sy. 345)

(Saf kırmızı dudağından bakışın gül gibi kıvrımlarını öpmek ne mümkün, utancının kırmızı renginden hayretin pembe gülü olur.)

Divan şiirin klasik anlatımlarından olan bu gazeli Namık Kemal de sevgilinin utancından ve âşığın bu utanç karşısındaki tutumundan bahseder:

Değildir girye peydâ eyr-i rûy-i şu'le tabından

Fürûg-1 çeşm-i hasret âb olur tâb-1 hicabından (sy. 344)

(Huyunun 1ş1klı görünümünden göz yaş1 ortaya çıkar, utancının parıltısından hasret gözünün 1şı̆̆ su olur.)

Sâmi Efendi bazı gazellerinde ise kısmen daha sade bir dil kullanır. Kader konusunu ele aldığ 1 gazelinde bahtın kapanmasını, kötü talihi feleğe bağlamaz, fakat sebebini düşünmekten de kendini alamaz. Kötü talih divan şiirinde genelde felekle bağ kurularak ele alınır ve kötü talihten felek suçlanır. Âşığın bu dünyadan şikayetçi olmasının temel nedeni de felek olarak gösterilir. Sâmi Efendi ise kötü talihi feleğe bağlamaz. Üzerinde düşünülmesi gereken bir olgu olarak görür. Bu anlayışın da divan şiirinden farklı olduğunu ve şiirde anlam bakımından bir yenilik olduğunu söyleyebiliriz:

İhtirâk-1 necm-i bahtı bilmeziz eflâkten

Âh kim yandık tutuştuk şu'le-i idrakten (sy. 353)

(Baht yıldızının yanmasını felekten bilmeyiz, âh ki düşünce parıltısından yandık tutuştuk.)

Namık Kemal de feleğin insanlara verdiği haz ve zevklerinin hikmetli, bir amaca yönelik olmadığını söyler. Asıl akıl göstergesi düşünmekten ve hikmetten kaynaklanır. Bu şiirde Namık Kemal, Sâmi Efendi’nin hikmet anlayışını konu edinir:

Görmedik bir tavr-1 hikmet cünbiş-i eflâkten

Akl-1 kül var ise kalmış kuvve-i idrakten (sy. 353)

(Feleğin eğlencesinden hikmet görmedik, külli akıl varsa bu idrak gücünden kalmıştır.)

Vahdet konusu tasavvufun en önemli konusudur. Vahdetin ifade edilmesi, farklı örneklerle Allah'ın birliğine işaret edilmesi divan şairlerinin ortak özelliklerindendir. Sâmi Efendi de "bir" redifli gazelinde vahdeti örneklendirir:

Bezm-i vahdet kim olur tertîb-i ruhefzâsı bir

Oldu câm ü sâki vü meyhâne vü sahbâsı bir (sy. 377)

(Ruh verici düzenin bir olması vahdet âleminin eseridir, meyhane ve sehpası, içki taşıyan ve kadeh bir oldu.)

Vahdet anlayışını işleyen Namık Kemal, kesret ve vahdet ilişkisi üzerinde durur. Sâmi Efendi'nin âlemdeki düzeni birlik ile açıklamasını Namık Kemal yaratıış mayasının aynı olması ile açıklar. Varlık âlemi çok çeşitli olsa bile bu suretlerin, görünüşlerin her biri kendi mayasındaki birliğin bir dışa vurumudur: 
Âlem-i fitrat ki olmuş mâye-i eczâsı bir

Görünür her suret ile cevher-i meclâsı bir (sy. 377)

(Yaratılan âlem ki her şeyin mayası birdir, her suret ile aynasının cevheri görünür.)

Âşığın sevgilinin ayrılığıyla aşk acısı çekmesi, kederli bir ruh hali karakteristik bir özelliktir. Sâmi Efendi, âşık ve sevgili arasındaki bu istek ve arzuya yeni bir bakış açısı getirir. Âşık gam meclisinde içkidir, sevgilinin nun (harfine benzeyen) dudağına değmek ister:

Bâde-i bezm-i gamım reng-i ruh-i dil hastedir

Câm-1 şevkım nûn-i ma'kûs-i hatt-1 şikestedir (sy. 382)

(Gam meclisinin içkisiyim gönül ruhunun rengi istenildiği gibidir, şevk kadehiyim ki (bu) yazının uğursuz nununun hattıdır.)

Namık Kemal bu şiire yazdığı naziresinde âşığın sevda iniltilerini sohbet meclislerindeki saz fasıllarına benzetir. Aşı̆̆ın iniltileri kendisi için bir mutluluk kaynağıdır. Sevgili nedeniyle inlemek âşığın aşkının devam ettiğinin bir göstergesidir.

Çeşmime pegale-i nahvet dil-i şikestedir

Sâz-1 sohbet nâle-i sevdâ-yi cân-1 hastedir (sy. 382)

(Gözüme kibrin hissesi kırık gönüldür, sazlı sohbet hasta canın sevda iniltileridir.)

Namık Kemal, Sâmi Efendi'nin gazellerinden gerek düşünce gerek üslup olarak etkilenir. Sâmi Efendi'nin Tasavvufî konulardaki düşünceleri ahiret hayatını ön plana çıkartırken Namık Kemal bu şiirlere yazdığı nazirelerinde sadece bu dünyadan ve dünya nimetlerinden dert yanmakla yetinir. Bu anlamda Namık Kemal arada kalmış bir görüntü vermektedir. Ahiret için bir arzu olmasa da dünyanın zevk ve eğlencelerinden, feleğin verdiği belâlardan şikâyet söz konusudur. Sâmi Efendi çözüm için ahireti gösterirken Namık Kemal bir çözüm önermez.

Encümen şairlerinden İbrâhim Hâlet Bey şiirde çok başarılı olmamasına rağmen Namık Kemal onun 5 şiirine nazire yazar.

Sevgilinin güzelliğinin parıltısı ve bu parıltının âşı̆̆ı etkilemesi divan şiirinde sıkça işlenen bir konudur. Hâlet Bey'in âftâb" redifli gazeli de bu anlamı içerir. Güneş sevgilinin güzelliğinden 1şı̆̆ını alır, ve bu 1şığı âşı̆̆ın üzerine yansıtır. Eğer güneş sevgilinin ışığından almamış olsa insanların güzel ve güzellikten haberi olmazdı. Mahşerde gerçek güzeli Allah'1 gördüğünde ancak güzeli ve güzelliğin ne olduğunu anlayabilecektir:

Almasa tâb-1 ruhinden nûr rûy-i âftâb

Âlem etmez tâ be-mahşer ârzû-yi âftâb (sy. 279)

(Güneş, ruhunun parıltısından nur almasa âlem mahşere kadar güzeli arzu etmez.)

Namık Kemal, Hâlet Bey'in bu gazeline yazdığı nazirede benzer bir anlam kullanır. Bu gazel, Hâlet Bey'in gazelinden farklı değildir:

Şem'-i hüsnün olsa feyzefzâ-yi sû-yi âftâb

Fer verir mişkât-1 arşa reng-i rûy-i âftâb (sy. 279) verir.)

(Güzelliğinin 1şığı, güneşin kötü 1şığı olsa, güneşin yüzünün rengi arşın kandiline parlaklık

\section{Turkish Studies - Language and Literature}

Volume 14 Issue 4, 2019 
Âşı ğın aşkından inlemesi, acı çekmesi benzer hayallerle anlatılır. Divan şiirinde âşı̆̆ın âhının gökyüzündeki ya da kandilden çıkan dumana benzetilmesi, bununla birlikte âşığın da 1şık saçması, etrafı aydınlatması ya da güneşe ışı vermesi sıkça kullanılan hayallerdir. Hâlet Bey de bu anlayışa uygun gazeller yazar. Bu gazellerde bir yenilikten bahsetmek neredeyse imkânsızdır:

Ebr-i pür dûd-i sipihr-i Lâmekândır âhımız

Kim hümâ-yi feyz-i aşka âşiyandır âhımız (sy. 425)

(Âhımız mekânsız göğün çok dumanlı yağmuru, aşkın feyizli mutluluğunun yuvasıdır.)

Namık Kemal aynı redifli gazelinde âşıkların âh çekmesi dolayısı ile aynı ailenin bireyleri olduklarını söyler. $\mathrm{Bu}$ aile ise aşkta mahvolmuş, mertebe kat etmiş kudsilerin beğenisi, takdirini kazanmıştır. Namık Kemal'in nazire olarak yazdığı şiirinin Hâlet Bey'den hem söyleyiş hem de anlam olarak daha zengin ve başarılı olduğunu söyleyebiliriz:

Dûdman zîb-i fürûg-i sûz-i candır âhımız

Mahv-i aşkız nûr-i çeşm-i kudsiyandır âhımız (sy. 424)

(Âhımız canın yakıcı ışık saçan süsünün ailesiyiz. Aşkın mahvettiği kimseleriz, âhımız kudsîlerin gözünün nurudur.)

Mesih olarak adlandırılan Hz. İsa, ölüleri diriltme mucizesi ile bilinen ve şairlerin çok sıkça başvurduğu bir kişidir. Âşı̆̆ın cansız bedenine sevgili Mesih gibi can verir. Dünya işlerine aldırış etmeyen rindden bahseden Hâlet Bey, dünyanın âşığın kendi etrafında döndüğünü söyler:

Rind-i nâkâmım felekler seyr-i etvârımdadır

Öyle cansûzum Mesîhâ fikr-i esrarımdadır (sy. 436)

(Zevk alamayan bir rindim, felekler tavırlarımın yolculuğudur, öyle cansızım (ki) Mesih sırrımın düşüncesindedir.)

Namık Kemal tanzirinde rindlik yerine şairliğinden bahseder. Şairin sözü, mananın vahiy olmasıdır ve İlahîdir. İki cihanın sırrı da yine bu sözlerde saklıdır:

Şâirim vahy-i maânî lûtf-i güftârımdadır

Nükte-i sırr-1 dü âlem levh-i efkârımdadır (sy. 436)

(Şairim, mananın vahyi sözümün lütfundadır, İki âlemin sır nüktesi, düşüncemin ortaya çıkmasındadır.)

Âşığın vücudundaki aşk yaraları şairlerin çok farklı hayallerine konu olur. Bazen gül gibi açılması, âşığın aşkını, bağlılığını göstermesi, sevgiliden bir iz olması gibi anlamlarda kullanılır. Hâlet Bey, âşığın vücudundaki yaraları ona bakanlar için bir pencere olarak görür. Âşığın gafleti, vurdumduymazlığı onun vücudunda açılan yara gibidir. Bu yara âşığın gönlünün, gönlündeki aşkın görülebilmesi için bir pencere gibidir.

Sîne kim dâğ-1 tegafülden serâpâ yâredir

Her biri seyr-i cemâle revzen-i nezzâredir (sy. 437)

(Gönül, gaflet yarasından baştan ayağa yaralıdır, her biri güzelliğin seyri için seyirci penceresidir.)

Namık Kemal bu gazeli tanzir ederken oldukça farklılaştırır. Hâlet Bey'in diğer şiirlerine göre daha başarılı olan gazelindeki anlamı kendine has bir üslup ve anlam ile yeniden oluşturur: 
Dil ki şevk-i mihr-i hüsnünle serâpâ yâredir

Cûş eden her pâresinden şu'le-i nezzâredir (sy. 437)

(Gönül baştan ayağa güzelliğinin güneşinin isteği ile yaralıdır, her parçasından coşan seyircilerin pariltısidır.)

Gönül, sevgilinin 1şığını içine alabilmek için baştan ayağa yaralıdır. Bu mısrada âşığın yarasına faklı bir anlam yüklenir. O yaralardan coşan, yansıyan, parlayan ise o yaraya bakanların verdiği 1şıktır. Âşık kendisine nazar edenlerin verdiği ışı̆̆a bir aynadır.

Âşığın aşkından rezil olması, aslında onun için bir rütbedir. Aşkından en çok rezillik çeken en değerlidir. Aşkta rezillik aşkın derecesini göstermesi bakımından önemlidir. Halet Bey, melameti şöyle tarif eder:

Kasr-1 feleği neyleye sekran-1 melâmet

Meyhânede baş gûşedir eyvân-1 melâmet (sy. 441)

(Feleğin köşkünü, melamet sarhoşu ne yapsın, meyhanede melamet köşkü baş köşedir.)

Dünya malının, makamının âşık için hiçbir değeri yoktur, onun gözünde de değildir. Önemli olan âşıklar içinde aşkından rezil olmuş, kınanmış bir âşık olarak yer edinebilmektir. konusudur:

Namık Kemal'in melameti konu edindiği gazelinin matla beytinde benzer bir anlam söz

Aşkın ki olur mâye dih-i şân-1 melâmet

Cibrîl'i eder silsile cünbân-1 melâmet (sy. 441)

(Aşkın melametin şan veren mayası olur, Cebrail'i melametin hareket eden silsilesi yapar.)

Hâlet Bey'in şiirlerinde orijinal ve divan şiirine yeni bir bakış ya da üslup kazandıran şiirleri olduğunu söylemek oldukça zordur. Daha çok klasik anlayışı devam ettiren şair, kendine has bir tarz da geliştiremez. Namık Kemal, Hâlet Bey'in şiirlerine nazire yazarken diğer şairlerde olduğu gibi kendisini geliştirmek, öğrenmek ya da onun kadar başarılı olduğunu göstermek amacıyla değil Hâlet Bey'in de encümen şairlerinden olması dolayısı ile şiirlerine nazire yazdığı anlaşılıyor. Namık Kemal'in diğer şairlerin gazellerine yazdığı nazireler çok daha başarılıdır.

Namık Kemal'in sadece birer gazeline nazire yazdığı dönem şairleri de vardır. Bu şairler arasında Şinasi ayrı bir öneme sahiptir. Faik Memduh, Şem'i, Selim, Akif Paşa'ya yazdığı nazireler Namık Kemal için bir halkaya dahil olabilmenin ispatı nev'indendir.

Namık Kemal encümen şairlerinden olan Faik Memduh'un iki gazeline nazire yazar. Faik Memduh'un şiirlerinin de bir yenilik getirmekten ziyade klasik anlayışı devam ettirdiğini söylemek istiyoruz. Faik Memduh'un şiirlerinin dikkat çeken özelliği ahenkli ve akıcı bir dil kullanmış olmasidir:

Ey şeker leb maksadın efvahı söyletmek midir

Yoksa tûtî-i dil-i âgâhı söyletmek midir (sy. 438) midir?)

(Ey şeker dudaklı, maksadın ağızları söyletmek midir, yoksa uyanık gönül kuşunu söyletmek

Namık Kemal, şiirinde Faik Memduh'un söyleyiş akıcılığından yararlanır:

Nazdan kasdın dil-i gümrâhı söyletmek midir 
Yoksa derdinden dehân-1 âhı söyletmek midir (sy. 437)

(Naz yapmaktan amacın yolunu şaşırmış gönlü söyletmek midir, yoksa derdinden âh çeken ağzı söyletmek midir?)

Faik Memduh'un diğer gazeli de:

Benim kim beyt-i mâ'mur'-1 felek beyt-i metînimdir

Bakılsa kıt'a kıt'a arza şi'r-i nevzemînimdir (sy. 438)

(Beyt-i mâmur (semada bulunduğu söylenen ev ya da Kâbe) benim sağlam bir evimdir, arza kıta kıta bakılsa yeni bir tarzın şiiridir.)

matlalı şiiridir. Şairin sözünün İlahî olduğunun düşünülmesi divan şairleri tarafından dile getirilir. Şair, tüm kâinata buradan bakarak kâinatın şiirini yeniden yazmak ister. Şairin bu yeniden kâinat şiirini yazma düşüncesi Namık Kemal'i de etkiler. Tecelli düşüncesini ile sözün kıymetini gösterir:

Kelîm-i Tûr-1 feyz envâr-1 dâğ-1 âteşinimdir

Nihâl-i şu'legüster medd ü feryâd ü eninimdir (sy. 438)

(Feyzin Tur (Dağı)'daki sözleri ateşimin nurlu yarasıdır, ışık saçan fidan titreyiş, feryad ve ağlayıp sızlamalarımdır.)

Allah'ın Tur Dağı'na tecelli etmesi, aşkın en mükemmel halinin bir göstergesidir. Âşık ile maşuğun görüşme anıdır. Bu tecellide olmak isteyen her âşı ancak oradan saçan ışıkların açtı̆̆ 1 yaralar ile yetinmek zorundadır. Tecelli nuru âşığın ağlama ve inlemelerinin de nedenidir.

Şem'i'nin sevgilinin âşığı öldürme konusundaki istekli hali ile ilgili yazdığı gazelde, âşık kendisini öldürmek isteyen fakat utancından yapamayan sevgiliye giderek ölüme hazır olduğunu göstermek istediğini anlatır:

Âr edermiş beni öldürmeye ol sîm tenim

Varayın yalvarayın boynuma takıp kefenim (sy. 333)

(Gümüş tenli sevgili beni öldürmeye utanırmış, boynuma kefenimi takıp varıp yalvarayım.)

Namık Kemal hem Fuzuli hem de Şem'inin benzer gazeline yazdığı nazirede aşk ateşini konu edinir:

Nâr-1 aşka bir sipend-i 1ztırâb olmuş tenim

Târ ü pûd-i şu'ledendir rişte-i pîrâhenim (sy. 333)

(Tenim aşk ateşine 1zdırap tütsüsü olmuş, gömleğimin ipi ışığın arış ile argacıdır-dokumada enlemesine at1lan atk1-)

Şair Selim, divan şiirinin klasik anlatımına uygun bülbül ve gül mazmunlarını kullanır:

Biz bülbül-i muhrik dem-i gülzâr-1 firâkız

Âteş kesilir geçse sâbâ gülşenimizden (sy. 352)

(Biz yakıcı bir bülbülüz (ki) ayrılık gül bahçesinin nefesiyiz, sabah rüzgârı gül bahçemizden geçse ateş kesilir.)

Namık Kemal bu şiire sadece aynı ölçüde nazire yazar. Anlam olarak tecelli üzerinde durur:

Dil nâzır olur kûyine dâğ-1 tenimizden

Firdevs-i tecellâ görünür revzenimizden (sy. 352) 
(Tenimizin yarasından gönül mahallene bekçi olur, penceremizden tecelli cenneti görünür.)

Âkif Paşa aşk acısı ve aşk yarasını konu edinir. Aşkın verdiği hüzün gece karanlığı ile karışacak kadar koyudur. Ortalığı aydınlatan aşk yarasından çıkan 1şıktır. Bu mazmunlar divan şiirinde sıkça kullanılır. Âkif Paşa bu mazmunları tekrar etmekle yetinir.

Şeb midir bu yâ sevâd-1 âh-1 pinhânım mıdır

Şem'-i meclis şu'le-i dâğ-1 füruzânım mıdır (sy. 390) midır?)

(Bu akşam mıdır ya da gizli âhımın karaltısı mıdır, meclisin çırası parlayan yaranın ışığı

Namık Kemal tanzirinde mahşer günü insanları yakan ateşi kendi aşk yarasına benzetir. Cehennem ateşi de âhının verdiği ışıktır. Şair aşk acısını benzer bir tarzda ele alır.

Mihr-i âlemsûz-1 mahşer dâğ-1 pinhânım mıdır

Nâr-1 dûzah şu'le-i âh-i fürûzânım mıdır (sy. 390)

(Mahşerin cihanı yakan güneşi gizli yaram mıdır, cehennem ateşi parlayan âhımın 1şığıdır.)

Şinasi’nin âşığın aşkından kanlı göz yaşları gönlün aynasıdır, aşk ateşin akıcı rengi de sırça gibi parıldar:

Âb ü tâb-1 girye-i pür hûn bir meclâ iki

Gevher-i seyyal-i âteş gûn bir mînâ iki (sy. 312)

(Kan dolu göz yaşının parlaklığı bir, ayna iki; ateş renginin akıcı cevheri bir sırça iki.)

Namık Kemal, Şinasi'nin gazelini tanzirinde kapalı bir anlam kullanır. Kan dolu göz yaşının kaynağı gönüldür, gönlün yansıması ise göz yaşıdır:

Dilde mevc-i girye-i pürhûn bir mecrâ iki

Gûyya olmuş mey-i gülgûn bir mînâ iki (sy. 312)

(Kan dolu gözyaşı dalgası gönülde bir, cereyan ettiği yer iki; güya pembe içki bir sırça iki.)

\section{Sonuç}

19. yy. Türk şiiri için bir geçiş ve arayışlar dönemidir. Divan şiirinin eski gücünü kaybetmesi, Batı tarzı anlayışın şairler tarafından öğrenilmeye başlanması bu geçişi hızlandıran etkenlerdir. Encümen-i Şuara şairlerinin divan şiirine yeni bir ruh kazandırma ve eski günlerine döndürme amacı bu dönemde divan şiirine ilgiyi artırsa da yeni şiir tarzı karşısında devamı gelmez. Encümen şairlerinin bir araya gelmesinde ve bir şiir zevki oluşturmasında önemli bir isim olan Leskofçalı Galib Bey, divan şiirini canlandırma konusunda diğer şairlere öncülük eder. Ancak o da yeni tarz şiirden uzak kalamaz ve şiirde yeni tarzlar dener. Encümen şairlerinin şiirlerini toplulukta okuyan Namık Kemal, Leskofçalı Galib Bey'in oldukça tesiri altında kalır. Başta onun şiirleri olmak üzere gerek kendi dönemindeki şairlere gerekse divan şairlerinin şiirlerine nazireler yazar. Namık Kemal'in divan şiiri tarzında yazdığı şiirlerde kendi sesini duyuramaz. Genellikle nazirelerden oluşan şiirlerde şaire ait bir özgünlük yok denecek kadar azdır. Ancak bu şiirler, tekrardan ibaret, hissiz, başarısız şiirler de değildir. Namık Kemal'in şiirleri ve şiir anlayışı için oldukça önemli bir eğitim sürecidir.

Namık Kemal'in divan şiirleri yapılan araştırmalarda göz ardı edilmiş, genellikle yeni tarz şiirleri üzerinde durulmuştur. Bu çalışmada şairin divan şiirleri tek tek ele alınmamış olsa da nazireler üzerinden divan şiirindeki durumu ortaya konulmaya çalışılmıştır. Nazirecilik divan edebiyatı geleneğinde önemli bir yere sahiptir. Bir şairin başka şairlere olan hürmeti, kalıcı bir şöhret yakalayan 
şairlere yaklaşabilmek, üslubu ve edâsı beğenilen şairler gibi olma isteği, yenilik getiren şairlere olan ilgi, beğenilen şair gibi olabilme isteği gibi nedenlerle yazılan nazireler, şairlerin kendi tarzlarını oluşturmalarında etkili olur. Namık Kemal'in divan tarzı şiirlerinin taklit olarak görülmesi ya da şiirlerin çoğunun nazirelerden oluşmasının eleştirilmesini şaire yapılan bir haksızlık olarak görüyoruz. Namık Kemal, nazirelerinde nazire yazdığı şairlerin üslubunu, edâsını yakalayabilmiş, hatta onların önüne geçebilecek kadar başarılı şiirler de yazar.

Namık Kemal'in toplamda 315 adet gazelinin 183'ünün nazire olması oran olarak oldukça yüksektir. Bu şiirler içerisinde Leskofçalı Galib Bey'in şiirleri toplamda 52 nazire ile ilk sırayı almaktadır. Leskofçalı Galib Bey'den sonra ise Hersekli Ârif Hikmet Bey 32 şiirine yazılan nazireler ile ikinci sırada yer alır. Bu şairlerin encümen-i şuara'nın toplanmasında ve bir şiir zevki oluşturmadaki rolleri düşünüldüğünde Namık Kemal' in bu şairlere nazire yazması da anlaşılabilir.

16. yy.'dan 19. yy.'a kadar divan şiirinde şöhret bulmuş, tarzı ile adından bahsettirmiş şairler, özellikle de ahenk konusunda usta isimler, Namık Kemal'in ilgisini çeker. Divan şiirinin Şeyh Galip'le geldiği noktaya tekrar bağlanması isteği bu döneme olan ilgiyi arttırır. Namık Kemal bu yüzyıllar arasındaki şairlerden özellikle ahenk unsurlarını ön plana çıkartan, düşünce ağırlıklı ve şiire yenilik getiren, kendine has bir tarz geliştiren şairleri tercih eder. Fuzuli, Şeyhülislam Yahya, Nedim, Naili, Fehim bu özellikleri ile bilinen şairlerdir. Namık Kemal'in bu şairlerin şiirlerine nazire yazması şiir anlayışını göstermesi bakımından da önemlidir. Gerek encümen şairlerinin gerekse Namık Kemal'in bu şairlere nazire yazması, divan şiirinin bu şairlerin bıraktığı noktaya çıkartılmasını amaçlamaktadır.

Namık Kemal'in 16. - 19. yy.'lar arasında şöhret bulmuş şairlere yazdığı nazirelerde başarılı olduğunu söylemek oldukça zordur. Ancak şairin kendisini bulmasında ve şiir zevkini geliştirmesinde bu dönem şairlerinin etkisi açıkça görülür. Namık Kemal, bu nazirelerinde bir arayış içerisindedir. Divan şiirini bireysellikten toplumsallığa çıkartan, soyut ifadeler yerine daha somut bir anlatımla kendisini gösterir. Divan şiirinde aşk ve aşk acısı farklı boyutlarda ele alınırken Namık Kemal, aşk acısını da genelleştirir. Bireysel ızdırap yerine bu 1zdırabın kâinattaki tüm varlığı nasıl etkilediği şairin asıl odak noktası olur. Özellikle somut bir anlatımın tercih edilmesi, soyutlamalardan ve aşırı mazmunlardan kaçınarak divan şiirini daha gözle görünür, akla yatkın bir forma dönüştürmeye çalışır. Bu açıdan bakıldığında Namık Kemal'in yazdığı nazireler sadece bir şekil ve anlam tekrarından çok, eski tarz üzerinde değişimin ayak seslerinin ortaya konulmasıdır.

19. yy. şairlerinin çoğu divan şiirini tekrar ayağa kaldırma düşüncesindedir. Özellikle encümen toplantıları bu amaca yönelik olarak yapılır. Leskofçalı Galib Bey'in bu toplantılardaki tutumu ve şiir anlayışının diğer şairlere örnek oluşturması kısa bir süre varlığını devam ettiren topluluğun en önemli işlevidir. Namık Kemal, bu dönem şairleri arasında en fazla nazireyi Galip Bey'in şiirlerine yazar. Bu nazirelerde şair, yeni şiir için önemli adımlar atar. Âşık ve sevgili arasındaki ilişkiyi çoğu zaman İlahî aşka bağlayan şair, Hz. Musa ve Tur Dağı hadisesine çok sık telmihte bulunur. Allah'ın yeryüzüne tecelli ettiği yer ve zaman olarak bilinen Tur Dağı hadisesi, Allah'ın varlığının somut bir göstergesi olarak ele alınır. Bu bakış açısı, Tanzimat döneminde Allah'ın varlığına delil aranması ve aklın ön planda tutulmasının bir bakıma zeminini oluşturur.

Encümen-i Şuara şairlerinin şiirlerindeki coşkun söyleyiş tarzı, Namık Kemal'in de belirgin üslubu haline gelir. Leskofçalı Galib Bey'in divan mazmunlarını farklılaştırması ve bağlamlarından kopartarak yeni anlamlar yüklemesi, Hersekli Ârif Hikmet Bey'in sembolizmi çağrıştıran şiirleri Namık Kemal'in şairliğinin çok geniş bir yelpazede gelişmesini sağlar.

Namık Kemal, yeni şiirin öncü şairlerinden olsa da divan şiir tarzında farklı bir yere sahiptir. Yazdığı nazireler, onu divan şairi olma yolunda çok ileriye götüremese de şiir estetiği ve bakış açısının oluşmasında önemli bir rol oynar. 


\section{KAYNAKÇA}

Akalın, N. (1997). "Namık Kemal'in Eski Türk Edebiyatına Bakışı", Dergâh, Edebiyat, Sanat, Kültür Dergisi, C. 8, S. 94, Aralık, ss. 14-17.

Akımsar, B. (1961). Namık Kemal, Hayatı, Kişiliŭi, Mücadelesi, Eserleri, İzmir: Kovan Kitabevi.

Akyüz, K. (1982). “Tanzimat Devri-_iir”, Modern Türk Edebiyatının Ana Çizgileri (1860-1923) I, 4.bs, Ankara: Mas Matbaacılik ve Aksesuvarları, ss. 23-25.

Akyüz, K. (1986). "Namık Kemal”, Batı Tesirinde Türk Şiiri Antolojisi, 4.bs., İstanbul: İnkılâp Kitabevi, ss. 52-61.

Akyüz, K. (2017). Batı Tesirinde Türk Şiiri Antolojisi, İnkılap Kitabevi, İstanbul.

Alper, K. (2014). "Namık Kemal'den Ahmet Hamdi Tanpınar'a Eski Yeni Tenkidi”, Turkısh Studies Language and Literature, Volume 9/6, p. 611-624.

Ayaz, H. (1995). Tanzimat Şiirinde Metafizik Konular (Şinasi, Ziya Paşa, Namık Kemal, Recaizade M. Ekrem, Abdülhak Hâmid, Muallim Nâcî), Basılmamı_ Doktora Tezi, Elazığ: Fırat Üniversitesi, Sosyal Bilimler Enstitüsü, Türk Dili ve Edebiyatı Anabilim Dalı, s. 276.

Aydın A. (2011). “Namık Kemal'i Victor Hugo'ya Götüren Etkenler”, Turkish Studies International Periodical For the Languages, Literature and History of Turkish or Turkic, Vol. 6/3, Summer, pp. 197- 204.

Aydoğan, B. (1987). Namık Kemal'in Eserlerinde Sanat ve Edebiyat Görüşleri, Basılmamış Yüksek Lisans Tezi, Ankara: Ankara Üniversitesi, Sosyal Bilimler Enstitüsü.

Ayverdi, İ.(2016). Misalli Büyük Türkçe Sözlük. İstanbul: Kubbealtı Yayınları.

Azamat, N. (2007). TDV İslam Ansiklopedisi, 33. Cild, İstanbul, TDV Yayınları.

Banarlı, N. S. (1983). "Ekrem - Hamid - Sezai Mektebi ve Türk Edebiyatında Sanat İçin Sanat Temayülleri”, Resimli Türk Edebiyatı Tarihi, 2.bs., İstanbul: Milli Eğitim Basımevi, C. 2, ss. 915-916.

Banarl1, N. S. (1983). "Namık Kemal (1840-1888)", Resimli Türk Edebiyatı Tarihi, 2.bs., İstanbul: Milli Eğitim Basımevi, C. 2, ss. 879- 914.

Banarlı, N. S. (1983). "Şinâsî - Ziya Paşa - Namık Kemal Mektebi ve Türk Edebiyatı / Cemiyet İçin Sanat Hareketleri”, Resimli Türk Edebiyatı Tarihi, 2.bs., İstanbul: Milli Eğitim Basımevi, C. 2, ss. 858-859.

Bilgegil, M. K. (1972). Harabat Karşısında Namık Kemal: Namık Kemal'in Eski Edebiyata İtirazlarl, 1.bs., İstanbul: İrfan Yayınevi, s. 303.

Bolayır, Kemal-zade A. E. (1908). Rûh-i Kemal, İstanbul: Mehmed Bey Matbaas1.

Çalık, E. (1991). "Namık Kemal'in Edebiyat Hakkındaki Görüşleri”, İslâmî Edebiyat, S. 14, EkimKasım-Aralık, ss. 21-22; Komisyon (1993). DoğumununYüz ellinci Yılında Namık Kemal, Ankara: Atatürk Kültür, Dil ve Tarih Yüksek Kurumu Atatürk Kültür Merkezi Yayını - Sayı $67, \mathrm{XV}+280$.

Devellioğlu, F. (2013). Osmanlıca - Türkçe Ansiklopedik Lûgat. Ankara: Aydın Kitabevi Yayınları.

Dilmen, İ. N.(118). Târih-i Edebiyyat-1 Osmâniyye, C. II, İst. Matbaa-i Âmire. 
Dizdaroğlu, H. (1954). Namık Kemal, Hayatı, Sanatı, Eserleri, İstanbul: Varlık Yayınları.

Doğan, M. N. (1996). Fuzuli'nin Poetikası, İlmi Araştırmalar 2, İstanbul.

Durusoy A. (2012), Vahdet, TDV İslam Ansiklopedisi, 42. Cild, 430-431.

Ebuzziya Tevfik (1908). Kemal Bey'in Terceme-i Hali, İstanbul: Ebuzziya Matbaası, İstanbul.

Ekiz, O. N. (1984). Namık Kemal, Hayatı, Sanatı, Eserleri, İstanbul: Gökşin Yayınları.

Enginün İ. (2007). Yeni Türk Edebiyatı Tanzimat'tan Cumhuriyet'e (1839-1923), Dergâh yayınları.

Ercilasun, B. (1989). "Namık Kemal'in Şiirleri Hakkında”, Gazi Ĕ̆itim Fakültesi Dergisi, S. 1, Ankara.

Ergun, S. N. (2018), Namık Kemal'in Hayatı ve Şiirleri, Historia Yayınları, İstanbul.

Ergüç, A. (1959). Namık Kemal, Konya: Şahap Kitabevi.

Ersoylu, H. (2003). “Hürriyet Kasidesi'nin Metin Örgüsü ve Bunun Namık Kemal'in Yeni Şiirindeki İzleri”, Türk Dili Araştırmaları Yıllı̆̆ $ı$ Belleten, C. 1, Ankara, ss. 23-38.

Ertaylan, İ. H. (1932). Namık Kemal, İstanbul: Kanaat Kütüphanesi.

Ertem, A. (1957). Namık Kemal'in Şiirleri, Yeni Matbaa, İstanbul.

Gariper, C. (2005). "Yenileşmenin Başlangıcı ve Öncüleri / Şinasi - Namık Kemal - Ziya Paşa Ahmet Midhat Efendi", Yeni Türk Edebiyatı El Kitabı (1839-2000), [Ramazan Korkmaz (ed.) - Hülya Argunşah - Ali İhsan Kolcu - Ayşenur Külahlığlu İslam - Cafer Gariper Osman Gündüz - Tarık Özcan], 2.bs., Ankara: Grafiker Yayınları, ss. 41-80.

Göçgün, Ö. (1987). Namık Kemal, Ankara: Kültür ve Turizm Bakanlığı Yayınları.

Göçgün, Ö. (1991). “Namık Kemal'in Yazdığı İlk Beyit”, Türk Edebiyatı Araştırmaları II, Konya: Selçuk Üniversitesi Yayınları, ss. 202-204: “...Namık Kemal, henüz 12 yaşında iken Kars’ta ilk beytini yazd1...".

Göçgün, Ö. (1999). Namık Kemal'in Şairliği ve Bütün Şiirleri, 1.bs., Ankara: Atatürk Kültür Merkezi Başkanlığı Yayınları, XCIV+468 s..

Göçgün, Ö. (2009). Edebiyat ve Kültür Dünyamızda Namık Kemal, Hayatı, Eserleri, Edebî Kişiliği ve Eserlerinden Açıklamalı Seçmeler, 1.bs., Ankara: Atatürk Kültür Merkezi Yayınları, s. 222.

Gültekin, İ. (2013). Nâbî’nin İki Gazelinde Kalb'den Anlama Giden Yol, A. Ü. Türkiyat Araştırmaları Enstitüsü Dergisi [TAED] 49, Erzurum.

Gündüz, O. (2002). "Namık Kemal'in Şiirlerinde Fonetik Unsurlar ve Kişi Zamirlerinin Kullanılışı”, Bilig / Türk Dünyası Sosyal Bilimler Dergisi, No: 20, ss. 125-139.

Gürlek, D. (1988). Namık Kemal, Hayatı - Sanatı - Eserleri, İstanbul: Boğaziçi Yayınevi.

Hersekli Ârif Hikmet (1334), Divân, Âsâr-1 Müfîde Kütüphânesi-Matbaa-i Âmire, İstanbul.

Hökelekli, H. (2000). “İdrak”, TDV İslam Ansiklopedisi, 21. C., 477-478.

Kaplan, M. (1948). Namık Kemal Hayatı ve Eserleri, İstanbul: İstanbul Üniversitesi Edebiyat Fakültesi Yayınları, s. 240.

Kaplan, M., Enginün İ., Emil, B (1978). Yeni Türk Edebiyatı Antolojisi II, 1865 - 1876, İstanbul Üniv. Edebiyat Fak. Yayınevi, İstanbul. 
Kaplan, M. (1981). "Hürriyet Kasidesi”, Tanzimat'tan Cumhuriyet'e Şiir Tahlilleri, 7.bs., İstanbul: Dergâh Yayınları, C. 1, ss. 37-45.

Kaplan, M. (2006). Türk Edebiyatı Üzerinde Araştırmalar I, Dergâh yayınları, İstanbul, 8.b.

Kara, E. (1988). Namık Kemal'in Eserlerinde Benzetme Unsurlarl, Basılmamı_Bilimde Uzmanlık Tezi, İstanbul: İstanbul Üniversitesi, Sosyal Bilimler Enstitüsü, s. 737.

Kaya, T. (2019). "Namık Kemal'in Bilinmeyen Bir Şiiri”, Turkısh Studies Language and Literature, Volume 14 Issue 2, p. 611-624.

Kemal, N. (1989), Tercüme-i Hâl-i Emir Nevruz Mukaddime, Namık Kemal'in Türk Dili ve Edebiyatı Üzerine Görüşleri ve Yazıları, (haz. Kazım Yetiş), İstanbul Üniversitesi Edebiyat Fak. Yay. İstanbul.

Kemaleddin Şükrü (1931). Namık Kemal, İstanbul: Kanaat Kütüphanesi.

Kısakürek, N. F. (1940). Doğumunun Yüzüncü Yıl Dönümü Dolayısıyle Namık Kemal Şahsı-Eseri - Tesiri, Ankara: Türk Dil Kurumu Yayınları, , 6+[4]+316+LXXXVIII s.+7 adet resim.

Kısakürek, N. F. (1940). Doğumunun Yüzüncü Yıl Dönümü Dolayısıyle Namık Kemal, Şahsı, Eseri, Tesiri, TDK Yay., Ankara 1940.

Kısakürek, N. F. (2009), Namık Kemal, Şahsı-Eseri-Tesiri, Ankara, TDK.

Kocakaplan, İ. (1999). Namık Kemal, İstanbul: Timaş Yayınları, s. 150.

Kocatürk, V. M. (1955). Namık Kemal'in Hayatı, İstanbul: Buluş Yayınevi.

Koçin, A. (2009). Divan Şiirinde Hz. İsa, Sakarya Üniversitesi İlahîyat Fakültesi Dergisi, S.19, s.69104.

Kolcu, A. İ. (2005). "Yenileşmenin İkinci Kuşağı / Ekrem-Hamid-Sezai Mektebi”, Yeni Türk Edebiyatı El Kitabı (1839-2000), [Ramazan Korkmaz (ed.) - Hülya Argunşah - Ali İhsan Kolcu - Ayşenur Külahlıoğlu İslam - Cafer Gariper - Osman Gündüz - Tarık Özcan], 2.bs., Ankara: Grafiker Yayınlar1, ss. 81-108.

Kolcu, A. İ. (2010). Namık Kemal' in Poetikası, 1.bs., Erzurum: Salkımsöğüt Yayınevi, s. 96.

Komisyon (1942). Namık Kemal Hakkında, İstanbul: Dil ve Tarih-Coğrafya Fakültesi Türk Dili ve Edebiyatı Enstitüsü Neşriyat1: 2, Vakit Matbaas1.

Korkmaz, R. (2005). "Yeni Türk Edebiyatına Giriş / Hazırlık Dönemi ve İlk Denemeler”, Yeni Türk Edebiyatı El Kitabı (1839-2000), [Ramazan Korkmaz (ed.) - Hülya Argunşah - Ali İhsan Kolcu - Ayşenur Külahlığlu İslam - Cafer Gariper -Osman Gündüz - Tarık Özcan], 2.bs., Ankara: Grafiker Yayınları, ss. 13-40.

Köksal, Y. (1957). Namık Kemal, İstanbul: Şevket Ünsal Matbaası.

Kurt, H. (2001). Namık Kemal'de Din ve Sosyal Felsefe, Basılmamı_Yüksek Lisans Tezi, Ankara: Ankara Üniversitesi, Sosyal Bilimler Enstitüsü, Temel İslam Bilimleri Anabilim Dalı, $\mathrm{V}+128$.

Kutlar, F. S. (2006). Mustafa Sâmi Bey, TDV İslam Ansiklopedisi, 31.C., İstanbul.

Namık Kemal (1989). Mukaddime-i Celal, Namık Kemal'in Türk Dili ve Edebiyatı Üzerine Görüşleri ve Yazıları, (hz. Kazım Yetiş), İstanbul, İstanbul Üniversitesi Edebiyat Fakültesi Yayınları.

Onan, Prof. N. H. (1951). "Nâmık Kemal'in Tâlim-i Edebiyat Üzerine Bir Risalesi”, Ankara. 
Öngören, R. (2000) “İbrahim b. Edhem”, İstanbul, Türkiye İslam Ansiklopedisi, Diyanet Vakfı Yayınları.

Özgül, K. (2015). Şiirin Hazanında Gazel Dökenler II - Hersekli Ârif Hikmet Bey, İstanbul, Kitabevi.

Özgül, K. (2015). Şiirin Hazanında Gazel Dökenler- II Hersekli Ârif Hikmet Bey, Kitabevi.

Özgül, M. K. (2014), Kemâl'le İhtimal Yahut Nâmık Kemal'in Şiirine Tersten Bakmak, İstanbul, Dergâh Yayınları.

Pala İ. (1997). “Devlet Olmanın Beş Şartı”, Şi’r-i Kadîm / Şiir Şerhleri,İstanbul: Ötüken, ss. 100102.

Parlatır İ. vd. (2006), Tanzimat Edebiyatı, Akçağ yayınları, Ankara.

Parlatır, İ. (1988). "Namık Kemal'in Lâzımsa Redifli Gazelleri ve Nazireleri”, Ölümünün 100. Yılında Namık Kemal, İstanbul: Marmara Üniversitesi Yayınları, ss. 161-183.

Parlatır, İ. (1989). "Namık Kemal'in Edebiyatımıza Getirdiği Yeni Değerler”, Gazi Eğitim Fakültesi Dergisi, C. V, S. 1, Ankara, ss. 37-46.

Parlatır, İ. (1992). "XIX. Yüzyıl Yeni Türk Şiiri / Tanzimat'ın kinci Kuşağı”, Türk Dili, Ayllk Dil Dergisi IV (Çağdaş Türk Şiiri), S. 481-482 / Ocak - Şubat - Mart, ss. 17-29.

Parlatır, İ. (1992). “XIX. Yüzyıl Yeni Türk Şiiri / Tanzimat'ın Birinci Kuşağı”, Türk Dili, Aylık Dil Dergisi IV (ÇağdaşTürk Şiiri), S. 481-482 / Ocak - Şubat - Mart, ss. 10-17.

Su, H. - Karadeniz, A. (ed.) (2012). Namık Kemal, Tekirdağ: Namık Kemal Üniversitesi Yayını, 448 s. Namık Kemal, Hayatı ve Eserleri], Kahire: Câmi'atü Ayn şems, Külliyyetü'1-Âdâb (Basılmamı_ Master Tezi), 190 s. (Edebiyat Fak. Kütüb. No: 17673-17674, Yeni No: 459460).

Sungurhan-Eyduran, A. (2006). Şem'. Türk Dünyası Edebiyat Kavramları ve Terimleri Sözlüğü. (c. 5, ss. 392-393). Ankara: Atatürk Kültür Merkezi Yayınları.

Süleyman Nazif (1922). Namık Kemal, İstanbul: İkdam Matbaası.

Süleyman Nazif (1925). İki Dost (Namık Kemal - Ziya Paşa), İstanbul: Kanaat Kütüphanesi.

Süleyman Nazif (2011). Namık Kemal [Haz. Mehmet Samsakçı], İstanbul: Kitabevi Yayınları, $\mathrm{XXI}+177 \mathrm{~s}$.

Şahin, C. (2017). "Namık Kemal ve Beşir Fuad'daki Vıctor Hugo Portresi”, Turkısh Studies Language and Literature, Volume 12/30, p. 415-431.

Şengül, A. (2000). "Yeni İnsan Anlayışı Çerçevesinde Namık Kemal'in Hürriyet Kasidesi'ne Genel Bir Bakış”, Afyon Kocatepe Üniversitesi Sosyal Bilimler Enstitüsü Sosyal Bilimler, C. II, S. 1, Nisan, ss. 25-34.

Tanpınar A. H. (2009), 19. Asır Türk Edebiyatı Tarihi, 5. bs., Çağlayan Kitabevi, İstanbul, s. 252253.

Tanpınar, A. H. (1982). "Namık Kemal”, 19'uncu Asır Türk Edebiyatı Tarihi, 5.bs., İstanbul: Çağlayan Kitabevi, ss. 342-444.

Tansel, F. A. (2005). Hususi Mektuplarına Göre Namık Kemal ve Abdülhak Hamid, Ankara: Akçağ Yayınlar1.

Tarlan, A. N. (1985). Fuzuli Divanı Şerhi, sy. 457. 
Tavukçu, O. K. (2011). Namık Kemal, 1.bs., Ankara: Kültür ve Turizm Bakanlığı Yayınları.

Toros, T. (1998). Türk Edebiyatından Altı Renkli Portre: Namık Kemal, Mehmet Akif, Abdülhak Hamid, İbnülemin, Yahya Kemal, Abdülhak Şinasi, İstanbul: İsis Yayıncılık.

Turgut, C. Ö. (2010). "Namık Kemal'in Vaveylâ Adlı Şiirinde Vatan Anlayışı", Prof. Dr. Bilge Ercilasun Armă̆anı, Ankara: Pegem Akademi Yayınları, ss. 315-322.

Uçman A. (2006). "Namık Kemal", Tanzimat Edebiyatı, (Haz.: Abdullah Uçman - Ahmet Bican Ercilasun - İnci Enginün - İsmail Parlatır - Nurullah Çetin - Zeynep Kerman), 1.bs., Ankara: Akçağ Yayınları, ss. 201-288.

Uçman, A. (2007). "Namık Kemal'in Divan Edebiyatına İtirazları", Kitap-lık, Aylık Edebiyat Dergisi [Dosya: Eski Edebiyata Yeni Yorumlar], S. 107, Temmuz - Ağustos, ss. 73-77.

Uludağ, S. (1996). Tasavvuf Terimleri Sözlüğü, İstanbul: Marifet Yay.

Üstünova, M. (1992). “Divan Edebiyatının Tanzimat Birinci Dönem Sanatç1ları Üzerindeki Etkileri”, Uludă̆ Üniversitesi, Ĕ̆itim Fakültesi Dergisi, C. VII, S. 2, Bursa, ss. 141-150.

Üzgör, T. (1995). Fehim-i Kadîm, İslam Ansiklopedisi, TDV Yayınları, 1995.

Yavuz Y. Ş. (1991), Arş, TDV İslam Ansiklopedisi, 3.C., İstanbul.

Yazıc1, T. (1993) “Câm-1 Cem”, İstanbul, Türkiye İslam Ansiklopedisi, Diyanet Vakfı Yayınları.

Yetiş, K. (1989). Namık Kemal'in Türk Dili ve Edebiyatı Üzerine Görüşleri ve Yazıları, İstanbul Üniversitesi Edebiyat Fakültesi yayınları, İstanbul.

Yetiş, K. (1989). Namık Kemal'in Türk Dili ve Edebiyatı Üzerine Görüşleri ve Yazıları, İstanbul: İstanbul Üniversitesi Edebiyat Fakültesi Yayınları.

Yetiş, K. (1993). "Edebiyat Nazariyesi Kitaplarında Namık Kemal'in Eserlerinin Örnek Olarak Değerlendirilişı”, Doğumunun Yüz ellinci Yılında Namık Kemal, Ankara: Atatürk Külttür, Dil ve Tarih Yüksek Kurumu Atatürk Kültür Merkezi Yayını - Sayı 67, ss. 117 - 136.

Yıldı,, S. (2006). “Tanzimat'1n Birinci Nesli”, Tanzimat Dönemi Edebiyatı, 2.bs., İstanbul: Nobel Yayın Dağıtım, s. 121.

Yıldız, S. (2006). “Tanzimat'ın İkinci Nesli”, Tanzimat Dönemi Edebiyatı, 2.bs., İstanbul: Nobel Yayın Dağıtım, s. 139-141.

http://www.turkedebiyatiisimlersozlugu.com/index.php?sayfa=detay\&detay=2462, Erişim Tarihi: 28.08.2019

https://edebiyatvesanatakademisi.com/divan-siiri-ve-sairler/seyhulislam-yahya-hayati-ve-edebikisiligi-1020.aspx, Erişim Tarihi: 28.08.2019

http://www.turkedebiyatiisimlersozlugu.com/index.php?sayfa=detay\&detay=572), Erişim Tarihi: 28.08.2019

http://www. turkedebiyatiisimlersozlugu.com/index.php?sayfa=detay\&detay=1900), Erişim Tarihi: 28.08.2019 